\title{
Chapter 11 \\ Assessing Potassium Mass Balances in Different Countries and Scales
}

\author{
Kaushik Majumdar, Robert M. Norton, T. Scott Murrell, Fernando García, \\ Shamie Zingore, Luís Ignácio Prochnow, Mirasol Pampolino, Hakim Boulal, \\ Sudarshan Dutta, Eros Francisco, Mei Shih Tan, Ping He, V. K. Singh, and \\ Thomas Oberthür
}

K. Majumdar $(\bowtie) \cdot S$. Zingore $\cdot$ S. Dutta $\cdot$ T. Oberthür African Plant Nutrition Institute and Mohammed VI Polytechnic University, Ben Guerir, Morocco

e-mail: k.majumdar@apni.net; s.zingore@apni.net; s.dutta@apni.net; t.oberthur@apni.net

R. M. Norton

Faculty of Veterinary \& Agricultural Sciences, The University of Melbourne, Parkville, VIC, Australia

e-mail: rnorton@unimelb.edu.au

T. S. Murrell

African Plant Nutrition Institute and Mohammed VI Polytechnic University, Ben Guerir, Morocco

Department of Agronomy, Purdue University, West Lafayette, IN, USA

e-mail: s.murrell@apni.net

F. García

Balcarce, Argentina

L. I. Prochnow · E. Francisco

Plant Nutrition Science and Technology, Piracicaba, SP, Brazil

e-mail: LProchnow@npct.com.br

M. Pampolino

Calabarzon, Philippines

H. Boulal

African Plant Nutrition Institute, Settat, Morocco

e-mail: h.boulal@apni.net

M. S. Tan

Dell Technologies, Pulau Pinang, Malaysia

P. He

Institute of Agricultural Resources and Regional Planning, Chinese Academy of Agricultural Sciences, Beijing, China

V. K. Singh

Division of Agronomy, ICAR-Indian Agricultural Research Institute, New Delhi, India

(C) The Author(s) 2021

T. S. Murrell et al. (eds.), Improving Potassium Recommendations for Agricultural

Crops, https://doi.org/10.1007/978-3-030-59197-7_11 


\begin{abstract}
Estimating nutrient mass balances using information on nutrient additions and removals generates useful, practical information on the nutrient status of a soil or area. A negative input-output balance of nutrients in the soil results when the crop nutrient removal and nutrient losses to other sinks become higher than the nutrient inputs into the system. Potassium (K) input-output balance varies among regions that have different climates, soil types, cropping systems, and cropping intensity. This chapter illustrates the farm-gate $\mathrm{K}$ balances in major production areas of the world and their impacts on native $\mathrm{K}$ fertility and crop yields. On-farm and on-station research examples show significant negative $\mathrm{K}$ balances in South Asia and Sub-Saharan Africa, while China, the USA, Brazil, and countries of the Latin America Southern Cone highlighted continued requirement of location-specific K application to maintain crop yields and soil $\mathrm{K}$ fertility status at optimum levels.
\end{abstract}

\title{
11.1 Concepts of Soil Nutrient Balance
}

Soil nutrient balance is an account of the total inputs and outputs of a particular nutrient in an agroecosystem (NAL 2020). Soil nutrient balance is the principle of mass balance applied to crop nutrients. Mass balance accounts for the matter entering, present in, and leaving a system. Öborn et al. (2003) separated soil nutrient balances into three categories: farm-gate, field, and farm-system budgets. These types of balances compare nutrient imports to nutrient exports. Farm-gate balances are not limited to farms but can be calculated at a variety of scales, depending on the data available. In this chapter, we focus on $\mathrm{K}$ farm-gate balances at the state/province and national levels across major production areas of the world.

\subsubsection{Potassium Removal and Use for Different Cropping Systems and Geopolitical Boundaries}

Because of its economic and environmental importance, there is increasing interest in developing ways to evaluate the efficiency and effectiveness of fertilizer use on farms, as well as at regional and national scales. Partial nutrient balance (PNB) is, for a given nutrient, the sum of outputs divided by the sum of inputs (Table 11.1). Partial factor productivity (PFP) is, for a given nutrient, biomass yield divided by the sum of inputs. Both can provide some guidance on system-level efficiency relative to nutrient use. These two metrics have been used to describe system performance in relation to nutrient use at continental (Ladha et al. 2003), national (Lassaletta et al. 2014), regional (Edis et al. 2012), and at farm-gate (Gourley et al. 2012) scales, and by industry (McLaughlin et al. 1992). Although trends in N and P use have been presented (Zhang et al. 2015; Lassaletta et al. 2014), there are few reports of these trends for $\mathrm{K}$ other than Fixen et al. (2015). This chapter seeks to 
Table 11.1 Commonly used K use efficiency metrics and typical ranges for cereal crops

\begin{tabular}{|c|c|c|}
\hline $\begin{array}{l}\text { Potassium use efficiency abbreviation, calculations } \\
\text { (calc), and units }{ }^{\mathrm{a}}\end{array}$ & Equation $^{\mathrm{b}}$ & $\begin{array}{l}\text { Typical ranges for } \\
\text { cereals }^{c}\end{array}$ \\
\hline $\begin{array}{l}\mathrm{PFP}_{\mathrm{K}} \text { : partial factor productivity } \\
\text { calc: biomass yield/sum of } \mathrm{K} \text { inputs } \\
\text { units: kg biomass }(\mathrm{kg} \mathrm{K})^{-1}\end{array}$ & $Y / I_{\mathrm{K}}$ & $75-200$ \\
\hline $\begin{array}{l}\mathrm{PNB}_{\mathrm{K}} \text { : partial nutrient balance } \\
\text { calc: sum of } \mathrm{K} \text { outputs/sum of } \mathrm{K} \text { inputs } \\
\text { units: unitless }\end{array}$ & $O_{\mathrm{K}} / I_{\mathrm{K}}$ & $0.7-0.9$ \\
\hline $\begin{array}{l}\mathrm{PNBI}_{\mathrm{K}} \text { : partial nutrient balance intensity } \\
\text { calc: sum of } \mathrm{K} \text { inputs }- \text { sum of } \mathrm{K} \text { outputs } \\
\text { units: } \mathrm{kg} \mathrm{K} \mathrm{ha}^{-1} \text { or } \mathrm{kg} \mathrm{K}_{2} \mathrm{O} \mathrm{ha}\end{array}$ & $I_{\mathrm{K}}-O_{\mathrm{K}}$ & - \\
\hline $\begin{array}{l}\mathrm{AE}_{\mathrm{K}} \text { : agronomic efficiency } \\
\text { calc: increase in biomass yield/sum of } \mathrm{K} \text { inputs } \\
\text { units: kg biomass (kg K input) }\end{array}$ & $\begin{array}{l}\left(Y_{+\mathrm{K}}-Y_{-\mathrm{K}}\right) / \\
I_{\mathrm{K}}\end{array}$ & $8-20$ \\
\hline $\begin{array}{l}\mathrm{RE}_{\mathrm{K}}: \text { recovery efficiency } \\
\text { calc: increase in } \mathrm{K} \text { uptake/sum of } \mathrm{K} \text { inputs } \\
\text { units: unitless }\end{array}$ & $\begin{array}{l}\left(U_{+\mathrm{K}}-U_{-}\right. \\
\mathrm{K}) / I_{\mathrm{K}}\end{array}$ & $0.3-0.5$ \\
\hline
\end{tabular}

${ }^{\mathrm{a}}$ Generalized from Dobermann (2007) to apply to all inputs and outputs in the $\mathrm{K}$ cycle

${ }^{\mathrm{b}} Y$, biomass yield; $I_{\mathrm{K}}$, sum of $\mathrm{K}$ inputs; $O_{\mathrm{K}}$, sum of $\mathrm{K}$ outputs; $Y_{+\mathrm{K}}$, biomass yield where $\mathrm{K}$ was added; $Y_{-\mathrm{K}}$, biomass yield where $\mathrm{K}$ was not added; $U_{+\mathrm{K}}$, plant $\mathrm{K}$ uptake where $\mathrm{K}$ was added; $U_{-\mathrm{K}}$, plant $\mathrm{K}$ uptake where $\mathrm{K}$ was not added

${ }^{\mathrm{c}}$ Fixen et al. (2015)

provide a selection of case studies from different regions and at different scales on the removal and use of $\mathrm{K}$ within farming systems.

\subsubsection{Metrics for Nutrient Use Efficiency}

Nutrient use efficiency (NUE) is an evaluation of crop performance based on the quantity of a given nutrient input. Nutrient use efficiency is a broad term and is quantified in various ways by various metrics. Table 11.1 shows a selection of nutrient use efficiency terms and their definitions. Partial nutrient balance and PFP have already been discussed. Partial nutrient balance intensity (PNBI) is, for a given nutrient, the sum of inputs minus the sum of outputs on an area basis. Where data or estimates exist, outputs and inputs can include all of those in the $\mathrm{K}$ cycle (Fig. 1.2, Chap. 1). Agronomic efficiency (AE) is, for a given nutrient, the increase in biomass yield divided by the associated sum of inputs. Positive returns to fertilizer investments are indicated when AE is greater than the ratio of fertilizer price to crop price. Recovery efficiency (RE) is, for a given nutrient, the increase in uptake divided by the associated sum of inputs. Recovery efficiency ranges from 0 to 1 , with 1 interpreted as complete uptake of all of the nutrients applied. Of these metrics, PNB and PNBI are most often used to evaluate soil nutrient balances.

At the field, farm, or region scale, $\mathrm{PNB}_{\mathrm{K}}$ and $\mathrm{PNBI}_{\mathrm{K}}$ are often calculated using only harvested plant $\mathrm{K}$ and fertilizer $\mathrm{K}$ (inorganic and organic). Calculating $\mathrm{PNB}_{\mathrm{K}}$ 
and $\mathrm{PNBI}_{\mathrm{K}}$ with just these data is widely performed, but only indicates the fate of harvest nutrients and does not consider other transfer or retention fates. Partial nutrient balance has been recommended by the International Fertilizer Association (IFA 2020), the EU Nitrogen Expert Panel (2015), and the Global Partnership on Nutrient Management (Norton et al. 2015) as the most appropriate measure of nutrient use efficiency because data are generally available at farm and national levels from which it can be calculated.

In the context of $\mathrm{K}$, when the sum of $\mathrm{K}$ outputs equals the sum of $\mathrm{K}$ inputs, $\mathrm{PNB}_{\mathrm{K}}=1$ and $\mathrm{PNBI}_{\mathrm{K}}=0$. When more $\mathrm{K}$ is added than removed, $\mathrm{PNB}_{\mathrm{K}}<1$ and $\mathrm{PNBI}_{\mathrm{K}}>0$ (positive). The nutrient not removed can either be stored in the soil and/or flow through to the environment. When more $\mathrm{K}$ is removed than supplied, $\mathrm{PNB}_{\mathrm{K}}>1$ and $\mathrm{PNBI}_{\mathrm{K}}<0$ (negative), indicating that the soil is being depleted of $\mathrm{K}$, lowering soil fertility. The extent to which this depletion can continue without affecting yield depends on the level of soil reserves as well as the rate at which $\mathrm{K}$ becomes plant available.

Partial nutrient balance does not describe pathways of internal $\mathrm{K}$ transformation within a system (e.g., $\mathrm{K}$ dissolution or fixation in soils). It is not necessarily a direct quantitative estimate of $\mathrm{K}$ loss from the system, because $\mathrm{K}$ not removed in the harvest might remain on site in the soil. Over the long term, however, changes in soil $\mathrm{K}$ stocks are usually small relative to inputs and outputs, and therefore, low $\mathrm{PNB}_{\mathrm{K}}$ values over multiple years are reasonably reliable indirect indicators of $\mathrm{K}$ depletion.

The selection of NUE indicators should be considered in the light of the purpose of the undertaking. An indicator may be used by growers at field scale or as a statement of accountability at a regional and/or industry scale. The two reasonswhile not mutually exclusive-do require clarity of purpose and transparency of data used to derive them. None of the indicators reference soil health or soil nutrient concentrations, so they are incomplete in their description of sustainability impacts. Because marginal nutrient use declines as the nutrient is supplied, the highest values of many indicators occur at the lowest level of application which is also likely the lowest yield. More discussion on selecting appropriate nutrient performance indicators can be found in Fixen et al. (2015) and Norton et al. (2015).

\subsubsection{Uncertainties in Estimating Nutrient Balances}

Nutrient balances provide perspective on the extent of nutrient sources relative to crop demand and may be helpful in identifying opportunities to improve nutrient use efficiency. However, unlike a financial balance sheet, nutrient balances involve considerable uncertainty, particularly at regional and national scales. These uncertainties derive from regional variations in crop $\mathrm{K}$ concentration, inadequate information on nutrient removal by some crops, lack of information on the contribution of manure, inability to account for nutrient loss by runoff and erosion, poor fertilizer use data, and other factors. Because of these sources of error, at best, nutrient balance is only a partial balance (Roberts and Majumdar 2017). 
Deriving these ratios relies on reliable data on crop production (e.g., FAOSTAT), fertilizer use (e.g., IFA industry statistics), and crop product nutrient density (e.g., FAOSTAT). While of interest at a general level, the data do not provide information that can be used for system improvement and is just a reporting method. The metrics are more an assessment of the inherent $\mathrm{K}$ fertility of the system, the type of crop produced, and the farming system employed.

While production quantities are reasonably well known, the amount of grain retained on-farm for seed, animal feed, or domestic use is not often included. Also, the area of crop production could be the areas of the country, of agriculture, of arable farming, the area sown, fertilized, or harvested. The nutrient concentration of manures and organic supplements included in the budget approach is quite variable. For example, the sugar industry in Australia has an apparent high $\mathrm{PNB}_{\mathrm{K}}$ because calculations do not often include K-rich by-products from sugar mills that are recycled back onto cane fields.

A second aspect of the uncertainties is the concentration of the nutrient in the product removed as well as in nutrient inputs. For example, Norton (2012) reported that $\mathrm{K}$ concentrations in wheat grain varied by $\pm 14 \%$ of the mean value for dry grain of $4606 \mathrm{mg} \mathrm{K} \mathrm{kg}{ }^{-1}$. As a consequence, any $\mathrm{PNB}_{\mathrm{K}}$ or $\mathrm{PFP}_{\mathrm{K}}$ is likely to have a $10-15 \%$ error embedded in the data used to derive the metric.

Thirdly, there are few reliable data sets on the use of fertilizers on different crops, and the best current data at the national level was reported by Heffer (2013), although regional agricultural and resource management groups may also hold similar data from farm surveys, various agricultural agencies, or the fertilizer industry. Even so, not many sources disaggregate the data to fertilizer use by production region and crop, which is really the detail required for growers and advisors to make system-level improvements.

Finally, a single fertilizer application may carry through to a second and often different crop, such as in a maize-soybean rotation. The residual nutrient carryover and then removal by the second crop is not accounted for, similar to not taking account of $\mathrm{K}$ released from soil minerals in the balance calculations.

The critical aspects of developing these metrics are to ensure that the data are transparent, auditable, referenced, consider all nutrient sources, and are regionally relevant and appropriate to the intention as to how the metrics are to be interpreted.

\subsubsection{Interpreting Nutrient Balance Information}

The first and most significant issue to consider when interpreting a nutrient metric is the degree of limitation that the particular nutrient imposes on the system studied. If the nutrient is not limiting crop growth due to high soil reserves or other biotic or abiotic influences, then the value of $\mathrm{PNB}_{\mathrm{K}}$ and $\mathrm{PFP}_{\mathrm{K}}$ will be high, as little $\mathrm{K}$ fertilizer is applied relative to yield and nutrient removal. This can give an unrealistic impression of the potential returns on $\mathrm{K}$ investment from the $\mathrm{PFP}_{\mathrm{K}}$ value and an over-assessment of the degree of soil depletion occurring from $\mathrm{PNB}_{\mathrm{K}}$. In such cases, 
$\mathrm{PNBI}_{\mathrm{K}}$ may be a more accurate indicator of soil depletion since it is an extensive or area-based rather than intensive metric.

Where $\mathrm{K}$ is the most limiting nutrient, over the long term and within the bounds of errors associated with the data, it is desirable for $\mathrm{PNB}_{\mathrm{K}}$ to approach unity, so that input and output are balanced. When $\mathrm{PNB}_{\mathrm{K}}<0.5$, there is probably an opportunity for using evidence-based nutrient management principles to improve efficiency. At the other extreme, when $\mathrm{PNB}_{\mathrm{K}}>1.0$, it is likely that efficiency cannot be improved further without risking the depletion of soil supply. However, this should not imply that $\mathrm{PNB}_{\mathrm{K}}$ values between 0.5 and 1.0 are necessarily acceptable, because, as already noted, a $\mathrm{PNB}_{\mathrm{K}}$ value of, say 0.7 , maybe good for some systems in some places and not so good for other systems in other places.

While mean values are useful, downscaled nutrient performance indicators from dairy farms (Gourley et al. 2012) and grain farms (Norton 2017) are highly variable and generally skewed. While the distribution of these values can be informative for growers as benchmarks for nutrient performance in a participatory research setting, valid comparisons can only be made among similar systems.

Trends in efficiency metrics can be viewed in a broader background against economic development in general. An economic Kuznets curve (Kuznets 1955) identifies that as an economy develops, resource-use metrics like PNB initially indicate unsustainability (such as PNB $>>1$ ) as resources are exploited, but then resource use becomes more sustainable as inputs become economic. So nutrient PNBs are likely to reflect the stage of economic development and agricultural industrialization as well as production systems management.

\subsection{Australia}

In Australia, grazing land accounts for $87 \%$ of agricultural land use, with $16 \%$ of land under improved pastures. Around $50 \mathrm{M}$ ha is used for crop production, with less than $5 \%$ irrigated. Farmers produce around $40 \mathrm{Mt}$ of grains annually, with wheat (Triticum aestivum L.) (24 Mt) and barley (Hordeum vulgare L.) (7 Mt) as the main grains. Sugarcane (Saccharum giganteum (Walter) Pers.), cotton (Gossypium hirsutum L.), and viticulture are worth a total of around $\$ 4.2$ billion annually, while other horticultural crops add another $\$ 8$ billion. The Australian beef, sheep, and dairy industries are largely pasture-based, and the gross value of slaughtering is over $\$ 7.3$ billion, while dairy products ( $\$ 4.7$ billion) and wool ( $\$ 2.6$ billion) are also significant industries. Grain and red meat production are highly variable due to seasonal conditions, and growers are careful with the allocation of production resources (ABARES 2016).

All the $\mathrm{K}$ fertilizer used in Australia is imported, and the annual peak quantity of imported $\mathrm{KCl}$ was $480 \mathrm{kt} 2004 / 2007$, equivalent to $239 \mathrm{kt} \mathrm{K}$, assuming $\mathrm{KCl}$ averaged $60 \% \mathrm{~K}_{2} \mathrm{O}$. The annual peak of $\mathrm{K}_{2} \mathrm{SO}_{4}$ imports was $60 \mathrm{kt}$ in 2012, or $25 \mathrm{kt} \mathrm{K}$, calculated using a $50 \% \mathrm{~K}_{2} \mathrm{O}$ concentration for $\mathrm{K}_{2} \mathrm{SO}_{4}$. Long-term $\mathrm{K}$ use has been $\sim 170 \mathrm{kt}$ of $\mathrm{K}$, but during the "Millennium Drought" total $\mathrm{K}$ fertilizer use 
Fig. 11.1 Partial nutrient balance intensity $\left(\mathrm{PNBI}_{\mathrm{K}}\right.$, $\mathrm{kg} \mathrm{K} \mathrm{ha}{ }^{-1}$ ) across different natural resource

management regions across Australia for (a) 2007-2008 and (b) 2011-2012. Values reported are the means for each 2-year period. In general, the red regions indicate where nutrient removal is more than nutrient supply. (OzDSM 2020)

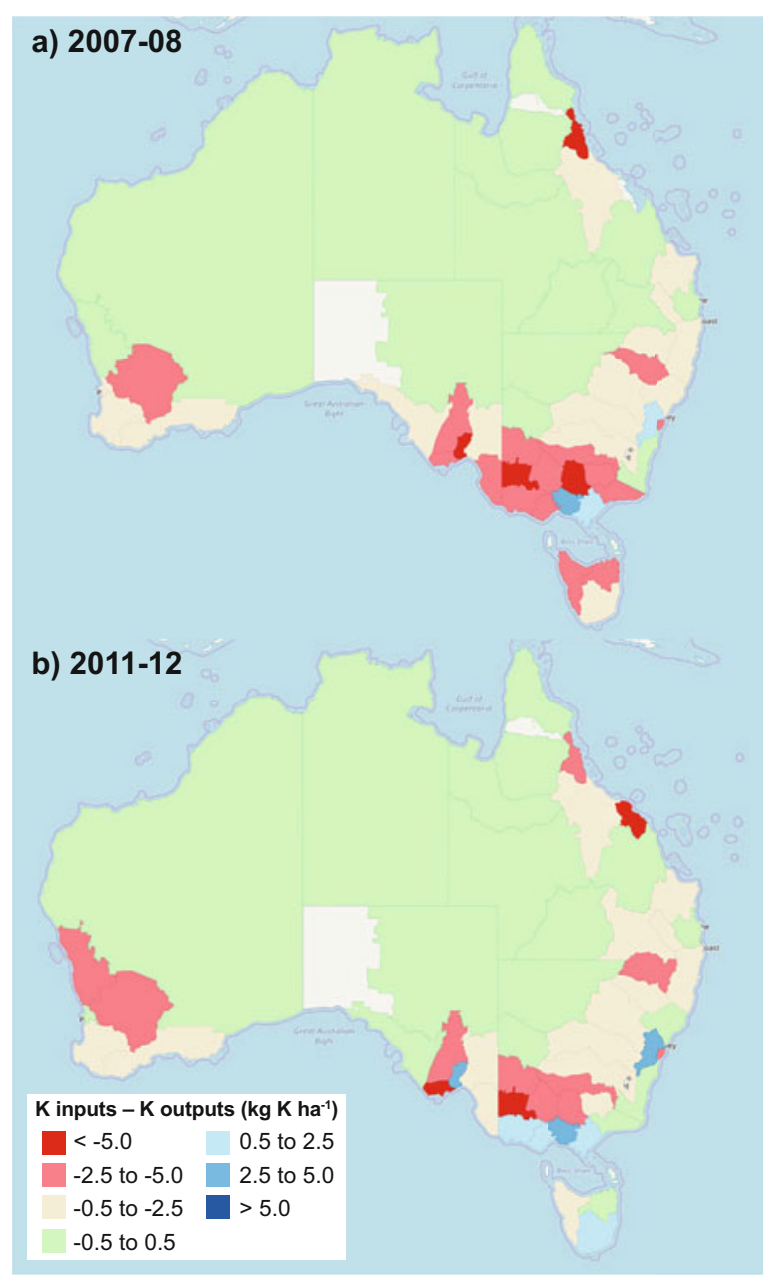

declined to a low of $134 \mathrm{kt} \mathrm{K}$ in 2009 , but has since recovered to $227 \mathrm{kt} \mathrm{K}$ according to the 2016-2017 report from Fertilizer Australia (Drew 2018). This amount makes up less than $1 \%$ of the global $\mathrm{K}$ used.

Using the agricultural production and fertilizer use data, $\mathrm{PNB}_{\mathrm{K}}$ can be calculated at national and regional scales, with regional fertilizer use data derived from farm surveys (ABS 2016). In aggregate, the national $\mathrm{PNB}_{\mathrm{K}}$ was 2.9 for the audited period, and $\mathrm{PNBI}_{\mathrm{K}}$ was $-0.6 \mathrm{~kg} \mathrm{~K} \mathrm{ha}^{-1}$, with the denominator used as the area of land used for agricultural production. These values are consistent with the National Land and Water Resources Audit (2001) which reported that K use was around one-third of the amount of $\mathrm{K}$ removed.

The patterns across different Australian resource management regions for two audit periods are shown in Fig. 11.1. The distribution of the balances largely reflects the balance of enterprises within each region, as well as the inherent $\mathrm{K}$ fertility of the 
Table 11.2 Partial $\mathrm{K}$ balance $\left(\mathrm{PNB}_{\mathrm{K}}\right)$ and the nutrient balance intensity $\left(\mathrm{PNBI}_{\mathrm{K}}\right)$ averaged for 2008 and 2010: mean rates are derived from the reported fertilizer use and the areas fertilized; the proportion of the total $\mathrm{K}$ fertilizer used by each industry was derived from the survey data

\begin{tabular}{|c|c|c|c|c|}
\hline & $\begin{array}{l}\text { Partial nutrient } \\
\text { balance }\left(\mathrm{PNB}_{\mathrm{K}}\right)\end{array}$ & $\begin{array}{l}\text { Partial nutrient } \\
\text { balance intensity } \\
\left(\mathrm{PNBI}_{\mathrm{K}}\right)\end{array}$ & $\begin{array}{l}\text { Mean } \\
\text { application } \\
\text { rate of } \mathrm{K}\end{array}$ & $\begin{array}{l}\text { Industry } \\
\text { proportion of } \\
\text { K use }\end{array}$ \\
\hline Industry & Unitless & $\mathrm{kg} \mathrm{K} \mathrm{ha}^{-1}$ & $\mathrm{~kg} \mathrm{~K} \mathrm{ha}^{-1}$ & $\%$ \\
\hline $\begin{array}{l}\text { Grain and } \\
\text { livestock }\end{array}$ & 3.1 & 3.7 & 2 & 14 \\
\hline Other grains & 5.5 & 4.1 & 1 & 19 \\
\hline Rice & 6.9 & 14.8 & 2 & 0 \\
\hline Cotton & 0.5 & -10.6 & 23 & 7 \\
\hline Sugarcane & 7.6 & 84.9 & 13 & 5 \\
\hline $\begin{array}{l}\text { Vegetables } \\
\text { (outdoors) }\end{array}$ & 1.2 & 4.8 & 21 & 6 \\
\hline $\begin{array}{l}\text { Tree fruits and } \\
\text { vines }\end{array}$ & 1.3 & 3.7 & 14 & 10 \\
\hline $\begin{array}{l}\text { Sheep farming, } \\
\text { specialized }\end{array}$ & 2.9 & 3.1 & 2 & 4 \\
\hline $\begin{array}{l}\text { Beef cattle farm- } \\
\text { ing, specialized }\end{array}$ & 1.5 & 3.1 & 6 & 16 \\
\hline $\begin{array}{l}\text { Sheep-beef cat- } \\
\text { tle farming }\end{array}$ & 2.9 & 1.7 & 2 & 4 \\
\hline $\begin{array}{l}\text { Dairy cattle } \\
\text { farming }\end{array}$ & 1.6 & 5.5 & 10 & 17 \\
\hline
\end{tabular}

ABS (2016)

soils. In essence, the areas where $\mathrm{K}$ was in the largest deficit were in the sugargrowing areas in Queensland and the lower rainfall grain-growing regions of Western Australia, South Australia, and Central Queensland. It should be noted that the data used to generate these maps did not include any recycled materials such as mill wastes from sugar processing or manures used as inputs into crop production.

Edis et al. (2012) used farm survey data that included fertilizer inputs estimated for each industry to disaggregate $\mathrm{PNB}_{\mathrm{K}}$ and $\mathrm{PNBI}_{\mathrm{K}}$ by commodity. These data are summarized in Table 11.2, which shows that all industries except cotton have more $\mathrm{K}$ removed than applied as fertilizer. Cotton is usually grown in rotation with other annual crops so the true $\mathrm{K}$ balance is confounded by fertilizer practices on those other crops. There is much less $\mathrm{K}$ applied than is removed and the largest apparent deficits are in the grains, sugar, and dairy industries. Recycled K-rich mill wastes are not included for the sugar industry, and $\mathrm{PNB}_{\mathrm{K}}$ and $\mathrm{PNBI}_{\mathrm{K}}$ for the dairy industry do not include $\mathrm{K}$ supplied to pastures that is ultimately derived from feeds purchased from outside the farm-gate. Gourley et al. (2012) reported that $\mathrm{K}$ from cattle feed averaged $25 \mathrm{~kg} \mathrm{~K} \mathrm{ha}^{-1}$ compared to a fertilizer input of $32 \mathrm{~kg} \mathrm{~K} \mathrm{ha}^{-1}$ from data collected on 44 dairy farms across Australia, so that total K input in this industry may be underestimated. 
While it may be of interest to compare industries or regions, there are important limitations in the data presented in both Fig. 11.1 and Table 11.2. The survey sample sizes are small which leads to up-scaling errors, and in these data, the up-scaled national $\mathrm{K}$ use is about $65 \%$ of the fertilizer industry-reported consumption. Underreporting of $\mathrm{K}$ use in these farm surveys is likely a consequence of imprecise survey questions that, for example, do not discriminate fertilizer product application rate from nutrient rate. Regional differences in product nutrient density, rotations used, and the extent of the use of recycled matter all make the actual values imprecise and of limited value in drawing conclusions about the efficiency of different production systems.

However, the major significant deficiency in these types of regional or industrybased data is that averages provide little or no intelligence to growers on their farmlevel balances. The data collected by Gourley et al. (2012) for the dairy industry and Norton and vanderMark (2016) for the grains industry gives error terms around the inputs, as well as the derived metrics concerning nutrient use efficiency.

\subsubsection{Southern Australian Grain Farms}

While regional performance indicators are of interest in a policy sense, the collection and collation of nutrient removal and use at farm or field levels are more important to growers, as these data inform them about how their specific management practices have built up or depleted nutrients over time. Such an understanding will help them make decisions about appropriate interventions to address any imbalances.

Norton (2017) reported nutrient performance indicators from a survey of 474 fields (34,900 ha) between 2010 and 2014 in south-eastern Australia. Nutrient balances (nitrogen $[\mathrm{N}]$, phosphorus $[\mathrm{P}], \mathrm{K}$, and sulfur [S]) for each field over the audit period were estimated from fertilizer use, stubble management (burned, removed, grazed), and crop yield. Grain and hay yields were recorded in the farm records, and regional wheat grain nutrient concentrations for wheat (Norton 2012) and canola (Brassica napus L.) (Norton 2014a) were used to estimate removal in grains. Other values were derived from the values used in the NLWA (2001). The summary presented here is for the $\mathrm{K}$ balances alone.

Even though $20 \%$ of surveyed fields received $\mathrm{K}$ fertilizer, with an average $\mathrm{K}$ application rate of $<10 \mathrm{~kg} \mathrm{~K} \mathrm{ha}^{-1}$ year $^{-1}$, where $\mathrm{K}$ fertilizer was used, the application rates were about $90 \mathrm{~kg} \mathrm{~K} \mathrm{ha}^{-1}$ on canola and $66 \mathrm{~kg} \mathrm{~K} \mathrm{ha}^{-1}$ on cereals. On the fields where $\mathrm{K}$ was applied, $\mathrm{PNB}_{\mathrm{K}}$ and $\mathrm{PFP}_{\mathrm{K}}$ were calculated with the median $\mathrm{PNB}_{\mathrm{K}}$ of 3.0, and only seven of the fields surveyed showed more $\mathrm{K}$ use than removal over the audit period. Even where $\mathrm{K}$ was used, 12 fields had $\mathrm{PNB}_{\mathrm{K}}>5$ (Fig. 11.2a). The $\mathrm{PFP}_{\mathrm{K}}$ values where $\mathrm{K}$ was used had a median of $350 \mathrm{~kg}_{\text {grain kg}}{ }^{-1} \mathrm{~K}$ (Fig. 11.2b).

The low use of $\mathrm{K}$ in eastern Australia in particular can be explained by the generally high soil test $\mathrm{K}$ values, indicating that supplementary $\mathrm{K}$ was not required. Christy et al. (2015) re-analyzed soil test data collected in the NLWA (2001) to assess the proportion of areas where a response to $\mathrm{K}$ was likely based on the soil test 

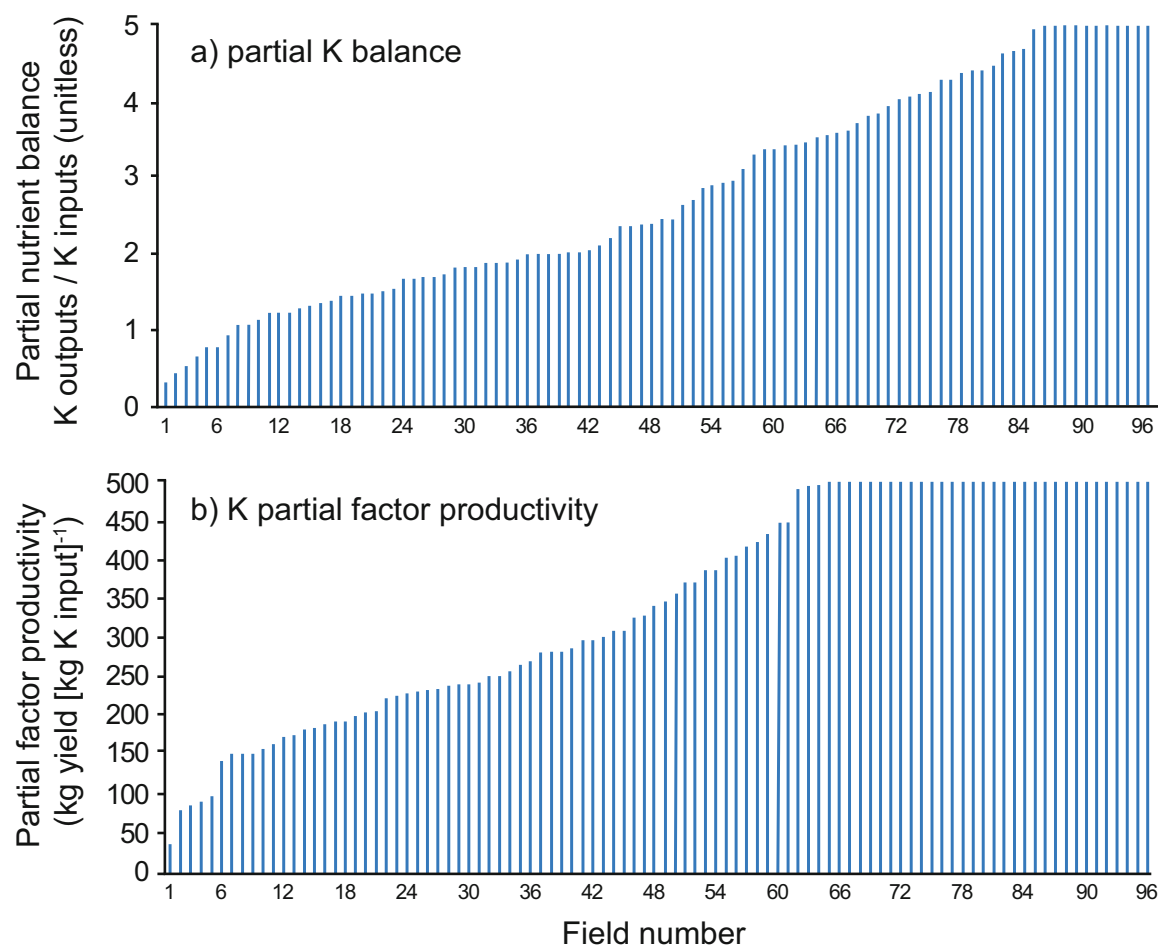

Fig. 11.2 Nutrient performance metrics for $K$ as derived from a survey of Australian farmers' fields: (a) partial nutrient balance $\left(\mathrm{PNB}_{\mathrm{K}}\right)$, and (b) partial factor productivity $\left(\mathrm{PFP}_{\mathrm{K}}\right)$. (adapted from Norton 2017)

critical values (Brennan and Bell 2013). In the south-eastern grain-producing areas, soil $\mathrm{K}$ concentrations are generally higher in the lower rainfall areas, but there are regions in the higher rainfall zones near the coast where yield responses to added $\mathrm{K}$ are likely. About half the $\mathrm{K}$ soil test values on sand and loam soil types in southwestern Victoria are low and these are coincident with the areas where $\mathrm{K}$ fertilizer was reported to be applied from the farm survey (Christy et al. 2015). In particular, low soil $\mathrm{K}$ concentrations were seen on lighter acid soils under high rainfall conditions and also in formed-in-place Vertosols in both Victoria and Queensland.

\subsubsection{Trends in Potassium Removal}

Similar to the high $\mathrm{PNB}_{\mathrm{K}}$ values reported in the NLWA (2001), Bell and Moody (2005) reported consistently negative $\mathrm{K}$ budgets for grain farms in the northern cropping region of Australia. The extent of the deficit was linked to regional crop 
productivity and the low use of $\mathrm{K}$ fertilizer. Potassium removal was highest in chickpea (Cicer arietinum L.) crops because of the higher than average grain $\mathrm{K}$ concentrations in chickpeas being consistently higher yielding than crops like sorghum (Sorghum bicolor (L.) Moench). Typically, K removals were between 8 and $20 \mathrm{~kg} \mathrm{~K} \mathrm{ha}^{-1}$ year $^{-1}$ over a five-crop sequence. They also reported low and declining soil K concentrations in many of the summer cropping regions in Queensland. Soil test $\mathrm{K}$ values showed stratification with around 1.6-3.2 times more exchangeable $\mathrm{K}$ in the topsoil than the subsoil. This depletion has largely gone undetected by soil tests which generally represent only the $0-10 \mathrm{~cm}$ topsoil. There are now research projects investigating deep placement of $\mathrm{K}$ (and P) as a means of alleviating this deficiency.

There is concern about this depletion trend more widely in regions where $\mathrm{K}$ fertilizer has not been traditionally used. Key factors indicating a future $\mathrm{K}$ response are cropping on soils that have low to moderate exchangeable and non-exchangeable $\mathrm{K}$ reserves, and where $\mathrm{K}$ removal in harvested grain and hay is high. Indeed, the consistently low grain $\mathrm{K}$ concentrations in some areas coupled with some very low $\mathrm{K}$ usage suggested that the soil K status may be approaching low levels-whether due to stratification, presence of high sodium $(\mathrm{Na})$, or the lack of substantial non-exchangeable $\mathrm{K}$ reserves.

Potassium fertilizer use in Australia is relatively modest on a world scale, and there is approximately 3 times more $\mathrm{K}$ removed in agricultural products than is supplied. While $\mathrm{K}$ removal is highest on sugarcane farms, there is a modest deficit for most farms due to low productivity. Regional differences in $\mathrm{K}$ use and $\mathrm{PNB}_{\mathrm{K}}$ reflect the intensity of production and the inherent $\mathrm{K}$ fertility of the regions, although there are inconsistencies in the data available to estimate $\mathrm{K}$ balances and nutrient performance indicators. Western Australia uses most $\mathrm{K}$ fertilizer for grain production. Victoria uses $\mathrm{K}$ mainly on intensive pastures (especially dairy), while in Queensland K is mainly focused on the sugar industry. The data presented here indicate that grain-producing fields in the higher rainfall regions of southern Australia are in significant $\mathrm{K}$ deficit, despite the low inherent $\mathrm{K}$ fertility. Private, state, and federal agencies are addressing and communicating evidence-based nutrient management strategies to growers to overcome these deficits and improve productivity (Norton 2014b, Norton and vanderMark 2016).

\subsection{Southeast Asia}

The $\mathrm{K}$ balance assessment for Southeast Asia includes four crops most important both economically and for $\mathrm{K}$ use: rice (Oryza sativa L., maize (Zea mays L.), sugarcane, and oil palm (Elaeis guineensis Jacq.) in five countries in the region: Indonesia, Malaysia, Philippines, Thailand, and Vietnam. The choice of crops, countries, and crop year included in the $\mathrm{K}$ balance estimation were based on the availability of data on fertilizer $\mathrm{K}$ application by crop and country. The latest 
available dataset with the highest number of countries and crops in the region was reported by Heffer (2013) for the crop year 2010-2011.

\subsubsection{Data Sources and Limitations}

In 2010-2011, the five countries produced a total of $148.5 \mathrm{Mt}$ of rice grain, 23.0 Mt of maize grain, 132.3 Mt of cane sugar, and 218.8 Mt of palm oil (as fresh fruit bunch) (Table 11.3). The total area harvested for these four crops was 57.3 Mha, accounting for $61 \%$ of the total crop area (94.9 Mha of arable land and permanent cropland) in the five countries (Table 11.4). For each crop, the percentage of the total crop area was: $38 \%$ for rice, $8 \%$ for maize, $3 \%$ for sugarcane, and $12 \%$ for oil palm.

For the estimation of crop K removal, production data for 2010 and 2011 (Table 11.5) was combined with published values of $\mathrm{K}$ content in harvested crop biomass. These values were $2.83 \mathrm{~g} \mathrm{~K} \mathrm{~kg}^{-1}$ for rice grain (Buresh et al. 2010); $2.38 \mathrm{~g}$ $\mathrm{K} \mathrm{kg}^{-1}$ maize grain (Setiyono et al. 2010); $1.1 \mathrm{~g} \mathrm{~K} \mathrm{~kg}^{-1}$ cane sugar (Dierolf et al. 2001); $3.87 \mathrm{~g} \mathrm{~K} \mathrm{~kg}^{-1}$ oil palm fresh fruit bunch for Indonesia (Donough et al. 2014);

Table 11.3 Production levels of four crops in five Southeast Asian countries, 2010-2011 season

\begin{tabular}{l|l|l|l|l}
\hline \multirow{2}{*}{ Country } & $\begin{array}{l}\text { Rice } \\
\text { production }\end{array}$ & $\begin{array}{l}\text { Maize } \\
\text { production }\end{array}$ & $\begin{array}{l}\text { Sugarcane } \\
\text { production }\end{array}$ & $\begin{array}{l}\text { Oil palm } \\
\text { production }\end{array}$ \\
\cline { 2 - 5 } kt grain & kt grain & kt sugar & kt fresh fruit bunch \\
\hline Indonesia & 56,349 & 6800 & 15,391 & 118,000 \\
\hline Malaysia & 2526 & 95 & 174 & 91,055 \\
\hline Philippines & 16,729 & 7271 & 21,913 & 565 \\
\hline Thailand & 30,700 & 4200 & 84,026 & 9160 \\
\hline Vietnam & 42,194 & 4607 & 10,783 & - \\
\hline Total & 148,498 & 22,973 & 132,287 & 218,780 \\
\hline
\end{tabular}

Data source: USDA FAS (2017); oil palm production is reported here as fresh fruit bunch instead of palm oil as reported by USDA. Oil palm fresh fruit bunch is calculated by assuming an oil extraction of $20 \%$ (Corley and Tinker 2016)

Table 11.4 Harvested area of four crops in five Southeast Asian countries, 2010-2011 season

\begin{tabular}{l|l|l|l|l}
\hline \multirow{2}{*}{ Country } & $\begin{array}{l}\text { Rice area } \\
\text { harvested }\end{array}$ & $\begin{array}{l}\text { Maize area } \\
\text { harvested }\end{array}$ & $\begin{array}{l}\text { Sugarcane area } \\
\text { harvested }\end{array}$ & $\begin{array}{l}\text { Oil palm area } \\
\text { harvested }\end{array}$ \\
\cline { 2 - 5 } Indonesia & 1000 ha & 1000 ha & 1000 ha & 1000 ha \\
\hline Malaysia & 672 & 2850 & 435 & 6801 \\
\hline Philippines & 4528 & 27 & 4 & 4202 \\
\hline Thailand & 10,667 & 2633 & 440 & 45 \\
\hline Vietnam & 7607 & 1000 & 1259 & 600 \\
\hline Total & 35,549 & 7637 & 282 & - \\
\hline
\end{tabular}

Data sources: USDA FAS (2017) for rice, maize, and oil palm; FAOSTAT (2017) for sugarcane (USDA FAS (2017) does not provide data for sugarcane) 
Table 11.5 Inputs of K fertilizer, $\mathrm{K}$ removal with crop harvest, and partial nutrient balance intensity $\left(\mathrm{PNBI}_{\mathrm{K}}\right)$ of four crops in five countries in Southeast Asia, 2010-2011

\begin{tabular}{l|l|l|l|l}
\hline & Rice & Maize & Sugarcane & Oil palm \\
\cline { 2 - 5 } & kt $\mathrm{K}_{2} \mathrm{O}$ & kt $\mathrm{K}_{2} \mathrm{O}$ & $\mathrm{kt} \mathrm{K}_{2} \mathrm{O}$ & kt $\mathrm{K}_{2} \mathrm{O}$ \\
\hline K applied $^{\mathrm{a}}$ & \multicolumn{5}{|l}{} \\
\hline Indonesia $^{-}$ & 138 & 100 & 63 & 775 \\
\hline Malaysia & 55 & 1 & 1 & 989 \\
\hline Philippines & 24 & 6 & 13 & 2 \\
\hline Thailand & 22 & 19 & 81 & 47 \\
\hline Vietnam & 240 & 26 & 32 & - \\
\hline Total & 479 & 152 & 190 & 1813 \\
\hline
\end{tabular}

K removed with harvested crop ${ }^{\mathrm{b}}$

\begin{tabular}{l|l|l|l|l}
\hline Indonesia & 192 & 20 & 20 & 550 \\
\hline Malaysia & 9 & 0.3 & 0.2 & 385 \\
\hline Philippines & 57 & 21 & 29 & 3 \\
\hline Thailand & 105 & 12 & 111 & 43 \\
\hline Vietnam & 144 & 13 & 14 & - \\
\hline Total & 507 & 66 & 175 & 981 \\
\hline
\end{tabular}

Partial nutrient balance intensity $\left(\mathrm{PNBI}_{\mathrm{K}}\right)$

\begin{tabular}{l|l|l|l|l}
\hline Indonesia & -54 & 80 & 43 & 225 \\
\hline Malaysia & 46 & 0.7 & 0.8 & 604 \\
\hline Philippines & -33 & -15 & -16 & -1 \\
\hline Thailand & -83 & 7 & -30 & 4 \\
\hline Vietnam & 96 & 13 & 18 & - \\
\hline Total & -28 & 86 & 15 & 832 \\
\hline
\end{tabular}

${ }^{a}$ Values from Heffer (2013)

${ }^{\mathrm{b}}$ Estimated using production data for 2010-2011 (USDA FAS 2017) and $K$ concentration in the harvested crop for rice grain (Buresh et al. 2010), maize grain (Setiyono et al. 2010), sugarcane (Dierolf et al. 2001), and oil palm (Tarmizi and Mohd Tayeb 2006, Donough et al. 2014)

and $3.51 \mathrm{~g} \mathrm{~K} \mathrm{~kg}^{-1}$ oil palm fresh fruit bunch for Malaysia (Tarmizi and Mohd Tayeb 2006). We assumed that the $\mathrm{K}$ content of oil palm fresh fruit bunch in the Philippines and Thailand was similar to that of Indonesia. Since oil palm production data were reported by USDA FAS (2017) as palm oil, the equivalent production of fresh fruit bunches was calculated by assuming an oil yield of $20 \%$ of fresh fruit bunch biomass (Corley and Tinker 2016).

\subsubsection{Trends in Potassium Balance}

Rice is the most important cereal crop in Southeast Asia, covering 38\% of the total crop area (Table 11.4). In rice, crop removal exceeded $\mathrm{K}$ application with a deficit of -33 to $-83 \mathrm{kt} \mathrm{K}_{2} \mathrm{O}$ in Indonesia, Philippines, and Thailand; whereas $\mathrm{K}$ application exceeded crop removal with a $\mathrm{K}$ surplus of $46 \mathrm{kt}$ and $96 \mathrm{kt} \mathrm{K}_{2} \mathrm{O}$ in Malaysia and 
Vietnam, respectively (see $\mathrm{PNBI}_{\mathrm{K}}$ values in Table 11.5). Across the five countries, there was a $\mathrm{K}$ deficit of $-28 \mathrm{kt} \mathrm{K}_{2} \mathrm{O}$ in rice-growing areas. Since the calculated $\mathrm{PNBI}_{\mathrm{K}}$ values only accounted for grain removal, greater $\mathrm{K}$ deficits are expected in areas where rice straw is also removed from the field (for off-farm use). Previous studies reported negative $\mathrm{K}$ balances in rice in irrigated long-term experiments in Indonesia, Philippines, and Vietnam (Dobermann et al. 1996) and in rainfed lowland rice in Indonesia (Wihardjaka et al. 1999).

Maize is the second most important cereal crop in Southeast Asia, with an area harvested of 7.64 million ha in the five countries (Table 11.4). Out of the five countries, only the Philippines showed a $\mathrm{K}$ deficit $\left(-15 \mathrm{kt} \mathrm{K}_{2} \mathrm{O}\right)$, while the $\mathrm{K}$ balance in the other four countries ranged from $0.7 \mathrm{kt} \mathrm{K}_{2} \mathrm{O}$ (Malaysia) to $80 \mathrm{kt} \mathrm{K}_{2} \mathrm{O}$ (Indonesia) (Table 11.5). Similar to rice, $\mathrm{PNBI}_{\mathrm{K}}$ calculations for maize only accounted for grain removal; hence $\mathrm{PNBI}_{\mathrm{K}}$ will be further reduced if $\mathrm{K}$ removed with maize stover is included. Pasuquin et al. (2014) reported cases of negative K balance in maize in Indonesia, Philippines, and Vietnam when most of the aboveground residues were removed from the field. In Southeast Asia, farmers manage their maize residues in varied ways. In the Philippines, for example, while many farmers retain the residues in their field, some still practice full removal or burning of residues to facilitate land cultivation, especially with the use of non-mechanized tillage implements.

Oil palm occupies the second largest area harvested, with Indonesia and Malaysia being the two largest producers of oil palm in the region (Table 11.4). While oil palm is only grown in four of the five countries, it is the biggest user of applied $\mathrm{K}$ fertilizer (69\%) among the four crops (Table 11.5). Potassium applications exceeded crop removal (positive $\mathrm{PNBI}_{\mathrm{K}}$ values) in Indonesia, Malaysia, and Thailand; while crop removal exceeded applications (negative $\mathrm{PNBI}_{\mathrm{K}}$ value) in the Philippines (Table 11.6).

Sugarcane covers the least area among the four crops (Table 11.4), but it is one of the important economic crops in the region and a heavy user of fertilizer $\mathrm{K}$. Table 11.5 shows that annual application of $\mathrm{K}$ exceeded crop removal by $0.8-43 \mathrm{kt} \mathrm{K}_{2} \mathrm{O}$ in Indonesia, Malaysia, and Vietnam. On the other hand, $\mathrm{K}$ deficit is indicated in the Philippines $\left(-16 \mathrm{kt} \mathrm{K}_{2} \mathrm{O}\right)$ and Thailand sugarcane production ($30 \mathrm{kt} \mathrm{K}_{2} \mathrm{O}$ ). A previous study reported negative $\mathrm{K}$ balances in Thailand for yields of $30 \mathrm{t} \mathrm{ha}^{-1}$ (of dry cane) and above at a $\mathrm{K}$ fertilizer application rate of $94 \mathrm{~kg} \mathrm{~K}_{2} \mathrm{O} \mathrm{ha}{ }^{-1}$ (Trelo-ges et al. 2004).

In the five countries in Southeast Asia included in this $\mathrm{K}$ budget, the amount of $\mathrm{K}$ fertilizer needed to replace crop removal follows the order: oil palm $>$ rice $>$ sugarcane $>$ maize (Table 11.6). To be able to replace crop removal of the four crops in five countries, a total amount of 3.46-5.76 Mt $\mathrm{K}_{2} \mathrm{O}$ will be needed at fertilizer use efficiencies of $50 \%$ and $30 \%$, respectively. With the current crop area dedicated to these crops in this region, the crops with the largest requirement for $\mathrm{K}$ fertilizer are: oil palm in Indonesia and Malaysia, rice in the Philippines and Vietnam, and sugarcane and rice in Thailand. Based on 2010-2011 fertilizer application and the estimated fertilizer requirement to replace crop removal, opportunities for improving $\mathrm{K}$ application are evident in most of the countries and crops. 
Table 11.6 Estimated fertilizer $\mathrm{K}$ requirement to replace crop removal and fertilizer $\mathrm{K}$ deficit of the current application practice at 30\% (A) and 50\% (B) fertilizer use efficiency scenarios in four crops in five Southeast Asian countries (expressed at $\mathrm{K}_{2} \mathrm{O}$ )

\begin{tabular}{|c|c|c|c|c|c|c|c|c|}
\hline \multirow[b]{3}{*}{ Country } & \multirow{2}{*}{\multicolumn{2}{|c|}{$\begin{array}{l}\text { Rice } \\
\text { kt } \mathrm{K}_{2} \mathrm{C}\end{array}$}} & \multicolumn{2}{|c|}{ Maize } & \multicolumn{2}{|c|}{ Sugarcane } & \multicolumn{2}{|c|}{ Oil palm } \\
\hline & & & & & & & & \\
\hline & $\mathrm{A}$ & B & $\mathrm{A}$ & $\mathrm{B}$ & A & B & A & B \\
\hline
\end{tabular}

Fertilizer K requirement to replace crop removal $^{\mathrm{a}}$

\begin{tabular}{l|l|l|l|l|l|l|l|l}
\hline Indonesia & 641 & 385 & 65 & 39 & 68 & 41 & 1834 & 1101 \\
\hline Malaysia & 29 & 17 & 1 & 0.5 & 1 & 0.5 & 1284 & 770 \\
\hline Philippines & 190 & 114 & 70 & 42 & 97 & 58 & 9 & 5 \\
\hline Thailand & 349 & 210 & 40 & 24 & 371 & 223 & 142 & 85 \\
\hline Vietnam & 480 & 288 & 44 & 26 & 48 & 29 & - & - \\
\hline Total & 1689 & 1014 & 220 & 132 & 584 & 351 & 3269 & 1961 \\
\hline
\end{tabular}

Fertilizer K deficit of the current application practice ${ }^{\mathrm{b}}$

\begin{tabular}{l|l|l|l|l|l|l|l|l}
\hline Indonesia & -503 & -247 & 35 & 61 & -5 & 22 & -1059 & -326 \\
\hline Malaysia & 26 & 38 & 0.1 & 0.5 & 0 & 1 & -295 & 219 \\
\hline Philippines & -166 & -90 & -64 & -36 & -84 & -45 & -7 & -3 \\
\hline Thailand & -327 & -188 & -21 & -5 & -290 & -142 & -95 & -38 \\
\hline Vietnam & -240 & -48 & -18 & -0.4 & -16 & 3 & - & - \\
\hline Total & -1210 & -535 & -68 & 20 & -394 & -161 & -1456 & -148 \\
\hline
\end{tabular}

${ }^{a}$ Using 2010-2011 crop removal data at fertilizer use efficiencies of 30\% (A) and 50\% (B) during the year of application

${ }^{\mathrm{b}}$ Difference between 2010 and 2011 fertilizer $\mathrm{K}$ application and estimated fertilizer K requirement to replace crop removal at fertilizer use efficiencies of $30 \%$ (A) and $50 \%$ (B). A negative value denotes a $\mathrm{K}$ application deficit

Fertilizer K deficits of current application practices (Table 11.6) are indicated in: rice for all countries except Malaysia; maize in the Philippines, Thailand, and Vietnam; sugarcane for all countries except Malaysia; and oil palm for all four countries. In the $30 \%$ fertilizer use efficiency scenario, there is a predicted annual total $\mathrm{K}$ deficit in the five countries of $1.2 \mathrm{Mt} \mathrm{K}_{2} \mathrm{O}$ in rice; $0.068 \mathrm{Mt} \mathrm{K}_{2} \mathrm{O}$ in maize; $0.39 \mathrm{Mt} \mathrm{K}_{2} \mathrm{O}$ in sugarcane; and $1.46 \mathrm{Mt} \mathrm{K}_{2} \mathrm{O}$ in oil palm. Current production levels also indicate opportunities for increasing production with intensification through improved crop and nutrient management, which may require a further increase in $\mathrm{K}$ fertilizer application.

\subsection{China}

China is the largest national consumer of fertilizer nutrients, accounting for nearly $30 \%$ of global fertilizer use. From 1978 to 2015 , total $\left(\mathrm{N}+\mathrm{P}_{2} \mathrm{O}_{5}+\mathrm{K}_{2} \mathrm{O}\right)$ fertilizer consumption increased from 8.8 to $60.2 \mathrm{Mt}$, with an average annual increase rate of 5.3\%. The $\mathrm{N}, \mathrm{P}_{2} \mathrm{O}_{5}$, and $\mathrm{K}_{2} \mathrm{O}$ consumption in 2015 was 30,19 , and $11 \mathrm{Mt}$, respectively. 


\subsubsection{Potassium Use and Crop Production}

Potassium deficiency in crops was initially reported in Southern China in the 1970s (Lin 1989). Potassium did not receive as much attention as $\mathrm{N}$ and $\mathrm{P}$ in the next decade but now has become a widespread limiting factor in agricultural production, especially in some parts of northeast and north-central China (Liu et al. 2000). Recent research has demonstrated that $\mathrm{K}$ deficiencies in intensified agricultural production areas in China continue to be a challenge (He et al. 2009); however, $\mathrm{K}$ fertilizer input has increased dramatically over time, rising from $0.38 \mathrm{Mt} \mathrm{K}_{2} \mathrm{O}$ in 1980 to $10.6 \mathrm{Mt} \mathrm{K}_{2} \mathrm{O}$ in 2015 , with an average annual increment of $0.29 \mathrm{Mt}$ $\mathrm{K}_{2} \mathrm{O}$. The total grain production increased from 310 to $657 \mathrm{Mt}$ during the same period, with an average annual increase rate of $2.1 \%$. Fruit and vegetable production increased annually by $6.4 \%$ and $9.8 \%$, respectively, in the past 20 years. The unprecedented growth in China's fertilizer consumption and crop production in the last decades prompted researchers to look at nutrient input-output balances. Understanding the surplus/deficit and balance of cropland nutrients provides guidance to the production, distribution, and application of fertilizer.

\subsubsection{Potassium Balance Studies}

Previous research assessed farmland nutrient balances in China, including the $\mathrm{K}$ balance at various scales (Wang et al. 2014; Chuan et al. 2014). These assessments emphasized that the nutrient balance estimations at the national scale would help develop national fertilizer policies, including decisions on investments for fertilizer factories and the exploitation of local resources and minerals to supply nutrients. Potassium balances for the 30 provinces in China from 1961 to 1997 illustrated annual $\mathrm{K}$ depletion that increased from 2.9 Mt K (3.5 Mt $\mathrm{K}_{2} \mathrm{O}$ ) in 1961 to $8.3 \mathrm{Mt} \mathrm{K}$ (10.0 Mt $\mathrm{K}_{2} \mathrm{O}$ ) in 1997 (Sheldrick et al. 2003). Negative $\mathrm{PNBI}_{\mathrm{K}}$ (from -17 to $245 \mathrm{~kg} \mathrm{~K} \mathrm{ha}^{-1}$ year $^{-1}$ ) were also reported from long-term fertilizer experiments in rice-based systems, irrespective of mineral $\mathrm{K}$ application and site (Zhang et al., 2010). Negative $\mathrm{PNBI}_{K}$ persisted on wheat-maize rotations even at $\mathrm{K}$ application rates as high as $112-300 \mathrm{~kg} \mathrm{~K}_{2} \mathrm{O}$ ha $^{-1}$ (Tan et al. 2012). A winter wheat study in the North China plain between 2005 and 2007 showed negative K balance in all the treatments under different production practices, especially at high-yield levels (Niu et al. 2013). About $79 \%$ of the assessed on-farm trials $(n=120)$ in potato (Solanum tuberosum L.) in north-western China had an average negative balance of $-102 \mathrm{~kg} \mathrm{~K}$ $\mathrm{ha}^{-1}$ ( $\mathrm{Li}$ et al. 2015). This overwhelming negative balance of $\mathrm{K}$ in soils of China started improving (becoming less negative) with the increase in fertilizer K application, along with the in-field retention of crop residues (Wang et al. 2014; Shen et al. 2005). Several studies also show significant soil K surpluses in vegetable production fields in China (Huang et al. 2007; Wang et al. 2008). 


\subsubsection{Potassium Balances in Grain and Cash Crops}

These studies provide critical information on $\mathrm{K}$ balances in China but mainly focus on specific experimental sites or short-term observations. Nutrient balances can vary considerably from year to year, and short-term studies providing limited information can be misleading.

Two follow-up studies in the past few years provide a more comprehensive overview on how soil test $\mathrm{K}$ levels and crop $\mathrm{K}$ responses changed over time and space, and the status of K balances across China. He et al. (2015) used large on-farm experimental datasets to assess spatial and temporal variation in soil test $\mathrm{K}$ and crop responses to K between 1990 and 2012. The authors utilized datasets for plantavailable $\mathrm{K}$ from on-farm experiments, where soil samples from a depth of 0-20 cm were collected and analyzed before sowing. The corresponding crop yield differences were measured between treatments fertilized with $\mathrm{N}+\mathrm{P}+\mathrm{K}$ or with only $\mathrm{N}+\mathrm{P}$. The data were spatially desegregated and grouped based on geographical locations, such as northeast (NE), northcentral (NC), northwest (NW), southeast (SE), and southwest (SW) regions of China. In addition, each region was further divided into two sub-groups based on soil utilization pattern, grain crop, and cash crop systems. The grain crop category included wheat, maize, rice, potato, and soybean (Glycine $\max ($ L.) Merr.), while the cash crop group included vegetables, fruits, rapeseed (Brassica spp.), sunflower (Helianthus annuus L.), cotton, and sugar crops. Results indicated that soil-extractable $\mathrm{K}$ concentrations (exchangeable $\mathrm{K}$ ) increased with time between 1990 and 2012. For grain crops, exchangeable K concentrations increased only slightly; however, for cash crops, the $\mathrm{K}$ concentrations increased dramatically over the period. The trends of increased soil $\mathrm{K}$ in cash crops were consistent with increased relative yield for cash crops and the high fertilizer $\mathrm{K}$ application rates. The authors suggested that higher soil $\mathrm{K}$ concentrations under cash crops increased the average soil $\mathrm{K}$ estimations in China, leading to assumptions of surplus $\mathrm{K}$ in all soils. Even though extractable $\mathrm{K}$ in soils under grain crops increased in the Northcentral, Southeast, and Southwest China in the 2000s as compared with that in the 1990 s, the average soil $\mathrm{K}$ values were less than the critical concentration of $80 \mathrm{mg} \mathrm{L}^{-1}$, except in the NW region. The results indicated that the exchangeable $\mathrm{K}$ continued to show a declining trend with large crop removal associated with higher yields.

The $\mathrm{PNB}_{\mathrm{K}}$ was greater than 1.0 for both cash and grain crop categories, suggesting that $\mathrm{K}$ removal by crop uptake exceeded $\mathrm{K}$ inputs from fertilizer (Fig. 11.3). The $\mathrm{PNB}_{\mathrm{K}}$ was higher for cash crops (mean: 2.1; range: 1.1-4.2) than for grain crops (mean: 1.3; range: 1.0-1.5), indicating higher $\mathrm{K}$ depletion in cash crops. 
Fig. 11.3 (a) Fertilizer application rate (as $\left.\mathrm{K}_{2} \mathrm{O}\right)$, (b) $\mathrm{K}$ uptake, and (c) $\mathrm{PNB}_{\mathrm{K}}$ across northeast (NE), north-central (NC), northwest (NW), southeast (SE), and southwest (SW) China for grain and cash crops. (He et al. 2015)

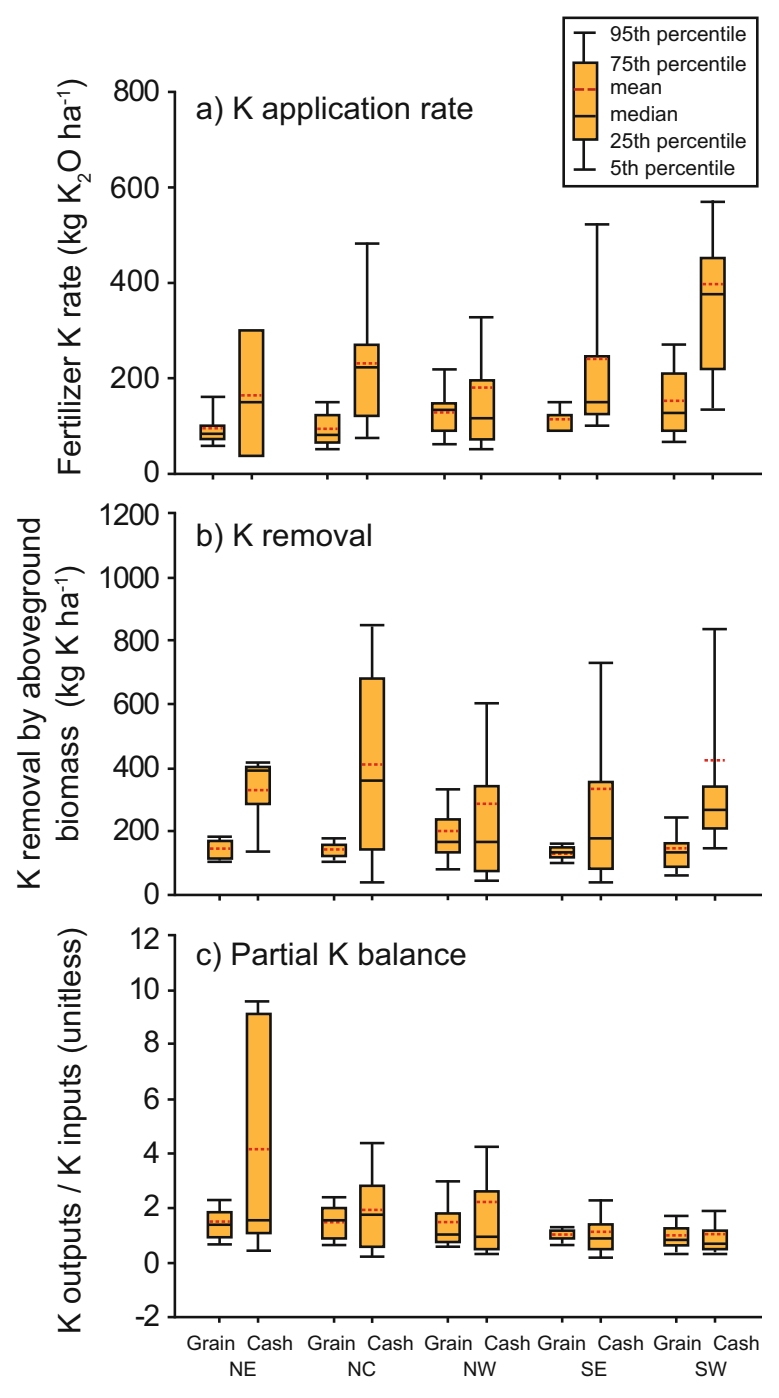

Agricultural regions and cropping systems

\subsubsection{Spatial and Temporal Changes in Potassium Balance}

A comprehensive assessment of soil K balances between 1980 and 2010 was undertaken by Liu et al. (2017b) using 31 provincial datasets from the China Agriculture Statistical Report for 1981 and 2011. The K consumption from fertilizers, human and livestock manure, straw return to field, cake manure, deposition, irrigation, seeds, crop removal, and $\mathrm{K}$ loss from soils were calculated with provincial data and parameters from refereed literature. The arable crop output was the 
principal nutrient output pathway in the agricultural systems, which was calculated through economic yield and $\mathrm{K}$ requirement per unit of economic yield of various crops. The arable crop outputs were categorized into five groups: cereal crops, fruit and vegetables (fruit, vegetable, and melons), oil crops (oil crops and beans), industrial crops (sugar beet (Beta vulgaris L.), sugarcane, fiber crops, cotton and tobacco (Nicotiana tabacum L.)) and root crops (sweet potato (Ipomoea batatas (L.) Lam.) and potato). The $\mathrm{PNBI}_{\mathrm{K}}\left(\mathrm{kg} \mathrm{K}_{2} \mathrm{O}\right.$ or $\mathrm{kg} \mathrm{K}_{2} \mathrm{O} \mathrm{ha}{ }^{-1}$ ) was estimated by calculating the total $\mathrm{K}$ added to farmland from various sources during the year (inputs) and subtracting the total amount of $\mathrm{K}$ removed from farmland by crop removal and $\mathrm{K}$ loss from leaching and runoff (outputs).

The farmland $\mathrm{PNBI}_{\mathrm{K}}$ was significantly different between 1980 and 2010 at the provincial scale. The $\mathrm{PNBI}_{\mathrm{K}}$ in China changed from an average deficit of $-13.6 \mathrm{~kg}$ $\mathrm{K}_{2} \mathrm{O} \mathrm{ha}^{-1}$ in 1980 to a surplus of $22.9 \mathrm{~kg} \mathrm{~K}_{2} \mathrm{O} \mathrm{ha}^{-1}$ in 2010 (Fig. 11.4). In 1980, almost $68 \%$ of the farmland area across 19 provinces showed $\mathrm{K}$ deficits (very low and low classes); however, $30 \%$ of farmland area in 10 provinces had $\mathrm{PNBI}_{\mathrm{K}}$ in the moderate class (1-50 $\mathrm{kg} \mathrm{K}_{2} \mathrm{O} \mathrm{ha}{ }^{-1}$ ) (Fig. 11.4a). In 2010, 40 and $44 \%$ of the farmland was in the low and moderate $\mathrm{PNBI}_{\mathrm{K}}$ classes in 9 and 13 provinces, respectively. Meanwhile, $11 \%$ of farmland was in the high $\mathrm{PNBI}_{\mathrm{K}}$ class in 5 provinces. Only $6 \%$ of farmland area showed a $\mathrm{PNBI}_{\mathrm{K}}$ in the very high class in four provinces (Fig. 11.4).

Liu et al. (2017a) followed up with a more comprehensive $\mathrm{K}$ balance across four decades: 1980-1989, 1990-1999, 2000-2009, and 2010-2015. The data were desegregated into six agricultural regions, based on geographical locations and China's administrative divisions: northeast (NE); north-central (NC); northwest (NW); the middle and lower reaches of the Yangtze River (MLYR); southeast (SE); and southwest (SW).

Mineral fertilizer, organic manure, and other $\mathrm{K}$ input resources (atmospheric deposition, irrigation, and seeds) accounted for $33 \%\left(4.91 \mathrm{Mt} \mathrm{K}_{2} \mathrm{O}\right), 59 \%(8.85 \mathrm{Mt}$ $\mathrm{K}_{2} \mathrm{O}$ ), and $8 \%\left(1.19 \mathrm{Mt} \mathrm{K}_{2} \mathrm{O}\right)$ of the total $\mathrm{K}$ input from 1980 to 2015 , respectively. The $\mathrm{K}$ input through fertilizers increased from $0.38 \mathrm{Mt} \mathrm{K}_{2} \mathrm{O}$ in 1980 to $10.58 \mathrm{Mt}$ $\mathrm{K}_{2} \mathrm{O}$ in 2015. At the regional level, $\mathrm{K}$ inputs increased in all regions over time. Increases in $\mathrm{K}$ inputs were greatest for the SE and least for both the NW and NE (Fig. 11.5a). By 2015, K input in the SE was the highest, followed by the SW, MLYR, NC, NW, and NE.

The average K output from 1980 to 2015 was $14.78 \mathrm{Mt} \mathrm{K}_{2} \mathrm{O}\left(146 \mathrm{~kg} \mathrm{~K}_{2} \mathrm{O} \mathrm{ha}^{-1}\right.$ year $\left.^{-1}\right)$. Crop removal accounted for $99 \%\left(14.63 \mathrm{Mt} \mathrm{K}_{2} \mathrm{O}\right)$ of the total output from 1980 to 2015 . Cereals removed 70, 65, 55, and $56 \%$ of the total $\mathrm{K}$ output in the 1980s, 1990s, 2000s, and 2010s, respectively. The K output of fruit and vegetables and oil crops increased over the years with average annual increments of 0.13 and $0.05 \mathrm{Mt}$ of $\mathrm{K}_{2} \mathrm{O}$, respectively. Potassium outputs increased over time in all regions (Fig. 11.5). The K outputs in MLYR and SE were significantly larger than those in other regions. In the NE, K outputs increased from 1982 to 1989 then stabilized, with some variation, from 1990 on.

Potassium nutrient balance intensity increased from its lowest value in 1984 $\left(-3.23 \mathrm{Mt} \mathrm{K}_{2} \mathrm{O}\right)$ to a relatively stable value of around $2.1 \mathrm{Mt} \mathrm{K}_{2} \mathrm{O}$ in 2015. At the 

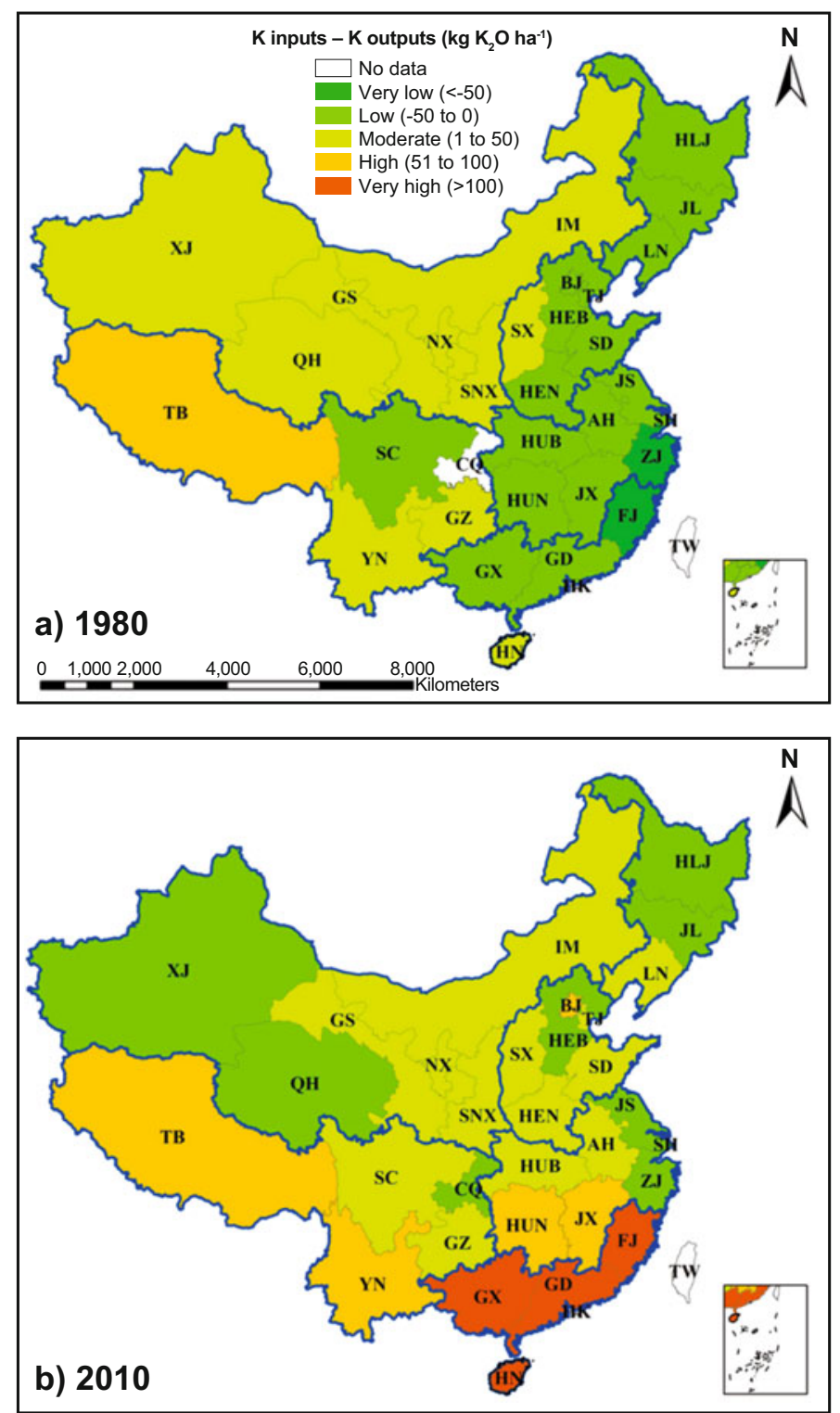

Fig. 11.4 Spatial distributions of $\mathrm{PNBI}_{\mathrm{K}}$ in China's agricultural land in (a) 1980 and (b) 2010. Adapted from Liu et al. (2017b)

national scale, the average $\mathrm{PNBI}_{\mathrm{K}}$ from 1980 to 2015 was $0.81 \mathrm{~kg} \mathrm{~K}_{2} \mathrm{O}_{\text {ha }}{ }^{-1}$ year ${ }^{-1}$. On average, the $\mathrm{PNBI}_{\mathrm{K}}$ changed from its 1980 level by $-24.2 \mathrm{~kg} \mathrm{~K}_{2} \mathrm{O} \mathrm{ha}{ }^{-1}$ in the $1980 \mathrm{~s},-5.9 \mathrm{~kg} \mathrm{~K}_{2} \mathrm{O} \mathrm{ha}^{-1}$ in the $1990 \mathrm{~s}, 21.3 \mathrm{~kg} \mathrm{~K}_{2} \mathrm{O}^{-1}$ in the $2000 \mathrm{~s}$, and $19.5 \mathrm{~kg}$ $\mathrm{K}_{2} \mathrm{O} \mathrm{ha}^{-1}$ in the 2010s. The average $\mathrm{PNBI}_{\mathrm{K}}$ in the $\mathrm{SE}$ region increased steadily 
Fig. 11.5 Temporal and regional variation of: (a) $\mathrm{K}$ inputs, (b) K outputs, and (c) $\mathrm{PNBI}_{\mathrm{K}}$ in six regions of China from 1980 to 2015. (adapted from Liu et al. 2017a)
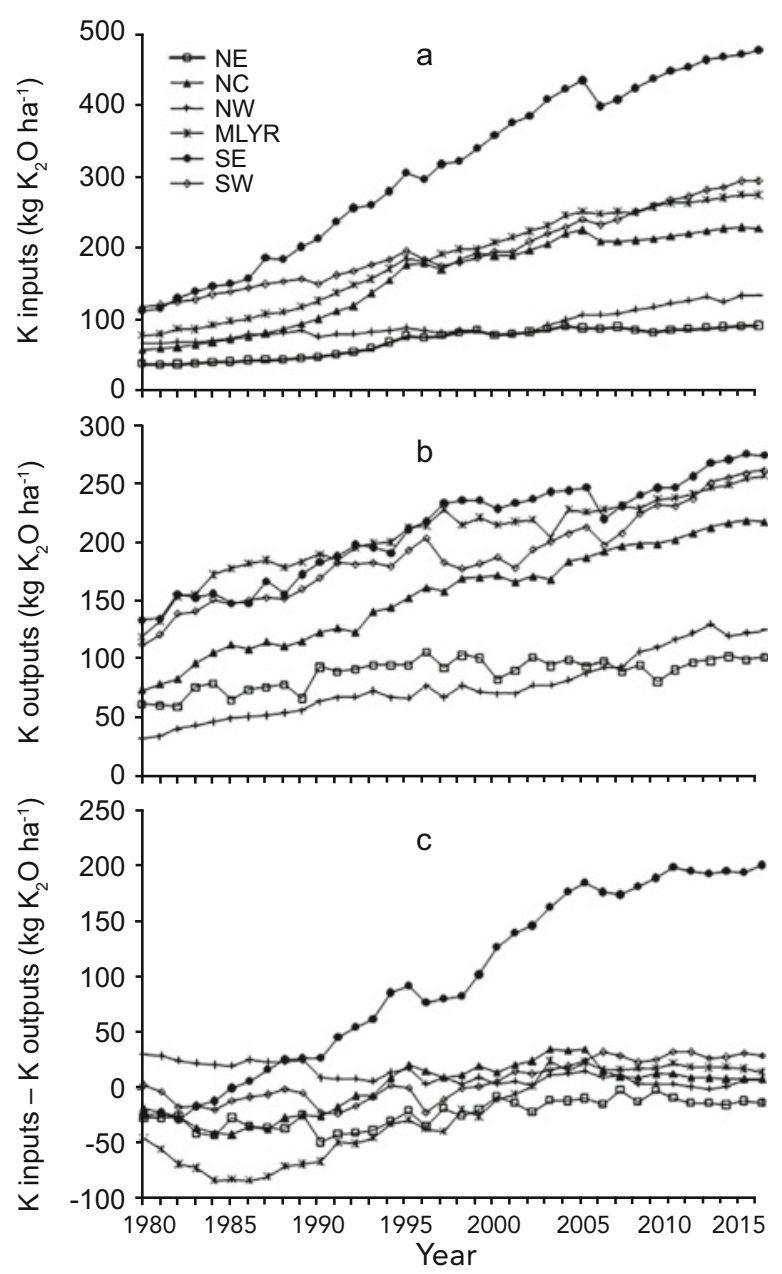

from $-1.5 \mathrm{~kg} \mathrm{~K}_{2} \mathrm{O} \mathrm{ha}^{-1}$ in 1980 to $198 \mathrm{~kg} \mathrm{~K}_{2} \mathrm{O}$ ha $^{-1}$ in 2015 and had the greatest $\mathrm{K}$ surplus of any region (Fig. 11.5). The average $\mathrm{PNBI}_{\mathrm{K}}$ in the 2010s (2010-2015) varied by region: $\mathrm{SW}\left(31.3 \mathrm{~kg} \mathrm{~K}_{2} \mathrm{O} \mathrm{ha}{ }^{-1}\right)>\operatorname{MLYR}\left(15.9 \mathrm{~kg} \mathrm{~K}_{2} \mathrm{O} \mathrm{ha}{ }^{-1}\right)>\mathrm{NC}$ $\left(9.5 \mathrm{~kg} \mathrm{~K}_{2} \mathrm{O} \mathrm{ha}{ }^{-1}\right)>\mathrm{NW}\left(8.2 \mathrm{~kg} \mathrm{~K}_{2} \mathrm{O} \mathrm{ha}{ }^{-1}\right)>\mathrm{NE}\left(-11.9 \mathrm{~kg} \mathrm{~K}_{2} \mathrm{O} \mathrm{ha}^{-1}\right)$. The NE region stayed in deficit for the entire period of assessment (1980-2015). The positive $\mathrm{PNBI}_{\mathrm{K}}$ in the $\mathrm{NW}$ region declined over time. In the $\mathrm{NC}$ region, $\mathrm{PNBI}_{\mathrm{K}}$ increased during the first three decades but declined in the 2010s.

Reliable $\mathrm{K}$ fertilizer use and crop output data, along with information from published peer-reviewed literature, allowed estimation of $\mathrm{K}$ balance in Chinese agriculture. Recent assessments of $\mathrm{K}$ inputs, outputs, and $\mathrm{PNBI}_{\mathrm{K}}$ in China showed significant spatial and temporal differences. Widespread negative $\mathrm{K}$ balances in soils before the 1980s have now changed toward a more positive balance due to increased use of $\mathrm{K}$ fertilizers and retention of crop residues in the field. However, regional and 
crop-specific disparity in $\mathrm{K}$ use provides opportunities to further refine the $\mathrm{K}$ balance through site-specific nutrient management for sustainable crop production systems.

\subsection{India}

India is the second-largest consumer of fertilizer in the world. In nutrient terms, the $2.5 \mathrm{Mt}$ of $\mathrm{K}_{2} \mathrm{O}$ consumed in 2014 was $7.7 \%$ of the global consumption. Alluvial (Inceptisols and Entisols), Red and Lateritic (Alfisols and Ultisols), and Black (Vertisols) soils are dominant soil types in India. The Alluvial soils in the IndoGangetic Plains and elsewhere have ample available and reserve soil K. Despite having high available soil $\mathrm{K}$, the Black soils, mainly in the Central and Western India, often show positive yield responses to added $\mathrm{K}$. This response is most likely due to low $\mathrm{K}$ availability because of relatively higher contents of $\mathrm{Ca}$ and $\mathrm{Mg}$ in these soils. The Red and Lateritic soils in coastal and peninsular India typically have lower $\mathrm{K}$ content. Heffer (2013) estimated that over $60 \%$ of the total $\mathrm{N}+\mathrm{P}_{2} \mathrm{O}_{5}+\mathrm{K}_{2} \mathrm{O}$ is used in cereal crops. Potassium used in cereals is about $50 \%$ of the total consumption. An estimate by Tewatia et al. (2017), using crop production statistics of 2015-2016 and crop nutrient uptake information from multiple sources, showed that removal of $\mathrm{K}_{2} \mathrm{O}$ by cereals is about half of the total $\mathrm{K}$ removed by all crops. The seeming parity between $\mathrm{K}$ applied and removed by cereals, however, is misplaced as the removal of $\mathrm{K}$ by cereals is about 11 times more than the applied $\mathrm{K}$.

\subsubsection{Crop Requirement and Potassium Use}

Post Green Revolution, India's agricultural production was largely driven by inorganic fertilizer use. The demand for crop commodities will rise in the future with population increase and changing food habits. Chand (2007) estimated that 262, 19, 54, and $345 \mathrm{Mt}$ of cereals, pulses, oilseeds, and sugarcane, respectively, would be required in 2020, compared to the base year (2004-2005) production of $193,14,35$, and $262 \mathrm{Mt}$ of the same crops. In 2014-2015, 235, 17, 28, and $363 \mathrm{Mt}$ of cereals, pulses, oilseeds, and sugarcane were produced in India (FAI 2016). A slowdown of crop productivity (Kumar et al. 2004) and decline in PFP (NAAS 2006), however, has been identified as major concerns. Biswas and Sharma (2008) showed that response to applied fertilizer ( $\mathrm{kg}$ grain $\left.[\mathrm{kg} \text { of added } \mathrm{NPK}]^{-1}\right)$ decreased from 13.4 to 3.7 between 1970 and 2005 .

Imbalanced fertilization, more specifically low use of $\mathrm{K}$, has been identified as one of the major reasons for declining PFP in India. Several studies identified inequality between applied $\mathrm{K}$ and its removal in harvested crops, which impacts crop productivity, nutrient use efficiencies, and soil K mining (Naidu et al, 2011; Majumdar et al. 2012, 2016; Singh et al. 2014). Long-term cropping with negative $\mathrm{PNBI}_{\mathrm{K}}$ has been associated with yield declines in the rice-wheat system in South 
Table 11.7 Nutrient uptake from soil reserves under ricewheat cropping system

\begin{tabular}{l|l|l|l}
\hline \multirow{2}{*}{ Location } & \multicolumn{3}{|l}{ K uptake from the soil reserve } \\
\cline { 2 - 4 } & Rice & Wheat & System \\
\cline { 2 - 4 } & $\mathrm{kg} \mathrm{K}_{2} \mathrm{O} \mathrm{ha}^{-1}$ & $\mathrm{~kg} \mathrm{~K}_{2} \mathrm{O} \mathrm{ha}^{-1}$ & $\mathrm{~kg} \mathrm{~K}_{2} \mathrm{O} \mathrm{ha}$ \\
\hline Sabour & 166 & 95 & 261 \\
\hline Ranchi & 127 & 78 & 205 \\
\hline Ludhiana & 211 & 143 & 354 \\
\hline Palampur & 141 & 85 & 226 \\
\hline R.S. Pura & 189 & 112 & 301 \\
\hline Faizabad & 177 & 75 & 252 \\
\hline Kanpur & 146 & 101 & 247 \\
\hline Modipuram & 173 & 121 & 294 \\
\hline Varanasi & 130 & 91 & 221 \\
\hline Pantnagar & 122 & 98 & 220 \\
\hline Mean & 158 & 100 & 258 \\
\hline
\end{tabular}

Tiwari et al. (2006)

arice (Oryza sativa L.); wheat (Triticum aestivum L.)

Asia (Regmi et al. 2002). Potassium partial nutrient balance intensities were negative even with recommended fertilizer application rates of $\mathrm{K}$ and were least negative when farmyard manure was a nutrient source or wheat residues were returned to the field. Although the K-supplying capacity of illite-dominated alluvial soils of the Indo-Gangetic Plains is relatively high (Dobermann et al. 1996), long-term intensive cropping with inadequate application of $\mathrm{K}$ have been associated with large negative $\mathrm{PNBI}_{\mathrm{K}}$ and depletion of native $\mathrm{K}$ reserves (Gami et al. 2001; Yadvinder-Singh et al. 2004). Multi-location studies in the rice-wheat system indicated that soil reserves contributed on an average $258 \mathrm{~kg} \mathrm{~K}_{2} \mathrm{O}$ in $\mathrm{K}$ omission plots (Tiwari et al. 2006) (Table 11.7). Several researchers have assessed K balances in systematic ways contributing to our understanding at various scales.

\subsubsection{Potassium Balance at the Country Scale}

The K partial nutrient balance intensity in most soils of India was largely negative as crop removal far exceeded $\mathrm{K}$ additions through manures and fertilizers. Tandon (2004) reported an annual negative PNBI of -9.7 Mt of $\mathrm{N}+\mathrm{P}+\mathrm{K}$ in 1999-2000, of which $19 \%$ was N, $12 \%$ was P, and $69 \%$ was K. Satyanarayana and Tewatia (2009) estimated $\mathrm{K}$ balances in major agriculturally important states of India. Besides the major field crops, the authors considered the removal of nutrients by fruits and vegetables in all the states; tea (Camellia sinensis (L.) Kuntze), coffee (Coffea spp.), jute (Corchorus capsularis L.), rubber tree (Hevea brasiliensis (Willd. ex A. Juss.) Müll.Arg.), and other plantation crops in states wherever applicable; and the total production values of commodities were multiplied by the nutrient uptake coefficient to arrive at nutrient removal figures. The authors used crop production, state fertilizer 
Table 11.8 Regional K additions, removal by harvested crops, and $\mathrm{K}$ partial nutrient balance intensity $\left(\mathrm{PNBI}_{\mathrm{K}}\right)$ in India

\begin{tabular}{l|l|l|l}
\hline \multirow{2}{*}{ Region } & Addition & Removal & $\mathrm{PNBI}_{\mathrm{K}}$ \\
\cline { 2 - 4 } & $\mathrm{kt} \mathrm{K}_{2} \mathrm{O}$ & $\mathrm{kt} \mathrm{K}_{2} \mathrm{O}$ & $\mathrm{kt} \mathrm{K}_{2} \mathrm{O}$ \\
\hline Eastern Region & 517.6 & 2428.2 & -1910.6 \\
\hline Western Region & 756.7 & 4579.0 & -3822.3 \\
\hline Northern Region & 918.1 & 3534.0 & -2615.9 \\
\hline Southern Region & 1118.1 & 2447.7 & -1329.6 \\
\hline India & 3310.5 & $12,988.9$ & -9678.4 \\
\hline
\end{tabular}

Source: Satyanarayana and Tewatia (2009)

use, and nutrient uptake coefficients from the Fertilizer Association of India (FAI) database (FAI 2008), as well as baseline information and assumptions on nutrient contribution from sources other than fertilizer, such as organic manures, farmyard manure, crop residues, irrigation water, biological nitrogen fixation for individual states while estimating $\mathrm{PNBI}_{\mathrm{K}}$. Nutrient additions only through fertilizer was used where information on other nutrient sources was not available. The overall negative $\mathrm{K}$ balance was estimated at $9.7 \mathrm{Mt}$, and the western region $(3.8 \mathrm{Mt})$ had the highest share, followed by northern (2.6 Mt), eastern (1.9 Mt), and southern (1.3 Mt) regions (Table 11.8).

Dutta et al. (2013) estimated $\mathrm{PNBI}_{\mathrm{K}}$ in different states of India using the IPNI NuGIS approach (Fixen et al. 2012). The study used the $\mathrm{K}$ addition through inorganic and organic sources and the removal by key crops to estimate the $\mathrm{K}$ budget. The authors used data for fertilizer and the total amount of recoverable manure used in different states from various sources (DAC 2011; FAI 2007, 2011). The amount of manure consumed in each state was multiplied by a coefficient, based on average $\mathrm{K}$ content in recoverable manure, to estimate the $\mathrm{K}_{2} \mathrm{O}$ contribution from organic sources. The $\mathrm{K}_{2} \mathrm{O}$ removal by crops was calculated by multiplying production with $\mathrm{K}_{2} \mathrm{O}$ removal coefficient (GOI 2020; FAI 2007, 2011). The crops considered in this study were rice, wheat, maize, barley, chickpea, pigeon pea (Cajanus cajan (L.) Millsp.), green gram (Vigna radiata (L.) R.Wilczek), lentil (Lens culinaris Medik.), moth bean (Vigna aconitifolia (Jacq.) Marechal), groundnut (Arachis hypogaea L.), sesame (Sesamum indicum L.), mustard (Brassica juncea (L.) Czern.), linseed, (Linum usitatissimum L.) cotton, and sugarcane. The study reported large negative $\mathrm{PNBI}_{\mathrm{K}}$ values in northern, western, and eastern regions (Fig. 11.6). The authors attributed the negative $\mathrm{PNBI}_{\mathrm{K}}$ in most states of India to inadequate application of $\mathrm{K}$, high removal of $\mathrm{K}$ by intensive cropping, and export of crop residues. They cautioned that negative $\mathrm{PNBI}_{\mathrm{K}}$ in soils is not a one-off phenomenon but a recurring one, which will significantly affect the future sustainability of crop production.

Patra et al. (2017), using the national soil health card database, highlighted significant decreases in soil $\mathrm{K}$ concentrations in areas of north-western India that were earlier flagged as areas of high negative $\mathrm{PNBI}_{\mathrm{K}}$ (Fig. 11.6). Recently, Tewatia et al. (2017) did an extensive analysis of nutrient inputs and outputs for all major crops, including food grains and other cereals, pulses, oilseeds, forages, fiber crops, fruits, vegetables, plantation crops, spices, tubers, and sugarcane. The authors used 

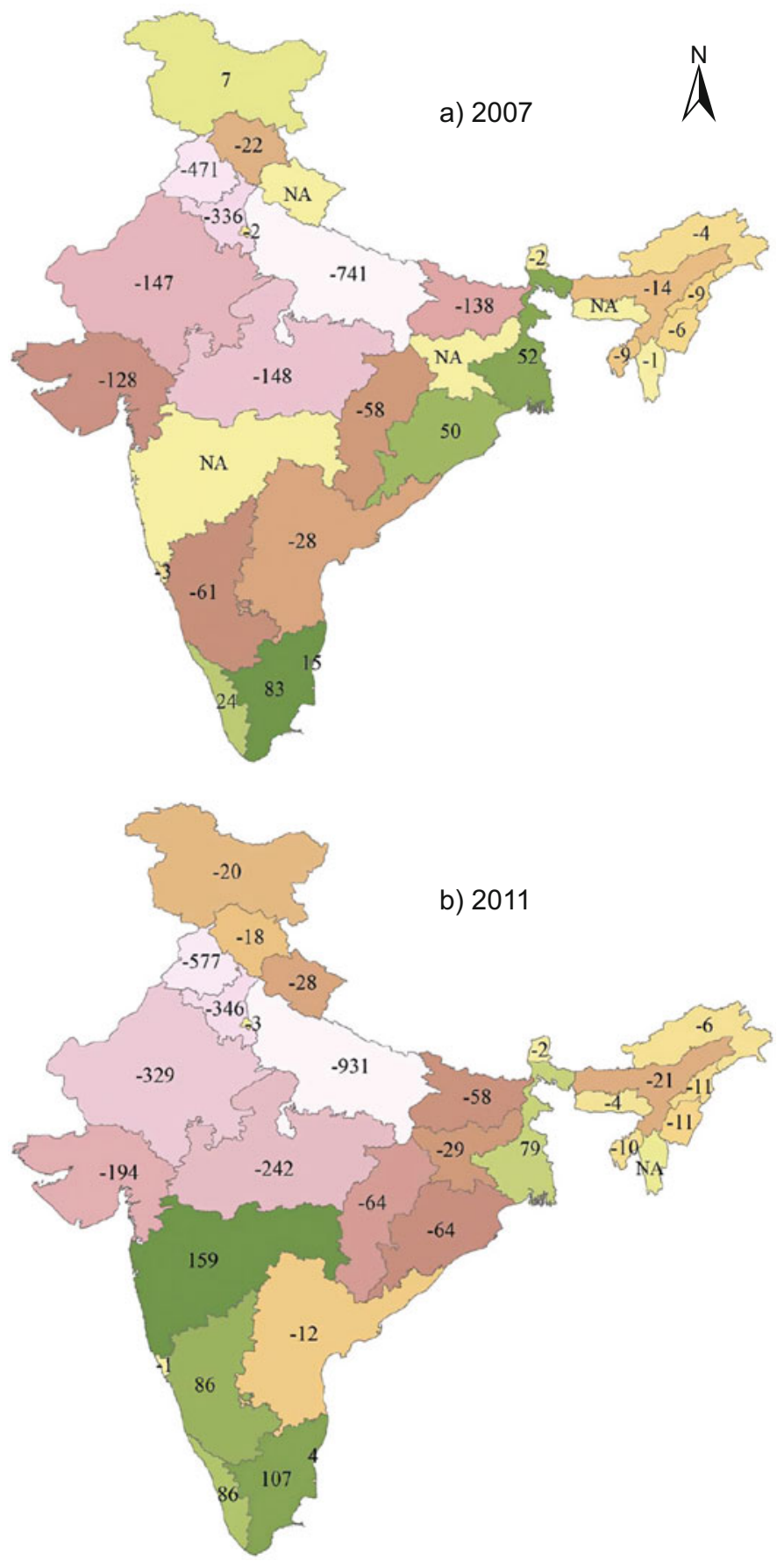

Fig. 11.6 The $\mathrm{PNBI}_{\mathrm{K}}$ for (a) 2007 and (b) 2011 across different states of India. (Dutta et al. 2013) 
Table 11.9 Partial nutrient balance intensities (PNBI) in India for $\mathrm{N}, \mathrm{P}_{2} \mathrm{O}_{5}, \mathrm{~K}_{2} \mathrm{O}$, and total $\left(\mathrm{N}+\mathrm{P}_{2} \mathrm{O}_{5}+\mathrm{K}_{2} \mathrm{O}\right)$. (adapted from Tewatia et al. 2017)

\begin{tabular}{l|l|l|l|l}
\hline Parameter & $\mathrm{N}$ & $\mathrm{P}_{2} \mathrm{O}_{5}$ & $\mathrm{~K}_{2} \mathrm{O}$ & Total \\
\hline Country PNBI (Mt) & -2.3 & -2.1 & -8.6 & -13.0 \\
\hline Average per hectare PNBI across crops $\left(\mathrm{kg} \mathrm{ha}^{-1}\right)$ & -15.3 & -9.4 & -42.2 & -66.9 \\
\hline
\end{tabular}

Source: Modified from Tewatia et al. (2017)

the FAI database for fertilizer consumption and crop production data for 2015 and 2016, and nutrient uptake coefficients were taken from several sources. Only inorganic fertilizer contributions were considered as inputs. The authors calculated a net negative $\mathrm{K}$ balance of $-8.6 \mathrm{Mt}$ of $\mathrm{K}_{2} \mathrm{O}$, which was $66 \%$ of the net negative $\mathrm{N}+\mathrm{P}_{2} \mathrm{O}_{5}+\mathrm{K}_{2} \mathrm{O}$ balance (Table 11.9). The authors further desegregated the $\mathrm{K}$ balance information at a crop and land area basis. The average areal negative balance was $-42.2 \mathrm{~kg} \mathrm{~K}_{2} \mathrm{O} \mathrm{ha}^{-1}$ across all crop groups. It was highest for sugarcane $(-121 \mathrm{~kg}$ $\mathrm{K}_{2} \mathrm{O} \mathrm{ha}^{-1}$ ), fruits $\left(-71 \mathrm{~kg} \mathrm{~K}_{2} \mathrm{O} \mathrm{ha}^{-1}\right)$, and plantation crops $\left(-58 \mathrm{~kg} \mathrm{~K}_{2} \mathrm{O} \mathrm{ha}{ }^{-1}\right)$, while pulses ( $-15 \mathrm{~kg} \mathrm{~K}_{2} \mathrm{O} \mathrm{ha}^{-1}$ ) had the lowest $\mathrm{K}$ deficit, most likely due to low productivity levels. The negative balance in food grains was $-40 \mathrm{~kg} \mathrm{~K}_{2} \mathrm{O}$ ha ${ }^{-1}$; however, it has the most profound effect on $\mathrm{K}$ balance at the national scale as the major food grain crops (rice, wheat, and maize) cover nearly $80 \%$ of the arable land.

\subsubsection{Potassium Balance at the Cropping System Scale}

Cropping systems strongly influence soil nutrient balance. Two or more crops are generally grown in a sequence within a year in much of India, except where climatic or other factors restrict growing multiple crops. Yadav et al. (1998) illustrated how nutrient removal differs by the number of crops grown in sequence and by the type of crops within the cropping system rotation (Table 11.10).

Careful nutrient and crop management planning is necessary for cropping systems to avoid nutrient imbalances in the soil. Long-term intensive cropping with inadequate application of $\mathrm{K}$ results in $\mathrm{K}$ mining leading to large negative balances and depletion of native K reserves (Gami et al. 2001; Regmi et al. 2002; Singh et al. 2002; Yadvinder-Singh et al. 2005; Majumdar et al. 2016). Therefore, adequate input of $\mathrm{K}$ is essential to prevent further depletion of soil K. Fixation of applied $\mathrm{K}$ as non-exchangeable $\mathrm{K}$ is also not ruled out in K-depleted soils. Evidences suggested that the non-exchangeable $\mathrm{K}$ reserves of the mica-rich soils of the Indo-Gangetic Plains (IGP) were exhausted due to continued lack of $\mathrm{K}$ fertilization in intensive cropping, that raised their K fixation capacity (Tiwari et al. 1992; Bijay-Singh et al. 2003). Singh et al. (2018) stated that short-term inconsistencies, if any, in crop response to $\mathrm{K}$ or changes in exchangeable $\mathrm{K}$ content in the soils of the IGP should not guide the $\mathrm{K}$ fertilization decisions. Rather, adequate $\mathrm{K}$ replenishment matching with annual $\mathrm{K}$ removals is required for the long-term sustainability of the rice-maize system in these soils without impairing soil fertility. Soil $\mathrm{K}$ depletion is faster with its 
Table 11.10 Nutrient removal in important cropping systems

\begin{tabular}{l|l|l|l|l}
\hline \multirow{2}{*}{ Crop sequence $^{\mathrm{a}}$} & \multirow{3}{*}{ Total yield $^{\mathrm{b}}$} & \multicolumn{4}{l}{ Total crop nutrient removal } \\
\cline { 2 - 5 } & $\mathrm{N}$ & $\mathrm{P}_{2} \mathrm{O}_{5}$ & $\mathrm{~K}_{2} \mathrm{O}$ \\
\hline Maize-wheat-green gram & $\mathrm{t} \mathrm{ha}^{-1}$ & $\mathrm{~kg} \mathrm{ha}^{-1}$ & $\mathrm{~kg} \mathrm{ha}^{-1}$ & $\mathrm{~kg} \mathrm{ha}^{-1}$ \\
\hline Rice-wheat-green gram & 11.0 & 306 & 27 & 232 \\
\hline Maize-wheat & 7.6 & 328 & 30 & 305 \\
\hline Rice-wheat & 8.8 & 247 & 37 & 243 \\
\hline Maize-wheat & 7.7 & 235 & 40 & 280 \\
\hline Pigeon pea-wheat & 4.8 & 220 & 38 & 206 \\
\hline Pearl millet-wheat-green gram & 10.0 & 219 & 31 & 168 \\
\hline Pearl millet-wheat-cowpea & 19.9 & 278 & 42 & 284 \\
\hline Soybean-wheat & 7.7 & 500 & 59 & 483 \\
\hline Maize-wheat-green gram & 9.0 & 260 & 37 & 170 \\
\hline Maize-rapeseed-wheat & 8.6 & 296 & 47 & 256 \\
\hline
\end{tabular}

${ }^{\mathrm{a}}$ Cowpea (Vigna unguiculata (L.) Walp.); green gram (Vigna radiata (L.) R.Wilczek); maize (Zea mays L.); pearl millet (Pennisetum glaucum (L.) R.Br.); pigeon pea (Cajanus cajan (L.) Millsp.); rapeseed (Brassica napus L.); rice (Oryza sativa L.); soybean (Glycine max (L.) Merr.); wheat (Triticum aestivum $\mathrm{L}$.)

${ }^{\mathrm{b}} \mathrm{Sum}$ of harvested biomass across all crops in the sequence

${ }^{\mathrm{c}} \mathrm{Sum}$ of quantities of nutrients removed in harvested crop portions across all crops in the sequence ${ }^{\mathrm{d}}$ Includes fodder

Table 11.11 Nutrient removal, partial nutrient balance (PNB), and recovery efficiency of $K\left(R_{K}\right)$ under different cropping systems

\begin{tabular}{|c|c|c|c|c|c|c|c|}
\hline \multirow[b]{3}{*}{ Cropping system ${ }^{a}$} & \multicolumn{3}{|c|}{ Nutrient removal } & \multirow{2}{*}{\multicolumn{4}{|c|}{ Partial nutrient balances (PNB) }} \\
\hline & \multirow{2}{*}{\begin{tabular}{|l|}
$\mathrm{N}$ \\
$\mathrm{kg} \mathrm{N} \mathrm{ha}^{-}$ \\
1
\end{tabular}} & \multirow{2}{*}{$\frac{\mathrm{P}}{\mathrm{kg} \mathrm{P} \mathrm{ha}^{-}}$} & \multirow{2}{*}{$\frac{\mathrm{K}}{\mathrm{kg} \mathrm{K} \mathrm{ha}}$} & & & & \\
\hline & & & & $\mathrm{PNB}_{\mathrm{N}}$ & $\mathrm{PNB}_{\mathrm{P}}$ & $\mathrm{PNB}_{\mathrm{K}}$ & $\mathrm{RE}_{\mathrm{K}}$ \\
\hline Rice-wheat & 243 & 41 & 268 & 0.78 & 0.64 & 2.25 & 0.61 \\
\hline Rice-rice & 269 & 47 & 281 & 0.74 & 0.69 & 2.31 & 0.68 \\
\hline Rice-chickpea & 251 & 37 & 185 & 1.32 & 0.62 & 1.95 & 0.77 \\
\hline Rice-potato & 299 & 47 & 208 & 0.88 & 0.65 & 1.30 & 0.72 \\
\hline Maize-wheat & 307 & 64 & 397 & 0.93 & 0.78 & 2.97 & 0.54 \\
\hline Pigeon pea-wheat & 283 & 41 & 201 & 1.17 & 0.65 & 1.63 & 0.73 \\
\hline Sugarcane-ratoon-wheat & 369 & 156 & 547 & 0.92 & 0.76 & 3.56 & 0.69 \\
\hline $\begin{array}{l}\text { Sesbania (GM)-rice- } \\
\text { wheat }\end{array}$ & 245 & 39 & 259 & 0.63 & 0.61 & 1.37 & 0.71 \\
\hline
\end{tabular}

Singh et al. (2002, 2008, 2015a, b)

${ }^{\mathrm{a}}$ Chickpea (Cicer arietinum L.); maize (Zea mays L.); pigeon pea (Cajanus cajan (L.) Millsp.); potato (Solanum tuberosum L.); rice (Oryza sativa L.); sesbania (Sesbania bispinosa (Jacq.) W. Wight); sugarcane (Saccharum giganteum (Walter) Pers.); wheat (Triticum aestivum L.)

continuous inadequate replenishment. It is further aggravated when crops remove more $\mathrm{K}$ than required as luxury consumption. The data presented in Table 11.11 indicate that except for the crop sequences with a pulse or potato as component 
crops, all other sequences remove more $\mathrm{K}$ than $\mathrm{N}$ and $\mathrm{P}$. The higher output: input ratio for $\mathrm{K}$ compared with $\mathrm{N}$ and $\mathrm{P}$ indicated insufficient $\mathrm{K}$ addition under different cropping systems, leading to depletion of soil K (Tiwari et al. 1992; Singh et al. 2015a, b).

Multi-locational studies (Singh et al. 2014) revealed that omission of K in ricewheat cropping system resulted in annual mining of $158-349 \mathrm{~kg} \mathrm{~K} \mathrm{ha}^{-1}$ from soil reserves, and the authors cautioned that continuous inadequate application of $\mathrm{K}$ in this cropping system may not be able to sustain high productivity over time. In a long-term experiment on rice-rice rotations at Gazipur in Central Bangladesh, Mazid Miah et al. (2008) reported that rice grain yield decreased sharply in a clay-loam soil from about $10 \mathrm{t} \mathrm{ha}^{-1}$ in 1985 to $6.2 \mathrm{t} \mathrm{ha}^{-1}$ in 2000 in the $\mathrm{K}$-omission plots, whereas $\mathrm{K}$ application at $50 \mathrm{~kg} \mathrm{ha}^{-1}$ resulted in positive $\mathrm{K}$ balance and maintained rice yields. In another study on rice-wheat rotations in northwest Bangladesh, the application of $54 \mathrm{~kg} \mathrm{~K} \mathrm{ha}^{-1}$ increased average grain yield by $25-30 \%$ of rice and wheat by $53-86 \%$ across a range of demonstration plots on farmers' fields (Mazid Miah et al. 2008). Buresh et al. (2010) showed that near-neutral K balance in rice-wheat cropping systems in India would require 100 and $15 \%$ retention of rice and wheat residues, respectively, when irrigation water contributed $125 \mathrm{~kg} \mathrm{~K} \mathrm{ha}^{-1}$. Replacing winter wheat with maize in the rice-wheat cropping system, with typical crop management practices in India, reduces $\mathrm{PNBI}_{\mathrm{K}}$ well below $-100 \mathrm{~kg} \mathrm{~K}^{-1}$, which becomes even more negative at higher system productivity. At a maize grain yield of $12 \mathrm{tha}^{-1}$, there is a net export of about $200 \mathrm{~kg} \mathrm{~K} \mathrm{ha}^{-1}$, which is often difficult to resupply with external K applications until and unless crop residues are fully returned to the field. Residues are often removed for several reasons. Rice straw has several competitive uses. Maize residue is difficult to manage in the field, and $\mathrm{N}$ immobilization often occurs because of high $\mathrm{C}: \mathrm{N}$ ratios in that residue. Nutrient depletion-replenishment studies in the rice-based systems in Bangladesh have also shown negative $\mathrm{PNBI}_{\mathrm{K}}$ (Timsina et al. 2013).

On-farm results from the AICRP-IFS (2012) showed negative $\mathrm{PNBI}_{\mathrm{K}}$ in farmers' fields across locations and cropping systems (Table 11.12). Potassium partial nutrient balance intensity was influenced by the crops selected in various cropping systems.

The "SR+M" treatment received supplemental application of secondary and micronutrients, along with the same amount of N, P, and K as in "SR" (the state recommendation). The addition of secondary and micronutrients to SR triggered higher removal of $\mathrm{K}$ in most cases, suggesting that the application of limiting secondary and micronutrients, even at suboptimal application of major nutrients, may increase crop yield and removal of $\mathrm{K}$.

The deficit in K supply will cause changes in K soil concentrations. Singh et al. (2013) showed that, in the absence of added $\mathrm{K}$ fertilizer, average exchangeable and non-exchangeable $\mathrm{K}$ decreased by $13-18 \mathrm{mg} \mathrm{kg}^{-1}$ and $26-41 \mathrm{mg} \mathrm{kg}^{-1}$, respectively, across 60 on-farm locations during one rice-wheat cropping cycle. Another study assessing spatial variation of different soil $\mathrm{K}$ fractions in an intensively cultivated region of West Bengal (Chatterjee et al. 2015) associated the low non-exchangeable $\mathrm{K}$ in parts of the study area with high $\mathrm{K}$ removal exceeding $\mathrm{K}$ application rates in banana (Musa spp.) plantations. Non-exchangeable $\mathrm{K}$ is not measured in routine soil 
Table 11.12 Potassium nutrient balance intensity $\left(\mathrm{PNBI}_{\mathrm{K}}\right)$ for several cropping systems

\begin{tabular}{|c|c|c|c|c|}
\hline \multirow[b]{2}{*}{ Cropping system $^{\mathrm{a}}$} & \multirow[b]{2}{*}{ Treatment } & $\mathrm{K}_{2} \mathrm{O}$ addition & $\mathrm{K}_{2} \mathrm{O}$ removal & $\mathrm{PNBI}_{\mathrm{K}}$ \\
\hline & & $\mathrm{kg} \mathrm{K}_{2} \mathrm{O} \mathrm{ha}{ }^{-1}$ & $\mathrm{~kg} \mathrm{~K}_{2} \mathrm{O} \mathrm{ha}{ }^{-1}$ & $\mathrm{~kg} \mathrm{~K}_{2} \mathrm{O} \mathrm{ha}{ }^{-1}$ \\
\hline \multirow{3}{*}{$\begin{array}{l}\text { Rice-wheat } \\
\text { (24) }\end{array}$} & FFP & 0.0 & 150.0 & -150.0 \\
\hline & SR & 74.7 & 160.0 & -85.3 \\
\hline & $\mathrm{SR}+\mathrm{M}$ & 74.7 & 174.0 & -99.3 \\
\hline \multirow{3}{*}{$\begin{array}{l}\text { Rice-rice } \\
(24)\end{array}$} & FFP & 70.6 & 172.0 & -101.5 \\
\hline & SR & 66.4 & 189.0 & -135.6 \\
\hline & $\mathrm{SR}+\mathrm{M}$ & 66.4 & 202.0 & -135.6 \\
\hline \multirow[t]{3}{*}{ Pearl millet-mustard (18) } & FFP & 0.0 & 104.0 & -104.0 \\
\hline & SR & 54.0 & 116.0 & -62.1 \\
\hline & $\mathrm{SR}+\mathrm{M}$ & 54.0 & 122.0 & -65.1 \\
\hline \multirow[t]{3}{*}{ Pearl millet-wheat (18) } & FFP & 0.0 & 65.0 & -65.0 \\
\hline & SR & 83.0 & 95.0 & -12.0 \\
\hline & $\mathrm{SR}+\mathrm{M}$ & 83.0 & 101.0 & -18.0 \\
\hline \multirow[t]{3}{*}{ Maize-Bengal gram (24) } & FFP & 0.0 & 133.0 & -133.0 \\
\hline & SR & 20.8 & 169.0 & -148.3 \\
\hline & $\mathrm{SR}+\mathrm{M}$ & 20.8 & 181.0 & -160.3 \\
\hline \multirow[t]{3}{*}{ Rice-green gram(18) } & FFP & 34.0 & 129.0 & -95.0 \\
\hline & SR & 66.4 & 161.0 & -94.6 \\
\hline & $\mathrm{SR}+\mathrm{M}$ & 66.4 & 176.0 & -109.6 \\
\hline \multirow[t]{3}{*}{ Maize-wheat(18) } & FFP & 21.6 & 53.0 & -31.4 \\
\hline & SR & 58.1 & 89.0 & -30.9 \\
\hline & $\mathrm{SR}+\mathrm{M}$ & 58.1 & 97.0 & -38.9 \\
\hline \multirow[t]{3}{*}{ Cotton-pearl millet (18) } & FFP & 0.0 & 85.0 & -85.0 \\
\hline & SR & 83.0 & 91.0 & -8.0 \\
\hline & $\mathrm{SR}+\mathrm{M}$ & 83.0 & 102.0 & -19.0 \\
\hline
\end{tabular}

FFP, farmers' fertilization practice; SR, state recommendation; $\mathrm{SR}+\mathrm{M}$, state recommendation with additional micro- and secondary nutrients

Modified from AICRP-IFS (2012)

${ }^{a}$ Bengal gram (Cicer arietinum L.); cotton (Gossypium hirsutum L.); green gram (Vigna radiata (L.) R.Wilczek); maize (Zea mays L.); mustard (Brassica juncea (L.) Czern.); pearl millet (Pennisetum glaucum (L.) R.Br.); rice (Oryza sativa L.); wheat (Triticum aestivum L.); values in parenthesis are the number of trials

tests in most countries, including India, and any decline in this $\mathrm{K}$ fraction generally remains unnoticed.

In conclusion, high-resolution and high-quality data are available to assess $\mathrm{K}$ or other nutrient balances in India. Several assessments at national and cropping system scales showed that $\mathrm{K}$ balances are largely negative. Low application rates of $\mathrm{K}$ in crops combined with high offtake of $\mathrm{K}$ at harvest due to straw and other crop residue removal from farms are the major reasons. The on-farm studies showed declines in exchangeable and non-exchangeable $\mathrm{K}$ fractions in soils of intensively cultivated areas. Potassium fertilization decisions based on agronomic evidence are required to improve crop yields and farm profitability and to maintain $\mathrm{K}$ fertility of Indian soils. 


\subsection{Sub-Saharan Africa}

Soil fertility depletion is considered one of the major factors limiting crop production in sub-Saharan Africa. Crop production in soils of low native fertility with little or no fertilizer application is depleting and unsustainable. Maintaining the productive capacity of these soils through effective nutrient management remains a major challenge. Nutrient mass balance in specific soil-crop systems is a reliable indicator of nutrient depletion or mining.

When estimated at different spatial scales, nutrient balances provide insight into sustainability challenges affecting production systems in the short- and long-term. Access, price, and affordability of fertilizers are major production constraints in Sub-Saharan Africa, especially for K fertilizers. The following sections outline the K balance at various spatial scales in the region and how that affects crop productivity in different production systems.

\subsubsection{Potassium Balance at Continental and Country Scales}

Analysis of nutrient balances in sub-Saharan Africa shows consistent negative trends that result from the continuous cultivation of crops for many decades with little addition of nutrient inputs in agricultural soils in the region. Annual $\mathrm{PNBI}_{\mathrm{K}}$ at the regional level averages less than $-15 \mathrm{~kg} \mathrm{~K} \mathrm{ha}^{-1}$ and ranges between -5 and $-45 \mathrm{~kg} \mathrm{~K}$ $\mathrm{ha}^{-1}$ for various countries (Stoorvogel et al. 1993; Van den Bosch et al. 1998) (Fig. 11.7). The losses of $\mathrm{K}$ from the soil translate to about $3 \mathrm{Mt} \mathrm{K}$ year $^{-1}$. The average fertilizer use of $18 \mathrm{~kg} \mathrm{ha}^{-1}$ of $\mathrm{N}+\mathrm{P}+\mathrm{K}$ in sub-Saharan Africa is the lowest in the world, accounting for less than $2 \%$ of the world fertilizer consumption. This is far below requirements to prevent nutrient depletion. Potassium inputs from fertilizer are proportionally lower than $\mathrm{N}$ and $\mathrm{P}$, as most fertilizers that are recommended and used in crop production in sub-Saharan Africa exclude K. As a result, the amounts of $\mathrm{K}$ applied as fertilizer are less than $3 \mathrm{~kg} \mathrm{ha}^{-1}$. The application of $\mathrm{K}$ through organic resources is also limited and negligible due to low amounts of manures and crop residues that are available. The removal of $\mathrm{K}$ in grain and crop residues and $\mathrm{K}$ losses through erosion and leaching combine to result in severe nutrient depletion. The average yield of cereal crops which covers $80 \%$ of croplands is about $1.5 \mathrm{t} \mathrm{ha}^{-1}$, accounting for removal of $20-30 \mathrm{~kg} \mathrm{~K} \mathrm{ha}^{-1}$. Potassium losses due only to erosion in sub-Saharan Africa range from 3 to $15 \mathrm{~kg}$ of $\mathrm{N}+\mathrm{P}+\mathrm{K} \mathrm{ha} \mathrm{hear}^{-1}$ (Henao and Baanante 2006).

Despite the overall large negative $\mathrm{PNBI}_{\mathrm{K}}$ in sub-Saharan Africa, nutrient balances vary greatly among different cropping systems and agro-ecological zones. The largest losses of $20-50 \mathrm{~kg} \mathrm{~K} \mathrm{ha}^{-1}$ year $^{-1}$ occur in the sub-humid savannahs of West Africa and the highlands and sub-humid areas of east Africa and southern Africa, a region with high potential for crop production and high population densities. Moderate $\mathrm{K}$ losses of $10-20 \mathrm{~kg} \mathrm{~K} \mathrm{ha}^{-1}$ year $^{-1}$ occur in the humid forests and 


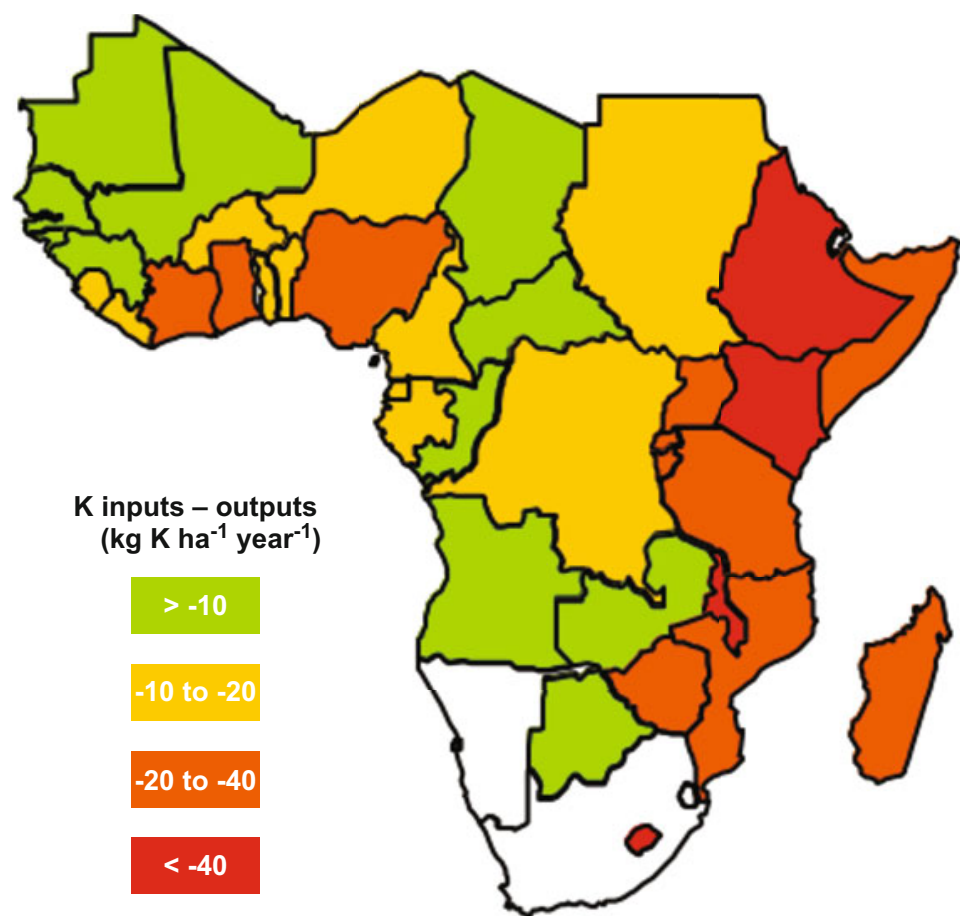

Fig. 11.7 Potassium balances for countries in sub-Saharan Africa. (adapted from Henao and Baanante 2006)

wetlands of south-central Africa and Sudan. The soils in the arid zones in southern and West Africa have the lowest $\mathrm{K}$ losses (5-15 $\mathrm{kg} \mathrm{K} \mathrm{ha}^{-1} \mathrm{year}^{-1}$ ), mainly due to low nutrient removals from low yields.

\subsubsection{Potassium Balance at the Regional Scale}

Potassium partial nutrient balance intensities for regions within countries are highly variable, similar to the patterns of $\mathrm{K}$ balances at the continental level. For example, $\mathrm{PNBI}_{\mathrm{K}}$ levels in Kenya are consistently negative, and range from -5 to $-34 \mathrm{~kg} \mathrm{~K} \mathrm{ha}^{-1}$ year $^{-1}$ (Henao and Baanante 2006) (Table 11.13). The Rift Valley region with the lowest balances is characterized by high potential crop production and intensive cultivation, while the highest nutrient balances in northeastern Kenya is associated with arid conditions that result in both low crop yields and nutrient removals. Relatively higher K fertilizer use in the central Kenya Rift Valley is due to large areas of tea, coffee, and sugarcane production that receive recommended fertilizers containing $\mathrm{K}$. 
Table 11.13 Regional K partial nutrient balance intensity $\left(\mathrm{PNBI}_{\mathrm{K}}\right)$ levels in Kenya

\begin{tabular}{|c|c|c|c|c|}
\hline \multirow[b]{3}{*}{ Region } & \multirow{2}{*}{\begin{tabular}{|l} 
K removal \\
Crop removal \\
\end{tabular}} & \multicolumn{2}{|l|}{$\mathrm{K}$ added } & \multirow[b]{2}{*}{$\mathrm{PNBI}_{\mathrm{K}}$} \\
\hline & & K fertilizer & Manure & \\
\hline & $\mathrm{kg} \mathrm{K} \mathrm{ha}^{-1}$ year $^{-1}$ & $\mathrm{~kg} \mathrm{~K} \mathrm{ha}^{-1}$ year $^{-1}$ & $\mathrm{~kg} \mathrm{~K} \mathrm{ha}^{-1}$ year $^{-1}$ & $\mathrm{~kg} \mathrm{~K} \mathrm{ha}^{-1}$ year $^{-1}$ \\
\hline Central & 20 & 8 & 3 & -9 \\
\hline Coast & 21 & - & 1 & -20 \\
\hline Eastern & 22 & 1 & 1 & -20 \\
\hline Nairobi & 11 & 2 & 1 & -8 \\
\hline North Eastern & 6 & - & 1 & -5 \\
\hline Nyanza & 27 & 2 & 1 & -24 \\
\hline Rift Valley & 40 & 5 & 1 & -34 \\
\hline Western & 25 & 3 & 2 & -20 \\
\hline
\end{tabular}

Henao and Baanante (2006)

\subsubsection{Potassium Balance at the Farm Scale}

Aggregated nutrient balance estimates at national and regional levels for sub-Saharan Africa have shown overall large negative balances. At such scales, variability is driven by soil-forming factors, such as the underlying geology and position on the landscape, jointly termed the "soilscape" (Deckers 2002). In contrast, variation in soil fertility associated with resource management at the farm level has generally been overlooked, despite evidence that such operations affect $\mathrm{K}$ balances and productivity of both crops and livestock (Smaling and Braun 1996; Giller et al. 2006). In addition, there are strong indications that $K$ balances differ widely among farms in different wealth categories and among plots at different distances from homesteads (Shepherd and Soule 1998).

Differences in access to fertilizer by farmers contribute significantly to the variability of fertilizer use. Farmers with more access to fertilizer use greater amounts of mineral fertilizers (Tittonell et al. 2005) and tend to own more cattle and thus manure, thereby using significant quantities of nutrients (Swift et al. 1989; Achard and Banoin 2003). Consequently, $\mathrm{K}$ accumulates on farms with more access to resources, often at the expense of the poorer farms.

Within farms, soil fertility status of different plots on smallholder farms in sub-Saharan Africa may vary considerably due to both inherent factors and different resource management strategies (Tittonell et al. 2005). Smallholder farms consist of multiple plots managed differently in terms of allocation of crops, fertilizers, and labor resources, resulting in within-farm soil fertility gradients caused by management strategies a common feature (Zingore et al. 2007). In most cases, both organic and mineral fertilizer resources are preferentially allocated to the part of the farm used for growing the main food-security crop, often close to the homestead, while plots further away are neglected. Such management decisions culminate in the creation of gradients of decreasing soil fertility with distance from the homestead (Elias et al. 1998; Vanlauwe et al. 2002). Even where small quantities of manure and mineral fertilizers are available, farmers still apply them at high rates by 
concentrating them in small areas. For instance, farmers in Zimbabwe apply cattle manure at amounts as high as $80 \mathrm{t} \mathrm{ha}^{-1}$ year $^{-1}$ by concentrating cattle manure on preferred plots (Mugwira and Murwira 1998). The underlying reasons for targeting of nutrient resources to few fields are not fully understood, but important factors include farm size, distance of different plots from the homestead, restricted availability of fertilizers and manures, availability and efficiency of labor use, risk of theft, and the need to reduce the risk associated with erratic rainfall (Nkonya et al. 2005).

Potassium application in African agriculture is low. Most of the farmland in Africa is dependent on soils that experienced some level of erosion and nutrient mining. The exchangeable $\mathrm{K}$ concentrations of the soil are generally low because of the high degree of weathering and a long history of crop production without proper soil management. Farmers' wealth, resource management strategies, and access to K fertilizers all contribute to significant variation in largely negative $\mathrm{K}$ balances across African soils. Improved access to $\mathrm{K}$ fertilizers and their site-specific management are key to increasing or even just maintaining the productive capacity of these soils.

\subsection{North Africa}

The North Africa region is dominated by the Mediterranean climate, with rainfall during the colder winter and dry and hot during the summer. The soils of this region are varied but generally low in organic matter. In arable lands, the predominant soils are calcimagnesic, fersialitic, and clay-rich vertisols. Major land areas of North Africa are under arid and semi-arid climate zones. Although lack of sufficient rainfall is the main limitation of crop production, nutrient deficiencies also limit crop productivity. Even though most of the research undertaken in North Africa in the 1980s reported that soils are well supplied with K (Ghanem et al. 1983; El Oumri 1985; Stitou 1985), continuous withdrawal of soil $\mathrm{K}$ has led to a decline in soil fertility. Several areas in North Africa now report low exchangeable $\mathrm{K}$ and high spatial variability of $\mathrm{K}$ in soils (Badraoui et al. 2003). As $\mathrm{K}$ availability in soils of most North African countries (Morocco, Algeria, and Tunisia) is perceived to be generally adequate (Azzaoui et al. 1993; Mhiri 2002; Belouchrani et al. 2002), fertilizer $\mathrm{K}$ consumption has remained very low, with an average of $12 \%$ of the total consumed N, P, and K (FAOSTAT 2018). Potassium partial nutrient balance intensities show negative trends due to crop $\mathrm{K}$ removal with none or low $\mathrm{K}$ inputs. In some rainfed areas, farmers do not fertilize crops with $\mathrm{K}$, even when it is required, due to the relatively high cost of fertilizer, which has led to visible $\mathrm{K}$ deficiency symptoms in crops in the last few decades (Mhiri 2002). For wheat, the main annual crop of the region, fertilizer recommendations are based mainly on $\mathrm{N}$ and $\mathrm{P}$, while $\mathrm{K}$ application is generally neglected. Research on $\mathrm{K}$ also became limited in the last decades with the most recent research programs on $\mathrm{K}$ undertaken more than 30 years ago. 
Table 11.14 Cumulative $\mathrm{K}$ partial nutrient balances $\left(\mathrm{PNBI}_{\mathrm{K}}\right)$ of cropping systems at different locations in Morocco

\begin{tabular}{|c|c|c|c|c|c|}
\hline \multirow[b]{2}{*}{$\begin{array}{l}\text { Crop rotations } \\
\text { (location) }^{\mathrm{a}}\end{array}$} & \multirow[b]{2}{*}{$\begin{array}{l}\text { Study } \\
\text { years }\end{array}$} & \multirow[b]{2}{*}{$\begin{array}{l}\mathrm{K} \\
\text { application }\end{array}$} & $\begin{array}{l}\text { Cumulative } \mathrm{K} \\
\text { fertilizer addition }^{\mathrm{b}}\end{array}$ & $\begin{array}{l}\text { Cumulative } \\
\mathrm{K} \text { removal }^{\mathrm{c}}\end{array}$ & $\mathrm{PNBI}_{\mathrm{K}}$ \\
\hline & & & $\mathrm{kg} \mathrm{K} \mathrm{ha}^{-1}$ & $\mathrm{~kg} \mathrm{~K} \mathrm{ha}^{-1}$ & $\begin{array}{l}\mathrm{kg} \mathrm{K} \\
\mathrm{ha}^{-1}\end{array}$ \\
\hline $\begin{array}{l}\text { Wheat-maize-forage- } \\
\text { cotton-sugar beet }\end{array}$ & 12 & $-\mathrm{K}$ & 0 & 1645 & -1645 \\
\hline $\begin{array}{l}\text { (Sidi Kacem, } \\
\text { Morocco) }\end{array}$ & 12 & $+\mathrm{K}$ & 1380 & 1646 & -266 \\
\hline Wheat-legumes & 15 & $-\mathrm{K}$ & 0 & 521 & -521 \\
\hline $\begin{array}{l}\text { (Mohammedia, } \\
\text { Morocco) }\end{array}$ & 15 & $+\mathrm{K}$ & 1320 & 555 & 765 \\
\hline $\begin{array}{l}\text { Wheat-maize-forage- } \\
\text { cotton-sugar beet }\end{array}$ & 16 & $-\mathrm{K}$ & 0 & 9479 & -9479 \\
\hline (Tessaout, Morocco) & 16 & $+\mathrm{K}$ & 2520 & 9721 & -7201 \\
\hline $\begin{array}{l}\text { Wheat-maize-forage- } \\
\text { cotton-sugar beet }\end{array}$ & 14 & $-\mathrm{K}$ & 0 & 5863 & -5863 \\
\hline (Souihla, Morocco) & 14 & $+\mathrm{K}$ & 2320 & 6086 & -3766 \\
\hline $\begin{array}{l}\text { Wheat-maize-forage- } \\
\text { cotton-sugar beet }\end{array}$ & 17 & $-\mathrm{K}$ & 0 & 6457 & -6457 \\
\hline (Afourer, Morocco) & 17 & $+\mathrm{K}$ & 2640 & 6450 & -3810 \\
\hline $\begin{array}{l}\text { Wheat-maize-forage- } \\
\text { cotton-sugar beet }\end{array}$ & 10 & $-\mathrm{K}$ & 0 & 5406 & -5406 \\
\hline $\begin{array}{l}\text { (Boulaouane, } \\
\text { Morocco) }\end{array}$ & 10 & $+\mathrm{K}$ & 2680 & 5416 & -2736 \\
\hline Potato-wheat-onion & 10 & $-\mathrm{K}$ & 0 & 516 & -516 \\
\hline $\begin{array}{l}\text { (Dar Bouazza, } \\
\text { Morocco) }\end{array}$ & 10 & $+\mathrm{K}$ & 1800 & 455 & 1345 \\
\hline
\end{tabular}

Azzaoui and Alilou (1990)

${ }^{\mathrm{a} C}$ Cotton (Gossypium hirsutum L.); forage (barley, ryegrass, vetch) legumes (pulses); maize (Zea mays L.); onion (Allium cepa L.); potato (Solanum tuberosum L.); sugar beet (Beta vulgaris L.); wheat (Triticum aestivum L.)

${ }^{\mathrm{b}} \mathrm{Sum}$ of $\mathrm{K}$ applications across all years

${ }^{\mathrm{c}} \mathrm{Sum}$ of $\mathrm{K}$ removed in harvested crop portions across all years

Limited information showed negative $\mathrm{PNBI}_{\mathrm{K}}$ levels in Morocco across locations and cropping systems (Table 11.14). In only two cases (the wheat-legume rotation in Mohammedia and the potato-wheat-onion (Allium cepa L.) rotation in Dar-Bouazza) was $\mathrm{K}$ added in quantities large enough to produce positive $\mathrm{PNBI}_{\mathrm{K}}$. A similar study in the Saharan region of Algeria showed positive $\mathrm{PNBI}_{\mathrm{K}}$ levels when $\mathrm{K}$ was added in an irrigated wheat production system (Table 11.15). Since the K balance in these studies accounted only for $\mathrm{K}$ output by grain removal, greater $\mathrm{K}$ deficits would be expected in areas where wheat straw is also removed from the field for off-farm use. Previous research demonstrated that critical levels of $\mathrm{K}$ in soils depends on soil types and crop yield performances (Badraoui et al. 2002; Aissa and Mhiri 2002). There are large differences in $K$ use between rainfed and irrigated areas. 
Table 11.15 Potassium partial nutrient balance intensity $\left(\mathrm{PNBI}_{\mathrm{K}}\right)$ of irrigated wheat in sandy soils of the Saharan area (South Ouargla) of Algeria

\begin{tabular}{c|l|c}
\hline $\mathrm{K}$ addition & $\mathrm{K}$ removal in grain $^{-1}$ & $\mathrm{PNBI}_{\mathrm{K}}$ \\
\hline $\mathrm{kg} \mathrm{K} \mathrm{ha}^{-1}$ & $\mathrm{~kg} \mathrm{~K} \mathrm{ha}^{-1}$ & $\mathrm{~kg} \mathrm{~K} \mathrm{ha}^{-1}$ \\
\hline 0 & 13.86 & -13.86 \\
\hline 60 & 22.13 & 38.87 \\
\hline 120 & 31.27 & 88.73 \\
\hline 180 & 38.66 & 142.34 \\
\hline
\end{tabular}

Halilat (2004)

The expansion of irrigated area in North Africa due to incentive programs such as the Green Plan in Morocco and the National Program for Rural and Agricultural Development (PNDAR) in Algeria intensified production and increased $\mathrm{K}$ removal by crops. As a consequence, growers in irrigated areas use more $\mathrm{K}$ for industrial crops, fruits, and vegetables. In the citrus sector, which represents one of the main export crops in the region, $\mathrm{K}$ plays an important role in fruit quality (Hamza et al. 2012). For irrigated wheat, research undertaken in the Doukkala region of Morocco showed that wheat responded to added $\mathrm{K}$ fertilizer only when the yield was higher than $5 \mathrm{t} \mathrm{ha}^{-1}$ (Badraoui et al. 2002). The highest consumers of $\mathrm{K}$ fertilizer are greenhouse crop production systems. For example, banana production uses on average of $500 \mathrm{~kg} \mathrm{~K}_{2} \mathrm{O} \mathrm{ha}{ }^{-1}$, strawberry production uses $400 \mathrm{~kg} \mathrm{~K}_{2} \mathrm{O} \mathrm{ha}{ }^{-1}$, pepper (Capsicum spp.) production uses $140 \mathrm{~kg} \mathrm{~K}_{2} \mathrm{O} \mathrm{ha}{ }^{-1}$, and potato production uses $115 \mathrm{~kg} \mathrm{~K}_{2} \mathrm{O} \mathrm{ha}^{-1}$ in northwest Morocco (Zerouali and Mrini 2004).

In Tunisia, the status of $\mathrm{K}$ in soils differs among three soil categories (Mhiri 2002): (1) acidic soils in the northwest are generally low in K; (2) alkaline, calcareous, fine-textured soils located in the north are rich in total and exchangeable $\mathrm{K}$, and are considered among the most fertile soils in the country; and (3) alkaline, calcareous coarse-textured soils, located in the center and south of the country and the Sahel, are relatively low to very low in exchangeable K.

In Algeria, arable land is limited to less than $3 \%$ of the total geographical area. Approximately 8.7 Mha are available to grow cash crops, forest, pasture, rangelands, and scrub and alfalfa (Laoubi and Yamao 2012). The consumption of K fertilizer in Algeria is low and represents about $11 \%$ of the total consumed N, P, and K fertilizer in the country (FAOSTAT 2018).

There are few studies on $\mathrm{K}$ mass balance in Morocco, Algeria, and Tunisia. Potassium fertilizers are applied in limited quantities due to perceived high native $\mathrm{K}$ in soils. Potassium deficiency in crops, however, is increasing due to higher removal of $\mathrm{K}$ in intensive agricultural production systems with improved irrigation facilities. Research evidence of better crop productivity and quality with site-specific $\mathrm{K}$ management in the region suggests the need for higher levels of $\mathrm{K}$ inputs to crops. 


\subsection{United States}

Potassium budgets for the USA were calculated using the NuGIS model (Fixen et al. 2012). The model calculates $\mathrm{K}$ budgets for each county in each state for 1987, 1992, 1997, 2002, 2007, 2010, 2011, and 2012. Briefly, the NuGIS model considers the sum of nutrient removal by up to 21 major crops as the only output: alfalfa (Medicago sativa L.), apple (Malus domestica Borkh.), barley, common bean (Phaseolus vulgaris L.), canola, maize grain, maize silage, cotton, hay (various crops other than alfalfa), orange (Citrus sinensis (L.) Osbeck), peanut (Arachis hypogaea L.), potato, rice, sorghum, soybean, sugar beet, sugarcane, sunflower, sweet corn (Zea mays L.), tobacco, and wheat. The model uses crop-specific $\mathrm{K}$ removal rates ( $\mathrm{g} \mathrm{K} \mathrm{kg}^{-1}$ yield) and does not consider spatiotemporal variability. The nutrient inputs considered by the model are fertilizer and manure.

A map $\mathrm{PNB}_{\mathrm{K}}$ for the contiguous 48 states of the USA is shown in Fig. 11.8. A $\mathrm{PNB}_{\mathrm{K}}>1$ dominates the more arid western half of the USA where soil $\mathrm{K}$ levels have historically been higher and where $\mathrm{K}$ application rates have generally been lower.

Based on the distribution of $\mathrm{PNB}_{\mathrm{K}}$ (Fig. 11.8), the USA was divided into four groups, and trends in $\mathrm{PNB}_{\mathrm{K}}$ over time were assessed (Fig. 11.9). Temporal trends were evaluated through linear regression of the $\log$ of $\mathrm{PNB}_{\mathrm{K}}$ calculated for each regional group as well as for the USA. For the 48 contiguous states considered as a
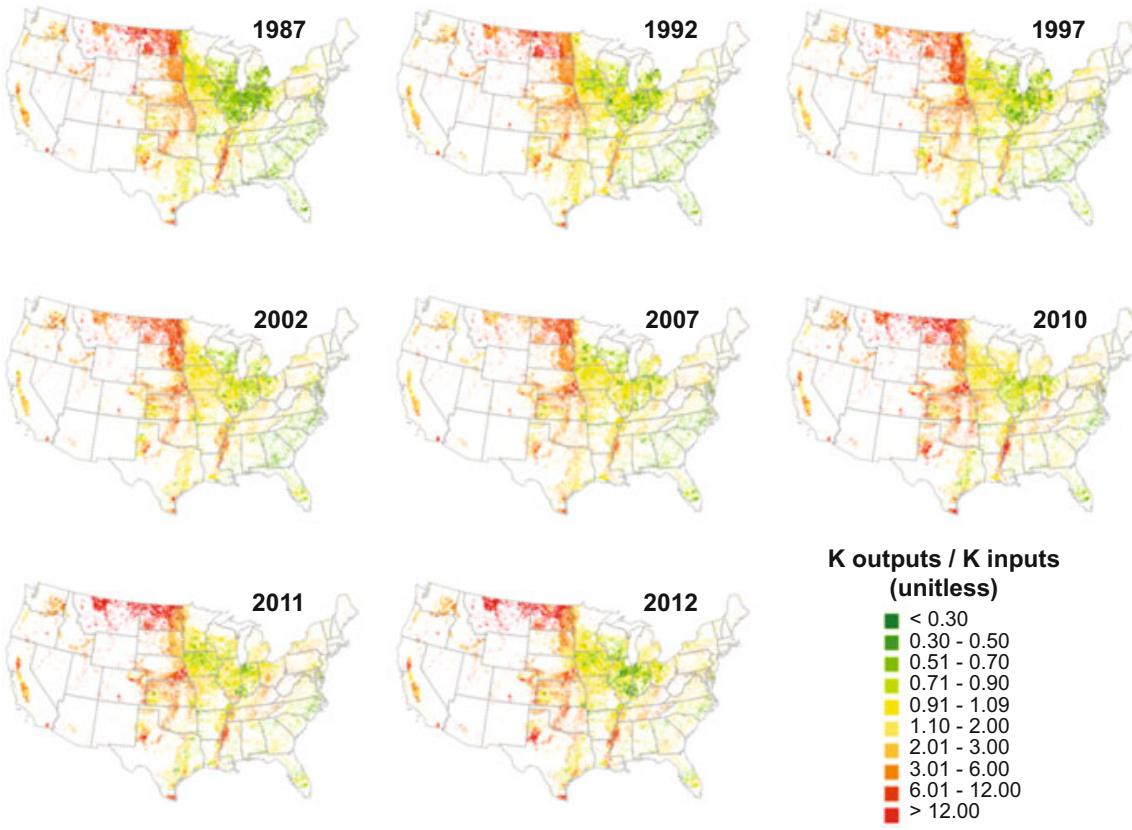

Fig. 11.8 Potassium partial nutrient balance $\left(\mathrm{PNB}_{\mathrm{K}}\right)$ for the contiguous 48 states of the USA for years 1987, 1992, 1997, 2002, 2007, 2010, 2011, and 2012 as calculated by the NuGIS model 


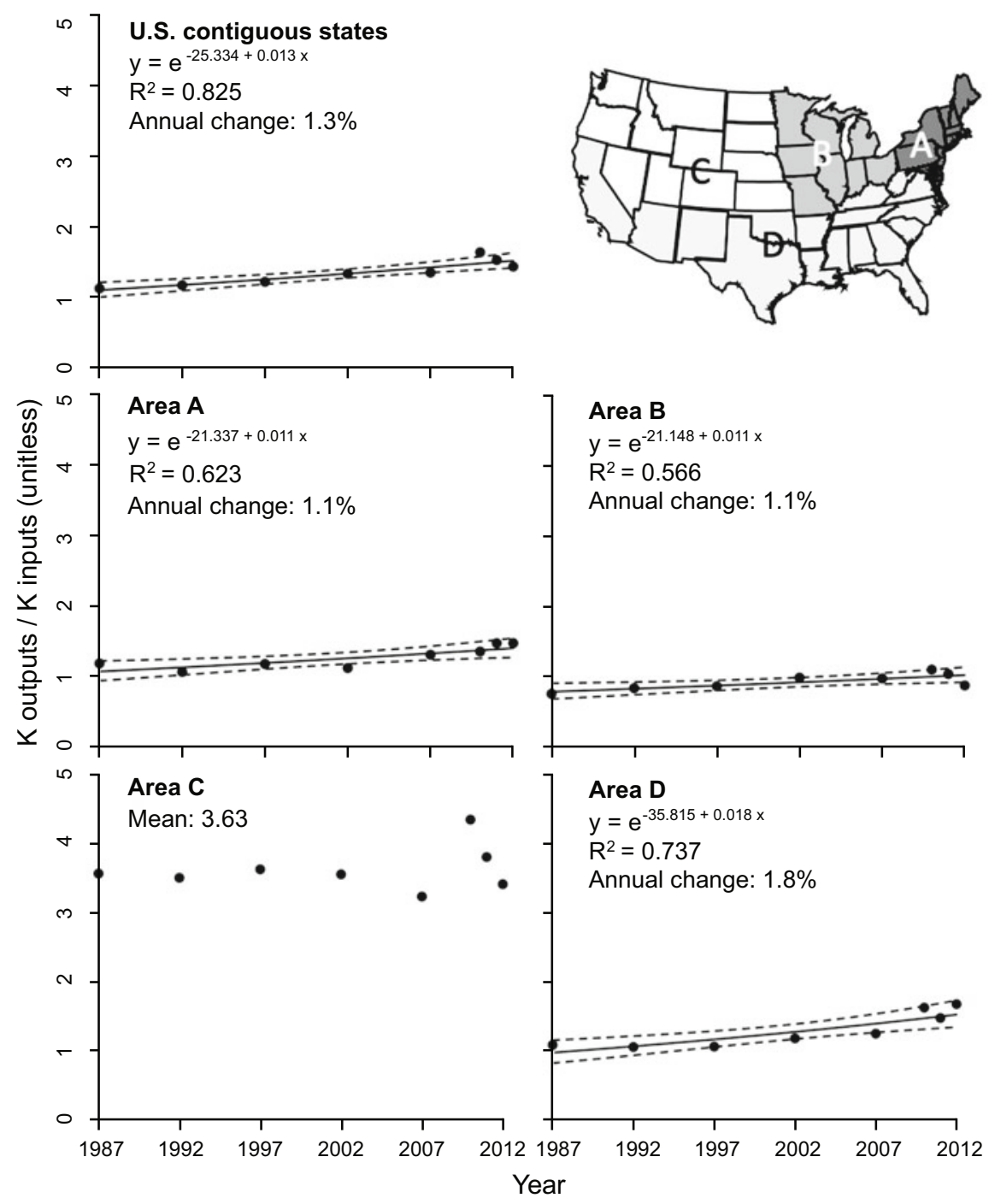

Fig. 11.9 Temporal trends in $\mathrm{K}$ removal to use ratios for the contiguous 48 states of the USA and for four groupings of U.S. states, denoted as areas A, B, C, and D. Dotted lines are the 95\% confidence intervals for the regression curves

group, $\mathrm{PNB}_{\mathrm{K}}$ levels have been increasing at a rate of $1.3 \%$ year $^{-1}$. Similar increases $\left(1.1 \%\right.$ year $^{-1}$ ) were also observed in the northeastern states (Group A) and the corn and soybean-growing states (Group B). States in Group D had the greatest increase in $\mathrm{K}$ removal to use $\left(1.8 \%\right.$ year $\left.^{-1}\right)$. Much of this area is where cotton has traditionally been grown, although cotton production has declined in recent years and is being replaced by other crops, such as soybean. In the more arid western states (Group C), 
no significant trend emerged over time. Soil K concentrations have historically been high; consequently, farmers have not applied much $\mathrm{K}$ fertilizer, resulting in a higher $\mathrm{PNB}_{\mathrm{K}}$, averaging 3.63.

The widely varied K-balance patterns across the USA arise from interactions of climate, soil properties, cropping patterns, market conditions, governmental policies, and many other factors. In general, the combination of rather steady K consumption but increased yields and therefore increased nutrient removal has led to negative $\mathrm{K}$ balances that are becoming increasingly negative in much of the USA.

\subsection{Brazil}

Since the soil nutrient status of Brazilian soils is generally low, supplying additional nutrients is generally necessary to make agriculture effective and profitable. Potassium fertilizer consumption in Brazil is high, with consumption of $5.4 \mathrm{Mt} \mathrm{K}_{2} \mathrm{O}$ in 2015 , ranking second in the world, with about $90 \%$ of it imported. A nutrient budget can represent the amount of a nutrient that is exported from the whole country, a specific location (e.g., state), or a field by a crop relative to the amount of applied nutrient.

The nutrient budgets for Brazil have been calculated for the whole country, states, and main crops based on fertilizer consumed (ANDA 2010-2015), crop production for the eighteen major crops in Brazil, namely banana, common bean (Phaseolus vulgaris L.), cassava (Manihot esculenta Crantz), castor bean (Ricinus communis L.), cocoa (Theobroma cacao L.), coffee, cotton, maize, orange, peanut, potato, rice, sorghum, soybean, sugarcane, tobacco, tomato (Solanum lycopersicum L.), and wheat (IBGE 2010-2015), and the average nutrient concentration in the harvested portion of the crops (Yamada and Lopes 1998; Cunha et al. 2010, 2011, 2014).

The data from the most recent survey (Francisco et al. 2015) for an average of 4 years (2009-2012) are summarized in Table 11.16. It is important to note that the Midwest region was responsible for $34 \%$ of the total $\mathrm{K}$ fertilizer consumption. This region provides the bulk of soybean and maize production in the country, with

Table 11.16 Average (2009-2012) annual K partial nutrient balance intensities $\left(\mathrm{PNBI}_{\mathrm{K}}\right)$ and partial nutrient balances $\left(\mathrm{PNB}_{\mathrm{K}}\right)$ for regions in Brazil

\begin{tabular}{l|l|l|l|l}
\hline \multirow{2}{*}{ Region } & Crop removal of $\mathrm{K}$ & Applied $\mathrm{K}$ & $\mathrm{PNBI}_{\mathrm{K}}$ & $\mathrm{PNB}_{\mathrm{K}}$ \\
\cline { 2 - 5 } & $\mathrm{Mt} \mathrm{K}_{2} \mathrm{O}$ & $\mathrm{Mt} \mathrm{K}_{2} \mathrm{O}$ & $\mathrm{Mt} \mathrm{K}_{2} \mathrm{O}$ & \\
\hline South & 0.91 & 0.96 & 0.05 & 0.95 \\
\hline Midwest & 1.06 & 1.29 & 0.23 & 0.82 \\
\hline Southeast & 0.66 & 1.02 & 0.35 & 0.65 \\
\hline Northeast & 0.30 & 0.43 & 0.13 & 0.70 \\
\hline North & 0.09 & 0.09 & 0.00 & 1.04 \\
\hline Brazil & 3.03 & 3.79 & 0.76 & 0.80 \\
\hline
\end{tabular}

Francisco et al. (2015) using data from ANDA 2010-2013 
Table 11.17 Average (2009-2012) annual $\mathrm{K}$ partial nutrient balance intensities $\left(\mathrm{PNBI}_{\mathrm{K}}\right)$ and partial nutrient balances $\left(\mathrm{PNB}_{\mathrm{K}}\right)$ for main crops in Brazil

\begin{tabular}{l|l|l|l|l}
\hline \multirow{2}{*}{ Crop $^{\mathrm{a}}$} & Crop removal of $\mathrm{K}$ & Applied $\mathrm{K}$ & $\mathrm{PNBI}_{\mathrm{K}}$ & $\mathrm{PNB}_{\mathrm{K}}$ \\
\cline { 2 - 5 } & $\mathrm{Mt} \mathrm{K}_{2} \mathrm{O}$ & $\mathrm{Mt} \mathrm{K}_{2} \mathrm{O}$ & $\mathrm{Mt} \mathrm{K}_{2} \mathrm{O}$ & \\
\hline Soybean & 1.64 & 1.66 & 0.02 & 0.99 \\
\hline Maize & 0.34 & 0.52 & 0.18 & 0.65 \\
\hline Sugarcane & $\mathrm{b}$ & 0.78 & 0.12 & 0.85 \\
\hline Coffee & 0.66 & 0.25 & 0.20 & 0.20 \\
\hline Cotton & 0.05 & 0.14 & 0.06 & 0.56 \\
\hline Rice & 0.08 & 0.07 & 0.01 & 0.86 \\
\hline Common bean & 0.06 & 0.05 & -0.01 & 1.20 \\
\hline Orange & 0.06 & 0.05 & 0.02 & 0.60 \\
\hline Wheat & 0.03 & 0.06 & 0.04 & 0.33 \\
\hline
\end{tabular}

Francisco et al. (2015)

${ }^{\mathrm{a} C o m m o n}$ bean (Phaseolus vulgaris L.); coffee (Coffea spp.); cotton (Gossypium hirsutum L.); maize (Zea mays L.); orange (Citrus sinensis (L.) Osbeck); rice (Oryza sativa L.); soybean (Glycine $\max$ (L.) Merr.); sugarcane (Saccharum giganteum (Walter) Pers.); wheat (Triticum aestivum L.)

${ }^{\mathrm{b}}$ For sugarcane, a $20 \%$ deduction was considered for $\mathrm{K}$ removal considering the regular disposal of vinasse

plant-available $\mathrm{K}$ being inherently low in the soil. In summary, $\mathrm{PNB}_{\mathrm{K}}$ for the whole country was 0.8 .

Nutrient budgets for nine crops grown between the years of 2009 and 2012 are presented in Table 11.17. Potassium use was higher than crop removal in most crops, with the exception of beans (1.20). Potassium use was most balanced in soybean, which had $\mathrm{PNB}_{\mathrm{K}}$ of 0.99 , followed by rice $(0.86)$ and sugarcane $(0.85)$. Coffee had the lowest $\mathrm{PNB}_{\mathrm{K}}$ value (0.20).

Soybean, maize, and sugarcane are responsible for about $70 \%$ of the $\mathrm{K}$ fertilizer consumed in Brazil. The $\mathrm{PNB}_{\mathrm{K}}$ levels for these crops are very reasonable, compared to other situations worldwide, which is indicative that Brazil has had fairly appropriate use of $\mathrm{K}$ for these crops.

In terms of states (data not shown), there is a wide range of results in terms of $\mathrm{K}$ mass balance, with some states presenting very low and others very high $\mathrm{PNB}_{\mathrm{K}}$ levels (ranging from 0.54 to 3.17 in the main agricultural states). The results from studies at specific locations with $\mathrm{K}$ mass balances allows researchers to focus on crops or regions with the most severe deficits. For example, coffee and citrus were two of the most important crops in Brazil with the lowest levels of $\mathrm{PNB}_{\mathrm{K}}$ among all crops considered in the study. Consequently, it is necessary to better study fertilizer practices and management systems that could increase NUE, leading to improved $\mathrm{PNB}_{\mathrm{K}}$ levels for both crops.

In order to extend this analysis back to represent PNB for $\mathrm{N}, \mathrm{P}$, and $\mathrm{K}$ prior to 2009, trends in mass balances of these nutrients between 1988 and 2012 are provided in Fig. 11.10. Nitrogen removal was higher than $\mathrm{N}$ input until the late 1990s. Later, $\mathrm{N}$ use in the country increased due to the adoption of more intensive cropping systems with higher inputs, especially for sugarcane, orange, coffee, and maize, 
Fig. 11.10 Partial nutrient balances (PNB) for N, P, and $\mathrm{K}$ for main crops in Brazil from 1988 to 2012

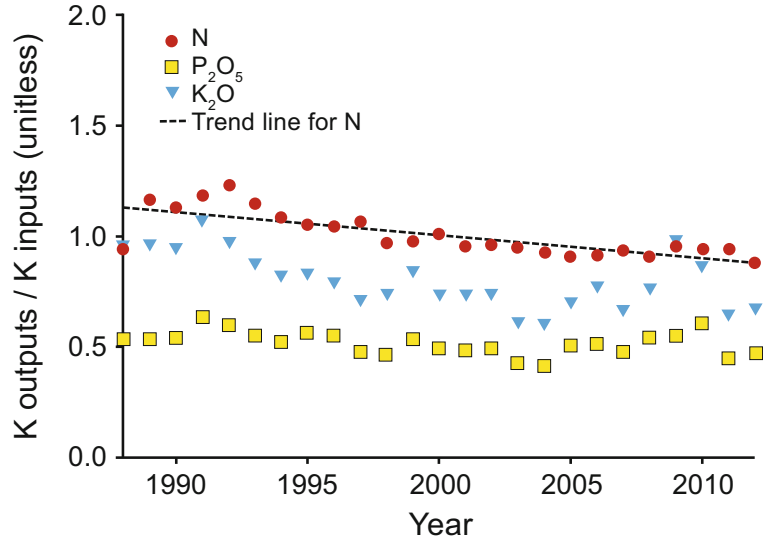

which resulted in lower N PNB $\left(\mathrm{PNB}_{\mathrm{N}}\right)$, reaching 0.87 in 2012. Phosphorus PNB $\left(\mathrm{PNB}_{\mathrm{P}}\right)$ has essentially hovered around 0.60 , which may be acceptable when compared to estimates of 0.30 in many situations. Potassium partial nutrient balances had a similar decreasing trend as $\mathrm{N}$, and $\mathrm{PNB}_{\mathrm{K}}$ reached 0.67 in 2012. Potassium showed a dramatic increase in $\mathrm{PNB}_{\mathrm{K}}$ in 2009 (0.98) that reflected a significant and temporary decrease in $\mathrm{K}$ use by farmers due to higher fertilizer prices. The generally steady growth in nutrient use in Brazil in recent years has been effective in improving crop production, increasing average yields. In 1990, the average yield was around $1.70 \mathrm{t}$ $\mathrm{ha}^{-1}$ and subsequently increased to $3.44 \mathrm{t} \mathrm{ha}^{-1} 20$ years later.

Nutrient mass balances were estimated periodically to help identify gaps in fertilizer use for specific crops or regions as well as to forecast future nutrient demands. In this context, initiatives aimed at educating farmers and agronomists on how to assess the performance of nutrient inputs are crucial for promoting fertilizer use efficiency, minimizing nutrient loss, and increasing crop production sustainability. With this in mind, a new tool was developed recently by Nutrição de Plantas Ciência e Tecnologia (NPCT) in Brazil which allows the calculation of specific nutrient mass balances at the farm level (NPCT 2020). Many agronomists around the country are using this tool to calculate nutrient mass balances for different crops and farms.

Calculation and publication of nutrient mass balances have helped agricultural stakeholders to better understand the status and efficiency in the use of different plant nutrients. For Brazil, the $\mathrm{PNB}_{\mathrm{K}}$ indicates generally appropriate ratios. Between 2009 and 2012, the average $\mathrm{PNB}_{\mathrm{K}}$ value was 0.80 , which means that overall, $80 \%$ of the fertilizer applied to crops was exported as agricultural products. The recently released web tool to calculate nutrient mass balances at the farm level is helping farmers around the country better manage fertilizers. This tool can be adapted for use in other regions. 


\subsection{Southern Cone of Latin America}

The total agricultural area of the five countries of the Southern Cone of Latin America (Argentina, Bolivia, Chile, Paraguay, and Uruguay) is 238 Mha over a total land area of 513.6 Mha. Total arable land represents approximately $22 \%$ of the agricultural area. The total area for different crop groups defined by FAOSTAT is 56.5 Mha. Field crops (oil crops, coarse grain, and cereals) lead the area and production in the region.

The main field crop areas of the Southern Cone include the Pampas and Gran Chaco regions of Argentina and Uruguay, the southern highlands of eastern Paraguay, the eastern lowlands of Bolivia, and the central valleys and southern volcanic regions of Chile.

Several soil associations are found in this region. Mollisols are dominant throughout the Pampas-Chaco plains and Uruguay and are among the best suited for agriculture because of their high native fertility. Alfisols are also widespread in the Pampas-Chaco region. Alfisols are generally fertile, with a high concentration of nutrient cations. Ultisols and Oxisols are the main soils in eastern Paraguay. These soils have good physical qualities but require high lime and phosphorus inputs. Vertisols are mainly located in the central-eastern region of Argentina, in the Entre Rios province, as well as in Uruguay. The vertisols have good nutrient concentrations, but challenging soil physical properties that demand careful management. Alluvial soils dominate the eastern lowlands of Bolivia and also have good natural soil fertility. Soils of Chile are quite variable and include Alfisols, Mollisols, Entisols, and Inceptisols in the central region, and Entisols, Inceptisols, Andisols, and Ultisols in the south. Native soil K availability is high in most of the cropping areas of the Southern Cone of Latin America (Barbazán et al. 2012; Sainz Rozas et al. 2013). Thus, fertilizer $K$ consumption in the region has been low, about $335-425 \mathrm{kt} \mathrm{K}_{2} \mathrm{O}$ in the last years (summed across the individual country consumptions shown in Fig. 11.11). However, expansion of agriculture into new areas and replacement of pastures by annual crops, mainly soybean, in the last 20 years (Wingeyer et al. 2015) have increased $\mathrm{K}$ removal by grains and induced $\mathrm{K}$ deficiencies in several regions of Uruguay (Barbazán et al. 2012, 2017), and some areas of Paraguay and Argentina.

In Argentina, the apparent consumption of $\mathrm{K}$ as fertilizers reached a peak of $54 \mathrm{kt}$ $\mathrm{K}_{2} \mathrm{O}$ (44 kt K) by 2007 (Fig. 11.11). An annual $\mathrm{PNB}_{\mathrm{K}}$ has been estimated for the four major grain crops (soybean, corn, wheat, and sunflower) considering K application and grain K removal (García and González Sanjuan 2016). This estimation used average grain $\mathrm{K}$ concentration for the four crops and assumed that crop residues were not removed from fields, a typical practice under no-tillage agriculture in Argentina.

The $\mathrm{PNB}_{\mathrm{K}}$ has been very high, with $\mathrm{K}$ removal exceeding $\mathrm{K}$ application by almost 800 times during the period 2012-2014 (Fig. 11.12). Negative K mass balances have reduced soil $\mathrm{K}$ availability $(0-20-\mathrm{cm}$ depth) to the current soil test $\mathrm{K}$ levels of $370-750 \mathrm{mg} \mathrm{K} \mathrm{kg}^{-1}$ in agricultural fields in the central Pampas (Correndo et al. 2013). This is a 32-62\% reduction from the pristine (pre-agriculture) soil test $\mathrm{K}$ 


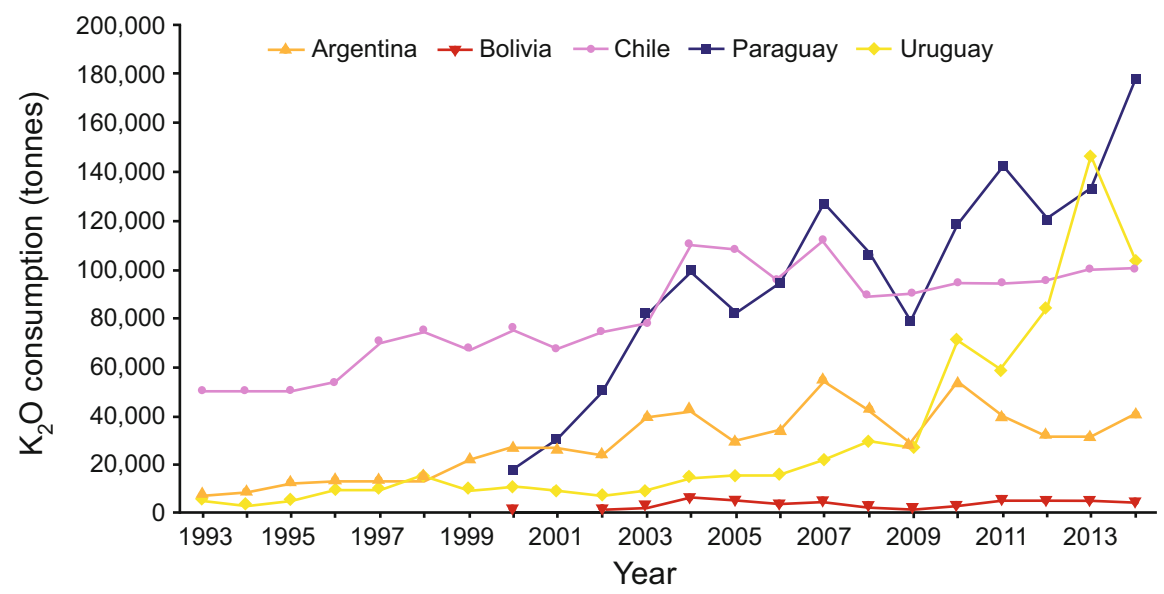

Fig. 11.11 Changes in $\mathrm{K}_{2} \mathrm{O}$ fertilizer consumption in the countries of the Latin America Southern Cone region, 1993-2014. [adapted from data of FAOSTAT, IFA, Fertilizar AC (Argentina), APIA (Bolivia), ODEPA (Chile), CAPECO (Paraguay), and MGAP-DIEA (Uruguay)]

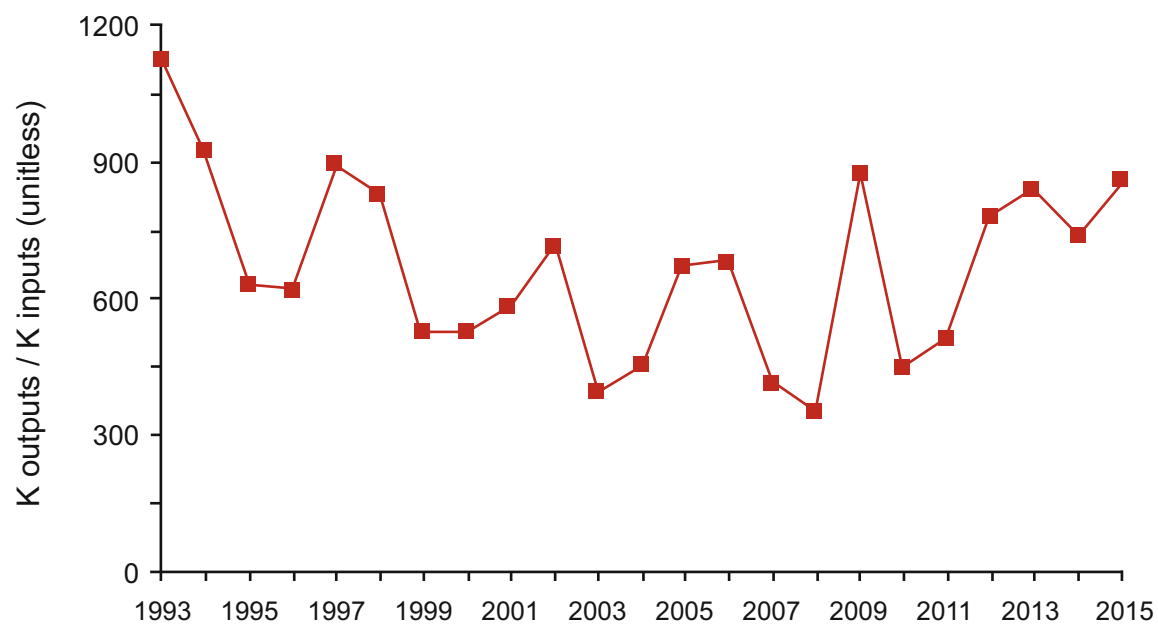

Fig. 11.12 Potassium partial nutrient balance $\left(\mathrm{PNB}_{\mathrm{K}}\right)$ estimates for the main four field crops in Argentina: soybean, maize, wheat, and sunflower. (adapted from García and González Sanjuan 2016)

concentrations of 990-1140 mg K kg${ }^{-1}$ (Fig. 11.13). Areas in northwestern Argentina under continuous sugarcane production for more than 50 years without $\mathrm{K}$ inputs have decreased soil $\mathrm{K}$ concentrations to low enough levels that crops now respond to K fertilization (Pérez Zamora 2015).

Consumption of fertilizer $\mathrm{K}$ in Bolivia is very low, with an annual average of approximately 4.4 kt during 2012-2014 (FAOSTAT 2017). Estimation of annual K 


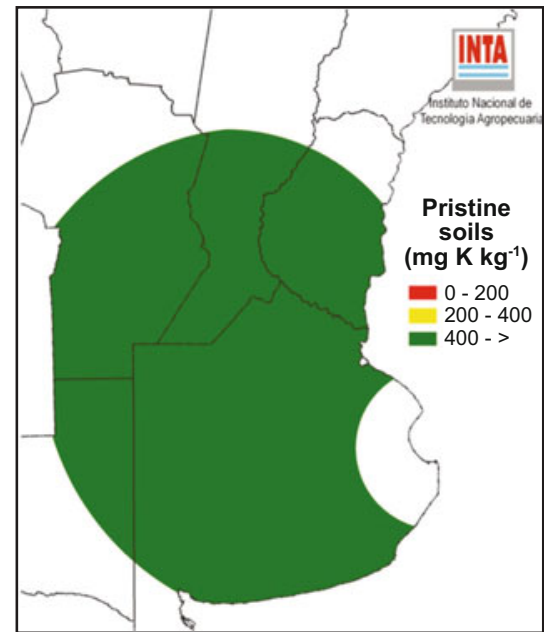

Pristine soils

Average: $756 \mathrm{mg} \mathrm{K} \mathrm{kg}^{-1}$

SD: $217 \mathrm{mg} \mathrm{K} \mathrm{kg}^{-1}$

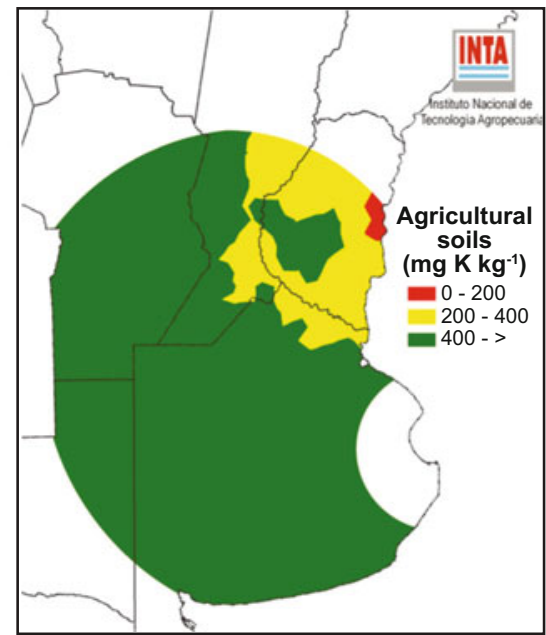

Agricultural soils

Average: $567 \mathrm{mg} \mathrm{K} \mathrm{kg}^{-1}$

SD: $173 \mathrm{mg} \mathrm{K} \mathrm{kg}^{-1}$

Fig. 11.13 Soil test K concentrations in the Pampas region of Argentina. (Sainz Rozas et al. 2013)

removal in the main harvestable products, using average $\mathrm{K}$ concentrations in crops, was $90.7 \mathrm{kt} \mathrm{K} \mathrm{year}{ }^{-1}$ for the same period, resulting in a $\mathrm{PNB}_{\mathrm{K}}>20$. Continuous removal of soil $\mathrm{K}$ without replacement will eventually result in soil fertility declines adversely affecting crop yields and farm profitability.

Mancassola and Casanova (2015) estimated a comprehensive nutrient balance for agricultural production of Uruguay. In their study, nutrient removal was estimated for: field crop production; beef, dairy, and wool production; fruit and vegetable production; and forest production. Nutrient concentrations were gathered from local information and from literature. Nutrient application was estimated from fertilizer imports. In 2010, estimated $\mathrm{PNBI}_{\mathrm{K}}$ was approximately $-24 \mathrm{kt} \mathrm{K}_{2} \mathrm{O}(-20 \mathrm{kt} \mathrm{K})$ (Fig. 11.14). These negative $\mathrm{PNBI}_{\mathrm{K}}$ levels were observed for most of the production systems because of low $\mathrm{K}$ fertilization rates, with the exception of vegetables and fruits. Furthermore, as soybean area increased in the last two decades, $\mathrm{PNBI}_{\mathrm{K}}$ in the soil has become more negative due to the high $\mathrm{K}$ requirements of soybean. Considering an average grain $\mathrm{K}$ content in $3.6 \mathrm{Mt}$ of soybean exports, it is estimated that approximately $63 \mathrm{kt} \mathrm{K}_{2} \mathrm{O}$ was removed from the soil in 2014. In addition, agriculture has also expanded to marginal soils in the north-central and eastern regions of the country, where soils with low soil test $\mathrm{K}$ levels are common (Fig. 11.15). As a result, $\mathrm{K}$ deficiencies in crops have been evident since the early 2000s (Barbazán et al. 2012, 2017).

Most of Paraguay's agricultural production takes place in the eastern half of the country on lateritic soils (mainly Oxisols and Ultisols) and includes soybean as a 


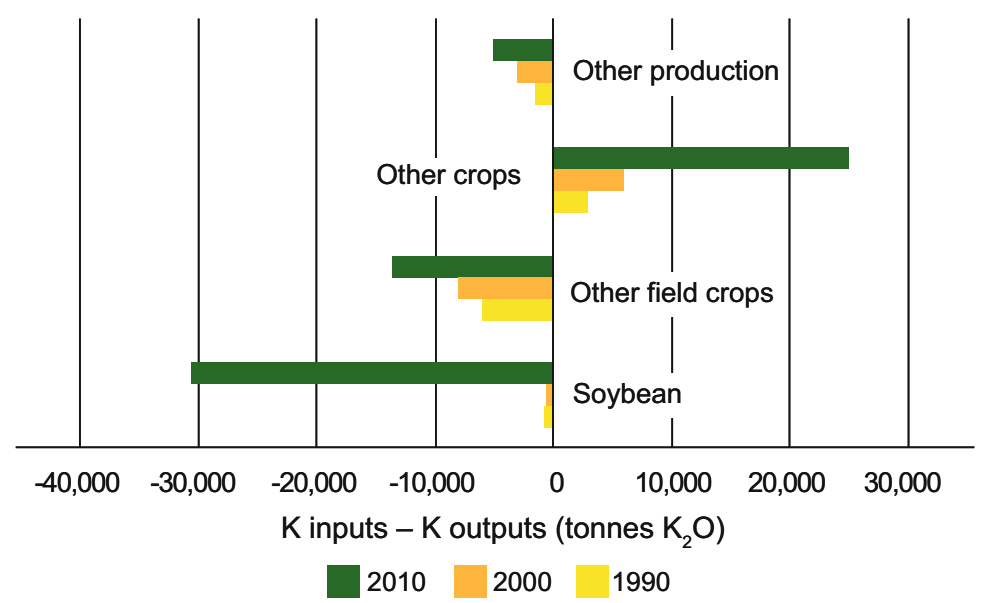

Fig. 11.14 Potassium nutrient balance intensity $\left(\mathrm{PNBI}_{\mathrm{K}}\right)$ by production system in 1990, 2000, and 2010 in Uruguay; other field crops include wheat (Triticum aestivum L.), maize (Zea mays L.), barley (Hordeum vulgare L.), sunflower (Helianthus annuus L.), sorghum (Sorghum bicolor (L.) Moench), and rice (Oryza sativa L.); other crops include fruits, citrus, and vegetables; and other production includes forestry, beef, dairy, and sheep production. (Mancassola and Casanova 2015)

main field crop, along with maize, wheat, sunflower, canola, and others. Causarano Medina (2017) estimated nutrient mass balances for the period between 1996 and 2015, considering $\mathrm{K}$ fertilizer imports and $\mathrm{K}$ removal with soybean, maize, wheat, rice, sunflower, and canola crop production. Figure 11.16 shows that $\mathrm{PNB}_{\mathrm{K}}$ in Paraguay has decreased from 3 to 4 in the period between 1996 and 2003 to a $\mathrm{PNB}_{\mathrm{K}}$ between 2 and 3 since 2003. Despite this improvement in $\mathrm{PNB}_{\mathrm{K}}$, it is still much greater than 1 , indicating that soil $\mathrm{K}$ reserves are being heavily relied upon to provide $\mathrm{K}$ for an increasingly productive agriculture. Recent surveys indicate that $58 \%$ of soil samples are above soil test $\mathrm{K}$ critical levels $\left[>0.5 \mathrm{cmol}(+) \mathrm{kg}^{-1}\right.$ or $195 \mathrm{mg} \mathrm{K} \mathrm{kg}^{-1}$ (Causarano Medina 2017).

In summary, countries of the Southern Cone of Latin America generally have $\mathrm{PNB}_{\mathrm{K}}$ levels $>1$, with correspondingly negative $\mathrm{PNBI}_{\mathrm{K}}$ values, indicating depletion of soil K. In most of the region, crop production under these negative $\mathrm{PNBI}_{\mathrm{K}}$ levels has been sustained from high levels of soil $\mathrm{K}$ reserves. However, $\mathrm{K}$ deficiencies and positive crop responses to $\mathrm{K}$ fertilization have been detected in areas such as Uruguay because of the continuous decline in the exchangeable and non-exchangeable soil $\mathrm{K}$ fractions. Site-specific evaluations of soil test $\mathrm{K}$ would provide information on the rate of decline of soil $\mathrm{K}$ supplies. Lastly, $\mathrm{K}$ application decisions based on soil test calibrations would be required to sustain high crop yields and farm profitability and to maintain soil $\mathrm{K}$ fertility. 


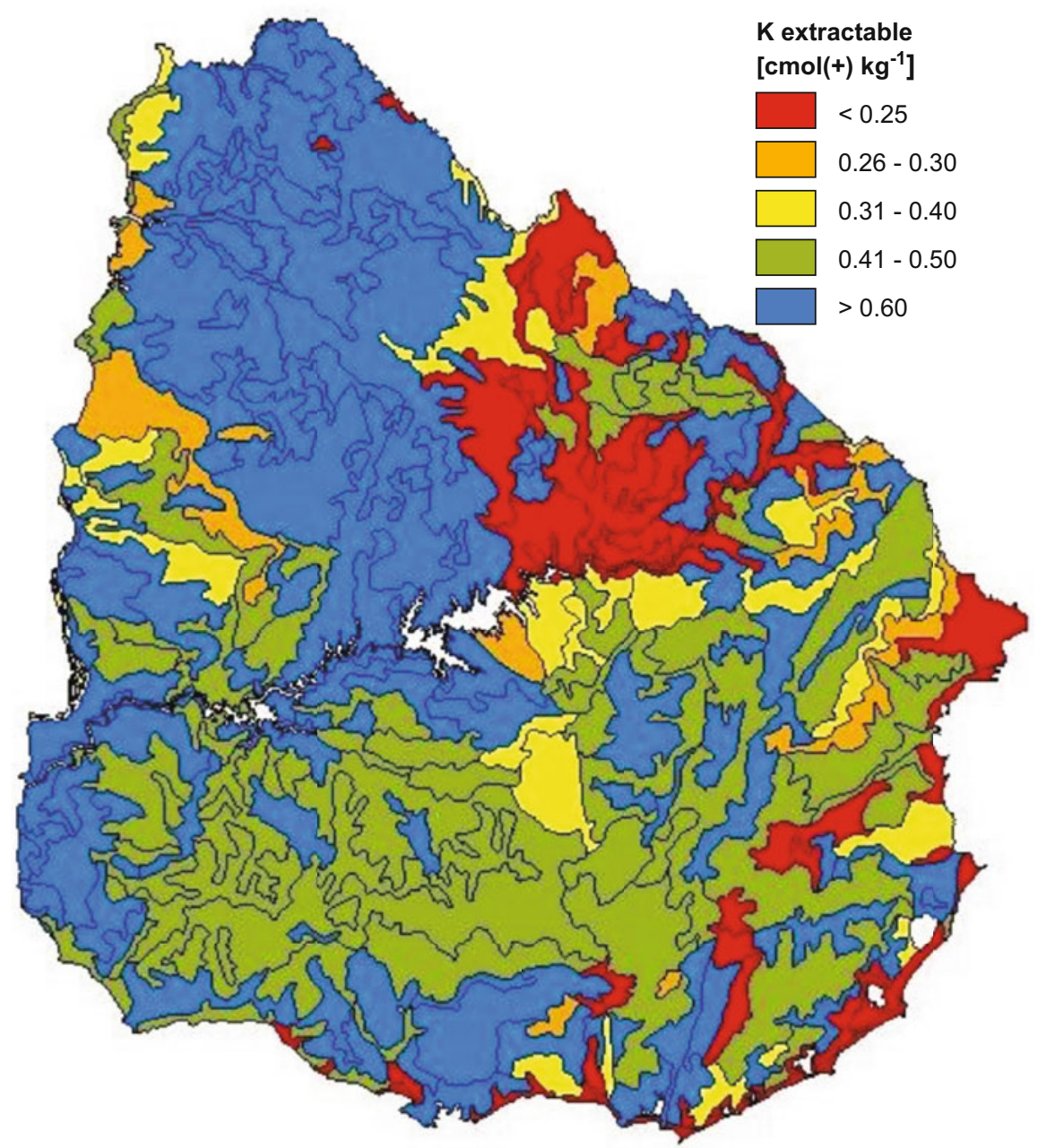

Fig. 11.15 Pristine (pre-agricultural) soil test $\mathrm{K}$ concentrations at a depth of 0 to $-20 \mathrm{~cm}$, according to the soil recognition guide of Uruguay. (Califra and Barbazan unpublished)

\subsection{Conclusion}

Estimates of $\mathrm{K}$ mass balance provide insight into soil $\mathrm{K}$ fertility trends and potential short- and long-term impacts of nutrient management practices in crop production systems. The availability of reliable data to calculate $\mathrm{K}$ mass balances differs among geographies. This is reflected in the scale, both spatial and temporal, and resolutions at which $\mathrm{K}$ balances are estimated and reported in this chapter. Table 11.18 demonstrates that the quantity of information used to estimate $\mathrm{PNB}_{\mathrm{K}}$ and $\mathrm{PNBI}_{\mathrm{K}}$ varies among assessments. Common to all, however, are estimates of $\mathrm{K}$ removed in 


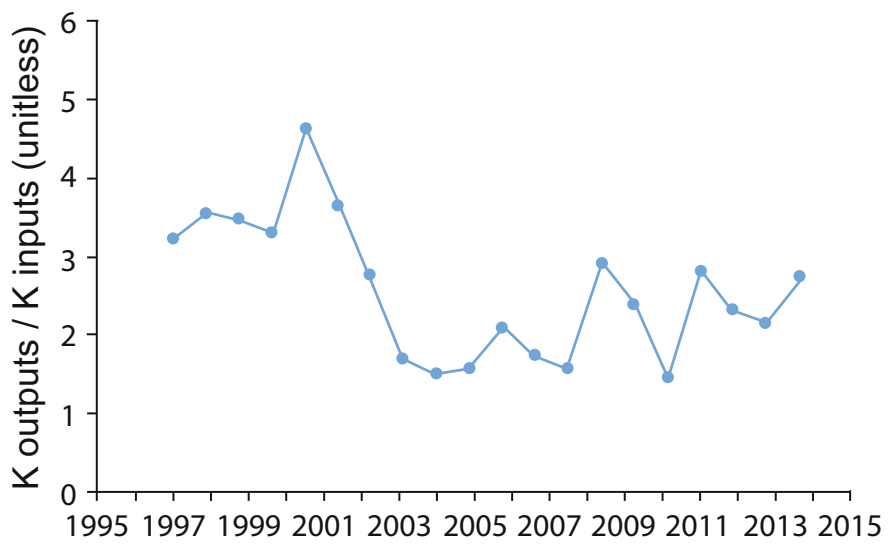

Fig. 11.16 Potassium partial nutrient balance $\left(\mathrm{PNB}_{\mathrm{K}}\right)$ estimates from 1996 to 2015 for field crop agriculture in Paraguay. (Causarano Medina 2017)

harvested agricultural products and $\mathrm{K}$ applied as inorganic fertilizer. Besides the availability and access to quality data, a large diversity of land use and methodological differences in estimating $\mathrm{K}$ mass balances are also responsible for divergent metrics reported from various parts of the world. Farmer income levels, access to information on $\mathrm{K}$ nutrition of crops, and translation of scientific knowledge to changes in nutrient management practices also play important roles on how $\mathrm{K}$ mass balances develop in a specific soil-crop context. This reinforces the concept that nutrient balances are highly contextual and must be interpreted accordingly. Nevertheless, $\mathrm{PNB}$ and $\mathrm{PNBI}_{\mathrm{K}}$ reported in this chapter, provide a useful global overview of how $\mathrm{K}$ is managed in crops, cropping systems, or in mixed enterprises. Nutrient balances are too often reported as snapshots of a year or one cropping cycle, but the trends over time are perhaps the most diagnostic of the sustainability of a given cropping system and its fertilization practices.

Temporal changes in soil $\mathrm{K}$ balance over decades at national scales are useful to provide necessary policy guidance for production, distribution and use of $\mathrm{K}$ fertilizers. China is such a case. The highly negative $\mathrm{PNBI}_{K}$ levels in soils of China in the 1980s have now changed to generally positive $\mathrm{PNBI}_{\mathrm{K}}$ levels, arising from increased awareness at the policy and user level, better access to K fertilizers, and their proper use in the field.

The spectrum of $\mathrm{PNBI}_{\mathrm{K}}$ is tilted more toward the negative side globally as more $\mathrm{K}$ is removed with each harvest than applied. Potassium applications are typically low in historically high K soils (e.g., countries in the Latin America Southern Cone, North Africa, Western USA), due to an historic lack of crop yield responses. However, crops growing in some soils in these regions are now responding to $\mathrm{K}$ fertilizer applications, and crops are more frequently showing deficiency symptoms when no $\mathrm{K}$ is applied. A combination of negative $\mathrm{PNBI}_{\mathrm{K}}$ and crop response to $\mathrm{K}$ fertilizer is an unambiguous indication of $\mathrm{K}$ fertility decline. 


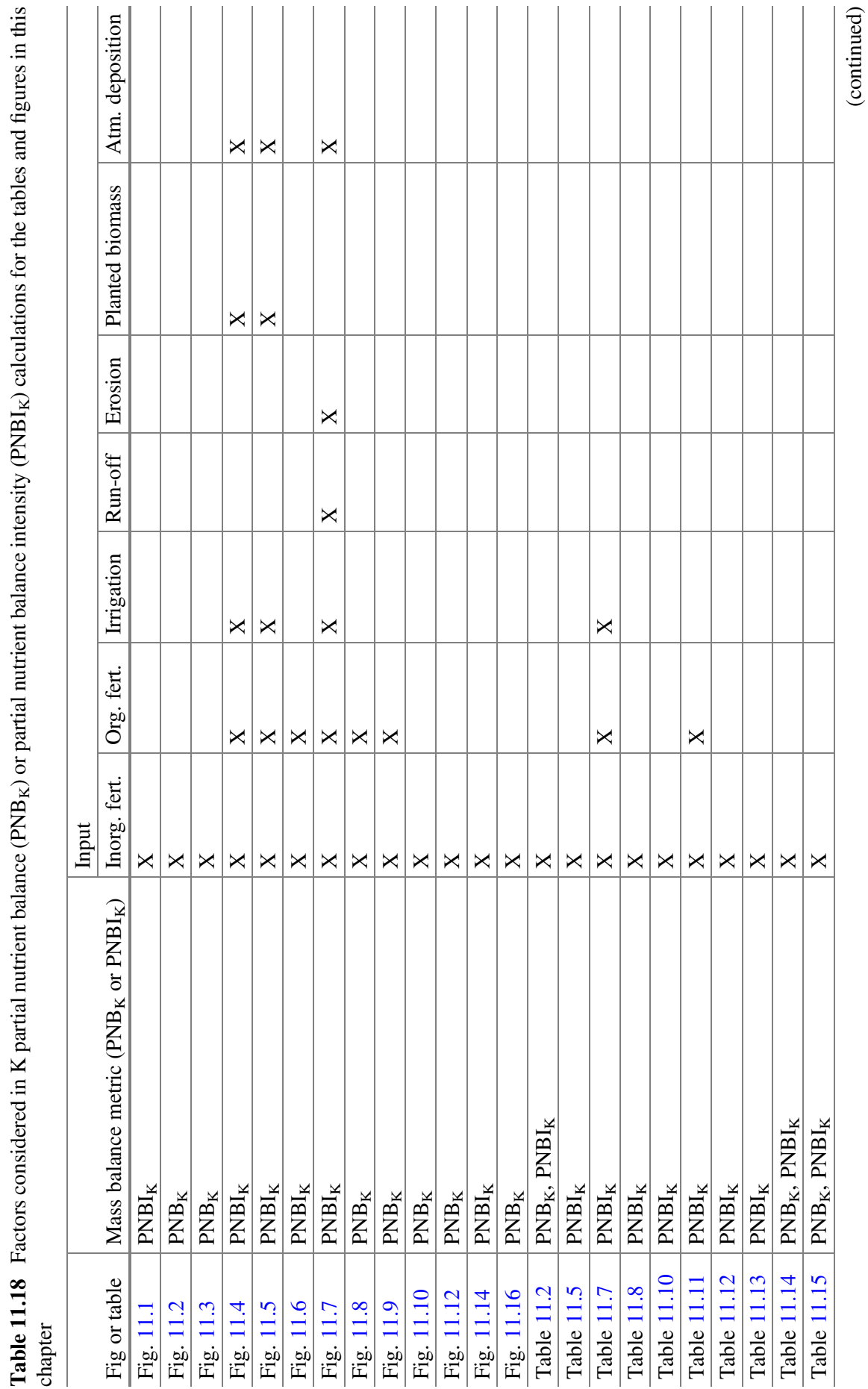



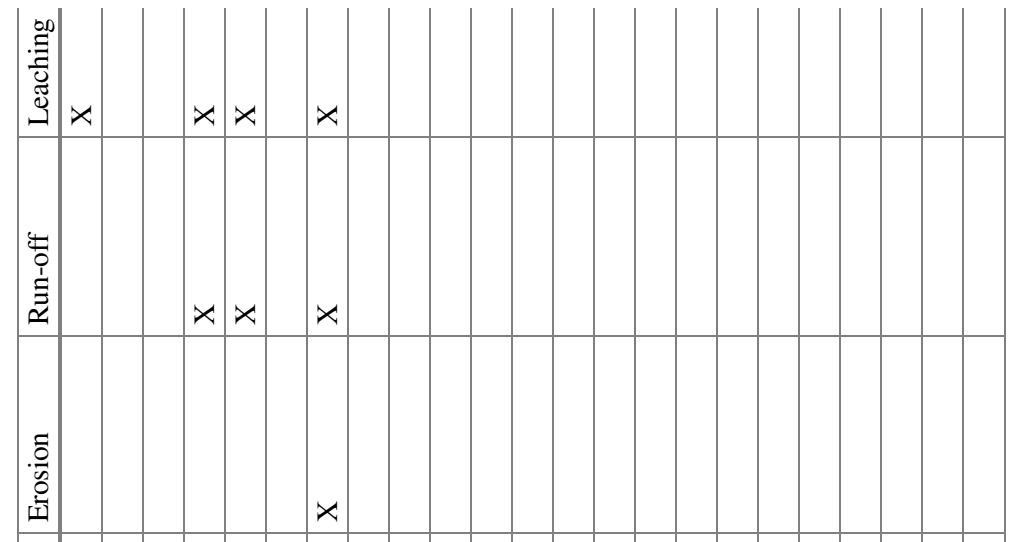

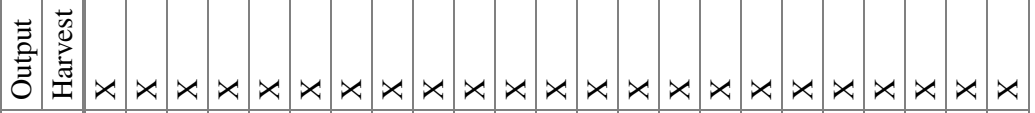

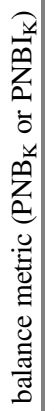

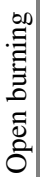

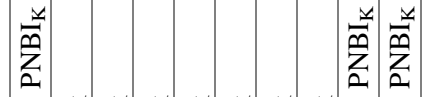

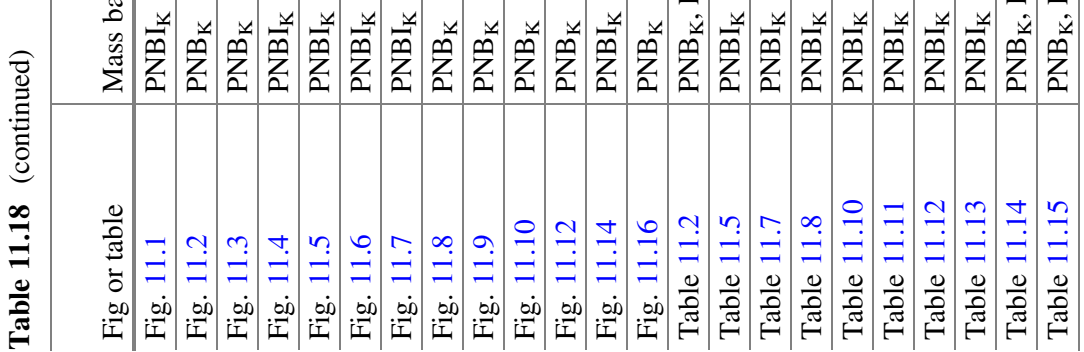


The Indian example is noteworthy in this context. The general perception is Indian soils are inherently rich in $\mathrm{K}$ and do not require further $\mathrm{K}$ fertilizer applications; however, overwhelming evidence of negative $\mathrm{PNBI}_{\mathrm{K}}$ levels at national, regional, and cropping system scales, accompanied by large crop yield losses when no $\mathrm{K}$ fertilizer is applied suggest that site-specific $\mathrm{K}$ management is necessary to maintain soil $\mathrm{K}$ fertility. Negative $\mathrm{PNBI}_{\mathrm{K}}$ levels and $\mathrm{PNB}_{\mathrm{K}}$ levels greater than unity indicate that a certain portion of crop requirements are derived from native $\mathrm{K}$ reserves. Irrespective of the soil $\mathrm{K}$ status, this process depletes soil $\mathrm{K}$. How soon the gradual $\mathrm{K}$ depletion will impede crop production is a function of the magnitude of the soil $\mathrm{K}$ reserve and the level of cropping intensity. Evidence suggests that soils with very high $\mathrm{K}$ reserves will eventually become depleted under intensive cropping when adequate $\mathrm{K}$ fertilizer is not applied (the $\mathrm{PNB}_{\mathrm{K}}$ levels are much greater than 1 ), giving credence to $\mathrm{K}$ mass balance as a reliable indicator of soil $\mathrm{K}$ mining.

Acknowledgments The Grains Research and Development Corporation supported the research into Australian farm level nutrient performance indicators reported here and the involvement of Ms Elaina vanderMark and Southern Farming Systems is acknowledged. The estimation of Australian national and regional nutrient performance indicators was done in collaboration with $\mathrm{Dr}$ Robert Edis.

\section{References}

ABARES (2016) Agricultural commodity statistics 2016, CC by 3.0. https://www.agriculture.gov. au/abares/research-topics/agricultural-commodities/agricultural-commodities-trade-data\#2019. Accessed 20 May 2020

ABS (2016) Change in collection scope for ABS rural environment and agricultural commodity collections. In: 4627.0 — Land management and farming in Australia, 2014-15. http://www.abs. gov.au/AUSSTATS/abs@.nsf/Lookup/4627.0Main+Features102014-15?OpenDocument. Accessed 20 May 2020

Achard F, Banoin M (2003) Fallows, forage and nutrient transfers by livestock in Niger. Nutr Cycl Agroecosyst 65:183-189. https://doi.org/10.1023/B:FRES.0000019453.19364.70

AICRP-IFS (2012) Annual report 2011-12. Project Directorate for Farming Systems Research (Indian Council of Agricultural Research), Modipuram, Meerut-250 110, pp 224. http://www. iifsr.res.in/AICRP/pdf/AICRP\%20on\%20IFS_Annual\%20Report_2011-12_Final.pdf.

Accessed 20 May 2020

Aissa, M, Mhiri M (2002) Détermination du seuil critique du sol en potassium pour le blé dur. Atelier sur la gestion de la fertilisation potassique, acquis et perspectives de la recherche, Tunis 10 Dec. 2002, VI:1-9. https://www.ipipotash.org/uploads/udocs/DETERMINATION\%20DU $\%$ 20SEUIL \%20CRITIQUE\%20DU\%20SOL\%20EN\%20POTASSIUM\%20POUR\%20LE\% 20BLE\%20DUR.pdf. Accessed 20 May 2020

ANDA (2010-2015) Anuário estatístico do setor de fertilizantes, São Paulo, Brazil. http://anda.org. br/statistics/. Accessed 20 May 2020

Azzaoui A, Alilou F (1990) Bilan potassique des essais de longues durées de I'INRA. Rapport annuel (1990/91) du Programme Aridoculture, INRA/MIACAID Project 0136

Azzaoui A, El Mourid M, Loudyi B, Ryan J (1993) Fertilité et fertilisation potassique au Maroc: acquis et perspectives d'avenir. Al Awamia 83:241-263. https://www.inra.org.ma/sites/default/ files/08314.pdf. Accessed 20 May 2020 
Badraoui M, Albani M, Agbani M, Bouabid R, El Gharous M, Karrou M, Zeraouli M (2002) New references for the fertilization of wheat, sugar beet and sunflower in Doukkala and Gharb irrigated perimeters in Morocco. In: Zdruli P, Steduto P, Kapur S (eds) 7th international meeting on soils with Mediterranean type of climate (selected papers), Bari (Italy), CIHEAM 2002, Option Méditerranéennes, Serie A, 50:213-218. http://om.ciheam.org/om/pdf/a50/04002035. pdf. Accessed 20 May 2020

Badraoui M, Agbani M, Bouabid R, Ait Houssa A (2003) Potassium status in soils and crops: fertilizer recommendations and present use in Morocco. In: Johnston AE (ed) Potassium and water management in west Asia and north Africa. The regional workshop of the International Potash Institute, Amman, Jordan, 5-6 November 2001, pp 161-167. https://repository. $\mathrm{r}$ o t h a m s t e d. a c. u k/d o w n l o a d /

8ba1e172ade49197d9da49b59f921ced78b0f5b3dd93d8fc47163c39c46b3f73/2813429/potas sium_and_water_management_in_west_asia_and_north_africa.pdf\#page $=151$. Accessed 20 May 2020

Barbazán M, Bautes C, Beux L, Bordoli M, Califra A, Cano JD, del Pino A, Ernst O, García A, García F, Mazzilli S, Quincke A (2012) Soil potassium in Uruguay: current situation and future prospects. Better Crops 96(4):21-23. http://www.ipni.net/publication/bettercrops.nsf/0/ 1FFDD7D98D161AA906257ABB005B785A/\$FILE/BC\%202012-4\%20p.\%2021.pdf. Accessed 20 May 2020

Barbazán M et al (2017) Assessment of potassium deficiencies in agricultural systems in Uruguay. In: International Plant Nutrition Institute (ed) Abstracts of the frontiers of potassium science conference, Rome, Italy, January 2017. https://www.apni.net/k-frontiers/. Accessed May 292020

Bell MJ, Moody P (2005) Chemical fertility and soil health in northern systems. https://grdc.com. au/Media-Centre/Ground-Cover/Ground-Cover-Issue-56/Chemical-fertility-and-soil-health-innorthern-systems. Accessed 20 May 2020

Belouchrani AS, Daoud Y, Derdour H (2002) Study of potassium in Mediterranean red soils of Algeria by biological method. In: Rubio JL, Morgan RPC, Asins S, Andreu A (eds) Proceeding of the 3rd international congress: man and soil at the third millennium. Geoforma ediciones, Logroño, pp 1065-1069

Bijay-Singh, Yadviner-Singh, Imas P, Xie JC (2003) Potassium nutrition of the rice-wheat cropping system. Adv Agron 81:203-259. https://doi.org/10.1016/S0065-2113(03)81005-2

Biswas PP, Sharma PD (2008) A new approach for estimating fertiliser response ratio-the Indian scenario. Indian J Fert 4(7):59-62

Brennan RF, Bell MJ (2013) Soil potassium-crop response calibration relationships and criteria for field crops grown in Australia. Crop Pasture Sci 64(5):514-522. https://doi.org/10.1071/ CP13006

Buresh RJ, Pampolino MF, Witt C (2010) Field-specific potassium and phosphorus balances and fertilizer requirements for irrigated rice-based cropping systems. Plant Soil 335:35-64. https:// doi.org/10.1007/s11104-010-0441-z

Causarano Medina HJ (2017) Fertilización y balance de nutrientes en la agricultura mecanizada paraguaya. In: Benítez León G et al (eds) IV Congreso Nacional de Ciencias Agrarias. San Lorenzo, Paraguay, 19-21 April 2017, pp 32-35. http://www.agr.una.py/fca/index.php/libros/ catalog/book/303. Accessed 20 May 2020

Chand R (2007) Demand for food grains. Econ Polit Wkly 42(52):10-13. https://www.epw.in/ journal/2007/52/commentary/demand-foodgrains.html. Accessed 20 May 2020

Chatterjee S, Santra P, Majumdar K, Ghosh D, Das I, Sanyal SK (2015) Geostatistical approach for management of soil nutrients with special emphasis on different forms of potassium considering their spatial variation in intensive cropping system of West Bengal, India. Environ Monit Assess 187:183. https://doi.org/10.1007/s10661-015-4414-9

Christy B, Clough A, Riffkin P, Norton R, Midwood J, O’Leary G, Stott K, Weeks A, Potter T (2015) Managing crop inputs in a high yield potential environment-HRZ of southern 
Australia. State of Victoria Department of Economic Development, Jobs, Transport and Resources. Melbourne. https://doi.org/10.13140/RG.2.1.3224.6884

Chuan LM, Zheng HG, Tan CP, Sun SF, Zhang JF (2014) Characteristics of K nutrient input/output and its balance for wheat season in China. Appl Mech Mater 678:720-725. https://doi.org/10. 4028/www.scientific.net/AMM.678.720

Corley RHV, Tinker PB (2016) The products of the oil palm and their extraction. In: Corley R, Tinker P (eds) The oil palm. Blackwell, London, pp 445-466. https://doi.org/10.1002/ 9780470750971.ch13

Correndo A, Ciampitti IA, Rubio G et al (2013) Soil-test potassium dynamics in Mollisols as affected by crop management. In: XVII international plant nutrition colloquium, Istanbul, Turkey

Cunha JF, Casarin V, Prochnow LI (2010) Nutrient budget in Brazilian agriculture in 2008. Informações Agronômicas 130:1-11 (In Portuguese). https://www.npct.com.br/publication/iabrasil.nsf/CB94A790AA6AB82683257A90000C0822/\$File/Page1-11-130.pdf. Accessed 20 May 2020

Cunha JF, Casarin V, Prochnow LI (2011) Nutrient budget in Brazilian agriculture: 1988 to 2010. Informações Agronômicas 135:1-7 (In Portuguese). https://www.npct.com.br/publication/iabrasil.nsf/9CA193D11CE9775583257A8F005D3F2C/\$File/Page1-7-135.pdf. Accessed 20 May 2020

Cunha JF, Francisco EAB, Casarin V, Prochnow LI (2014) Nutrient budget in Brazilian agriculture: 2009 to 2012. Informações Agronômcias 145:1-13 (In Portuguese). https://www.npct.com.br/ publication/ia-brasil.nsf/0FAA336F68608D3983257CB30071DE8C/\$File/Page1-13-145.pdf. Accessed 20 May 2020

DAC (2011) Agriculture Census Division, Department of Agriculture and Cooperation, Ministry of Agriculture, Government of India. http://inputsurvey.dacnet.nic.in/districttables.aspx. Accessed 20 May 2020

Deckers J (2002) A systems approach to target balanced nutrient management in soilscapes of Sub-Saharan Africa. In: Vanlauwe B, Diels J, Sanginga N, Merckx R (eds) Integrated plant nutrient management in sub-Saharan Africa: from concept to practice. CAB, Wallingford, pp 47-61. https://books.google.ca/books?id=0oP_0c-MjNEC. Accessed 20 May 2020

Dierolf T, Fairhurst T, Mutert E (2001) Soil fertility kit: a toolkit for acid, upland soil fertility management in Southeast Asia. Deutsche Gesellschaft für Technische Zusammenarbeit (GTZ) GmbH; Food and Agriculture Organization; PT Jasa Katom; and Potash \& Phosphate Institute (PPI), Potash \& Phosphate Institute of Canada (PPIC)

Dobermann, A (2007) Nutrient use efficiency-measurement and management. In: IFA international workshop on fertilizer best management practices. Brussels, Belgium, pp 1-28

Dobermann A, Santa Cruz PC, Cassman KG (1996) Fertilizer inputs, nutrient balance, and soil nutrient supplying power in intensive, irrigated rice systems. I. Potassium uptake and $\mathrm{K}$ balance. Nutr Cycl Agroecosyst 46(1):1-10. https://doi.org/10.1007/BF00210219

Donough CR, Cahyo A, Oberthür T, Wandri R, Gerendas J, Rahim GA (2014) Improving nutrient management of oil palms on sandy soils in Kalimantan using the 4R concept of IPNI. Paper presented at the 5 th international oil palm conference on the green palm oil for food security and renewable energy, Bali, Indonesia, 17-19 June 2014. http://seap.ipni.net/ipniweb/region/seap. nsf/0/ACD99CDC8F27744A48257D2B0027D3C9/\$FILE/05\%20OP\%20Nutrient\%20Mgt\% 20on\%20Sandy\%20Soils.pdf. Accessed 20 May 2020

Drew N. (2018) Fertilizer Australia. Personal Communication

Dutta S, Majumdar K, Khurana HS, Sulewski G, Govil V, Satyanarayana T, Johnston A (2013) Mapping potassium budgets across different states of India. Better Crops South Asia 7 ( 1 ) : $28-31$. h t t p : / / s a p.ipni.net/i p niweb/region/sap.ns f/ $0 /$ 74A459D53F41349E85257C44003364A9/\$FILE/Mapping\%20Potassium\%20Budgets\% 20Across\%20Different\%20States\%20of\%20India_2013.pdf. Accessed 20 May 2020

Edis R, Norton RM, Dassanayake K (2012) Soil nutrient budgets of Australian natural resource management regions. In: Burkitt LL, Sparrow LA (eds) Proceedings of the 5th joint Australian 
and New Zealand soil science conference: soil solutions for diverse landscapes. Australian Society of Soil Science, Hobart, p 11

El Oumri M (1985) Etude pédologique au 1/50.000ème des sols de Abda.Projet intégré de Abda. Dpt. du Milieu Physique. Rabat, INRA, Maro

Elias E, Morse S, Belshaw DRG (1998) Nitrogen and phosphorus balances in Kindo Kiosha farms in southern Ethiopia. Agric Ecosyst Environ 71:93-113. https://doi.org/10.1016/s0167-8809 (98)00134-0

EU Nitrogen Expert Panel. (2015) Nitrogen Use Efficiency (NUE) - an indicatro of the utilization of nitrogen in agriculture and food system. Available from: http://www.eunep.com/wp-content/ uploads/2017/03/Report-NUE-Indicator-Nitrogen-Expert-Panel-18-12-2015.pdf [04 October 2020]

FAI (2007) Fertiliser statistics 2007. The Fertiliser Association of India, New Delhi, India. https:// www.faidelhi.org/statistics/statistical-database. Accessed 20 May 2020

FAI (2008) Fertiliser Statistics 2008. The Fertiliser Association of India, New Delhi, India. https:// www.faidelhi.org/statistics/statistical-database. Accessed 20 May 2020

FAI (2011) Fertiliser Statistics 2011. The Fertiliser Association of India, New Delhi, India. https:// www.faidelhi.org/statistics/statistical-database. Accessed 20 May 2020

FAI (2016) Fertiliser Statistics 2016. The Fertiliser Association of India, New Delhi, India. https:// www.faidelhi.org/statistics/statistical-database. Accessed 20 May 2020

FAOSTAT (2017) Food and Agriculture Organization of the United Nations. http://faostat.fao.org. Accessed 20 May 2020

FAOSTAT (2018) Food and Agriculture Organization of the United Nations. http://faostat.fao.org. Accessed 20 May 2020

Fixen P, Brentrup F, Bruulsema T, Garcia F, Norton R, Zingore S (2015) Nutrient/fertilizer use efficiency: measurement, current situation and trends. In: Drechsel P, Heffer P, Magen H, Mikkelsen R, Wichelns D (eds) Managing water and fertilizer for sustainable agricultural intensification. International Fertilizer Industry Association (IFA), International Water Management Institute (IWMI), International Plant Nutrition Institute (IPNI), and International Potash Institute (IPI). Paris, France. pp 8-37. http://www.iwmi.cgiar.org/Publications/Books/PDF/man aging_water_and_fertilizer_for_sustainable_agricultural_intensification.pdf. Accessed 20 May 2020

Fixen P, Williams R, Rund Q. (2012) Nugis: a nutrient use information system (NuGIS) for the U. S. http://www.ipni.net/ipniweb/portal.nsf/0/5D3B7DFAFC8C276885257743. Accessed 04 Oct 2020

Francisco EAB, Cunha JF, Prochnow LI, Cassarin V (2015) A look at the nutrient budget for Brazilian agriculture. Better Crops 99:4-6. http://www.ipni.net/publication/bettercrops.nsf/0/ 4AA9B3E5A82C5C5F85257E4C0062CB6D/\$FILE/BC-2015-2.pdf. Accessed 20 May 2020

Gami SK, Ladha JK, Pathak H, Shah M, Pasuquin E, Pandey S, Hobbs P, Joshy D, Mishra R (2001) Long-term changes in yield and soil fertility in a twenty-year rice-wheat experiment in Nepal. Bio Fert Soils 34:73-78. https://doi.org/10.1007/s003740100377

García FO, González Sanjuan MF (2016) Consumo de fertilizantes en el mundo y en la Argentina. In: Lavado, R (ed) Sustentabilidad de los agrosistemas y uso de fertilizantes. Orientacion Grafica Editora, Buenos Aires, Argentina. http://lacs.ipni.net/ipniweb/region/lacs.nsf/ e0f085ed5f091b1b852579000057902e/251e0b2ce526f8b1032580360060025a/\$FILE/Garcia $\% 20 \mathrm{y} \% 20$ Gonzalez $\% 20$ Sanjuan $\% 20-\% 20$ Consumo $\% 20 \mathrm{de} \% 20$ fertilizantes $\% 20 \mathrm{en} \% 20 \mathrm{el} \%$ 20mundo\%20y\%20en\%20la\%20Argentina.pdf. Accessed 20 May 2020

Ghanem H, Amnai L, Azzaoui M, Bouksirat H, El Gharous M, Oubahammou S (1983) Nitrogen, phosphate, potassium and management of arid and semi-arid soils of Morocco (preliminary results of a large-scale research project). In: Nutrient balance and the need of fertilizers in semiarid and arid regions. In: Proceedings of the 17th colloquium of the International Potash Institute, Rabat and Marrakech, Morocco, pp 259-278. https://www.ipipotash.org/uploads/ udocs/nutrient_balances_and_the_need_for_fertilizers_in_semi-arid_and_arid_regions.pdf. Accessed 20 May 2020 
Giller KE, Rowe EC, de Ridder N, van Keulen H (2006) Resource use dynamics and interactions in the tropics: scaling up in space and time. Agric Syst 88(1):8-27. https://doi.org/10.1016/j.agsy. 2005.06.016

GOI (2020) Web based land use statistics information system, Agriculture Information Division, Ministry of Communication \& IT, Govt. of India, New Delhi. https://aps.dac.gov.in/LUS/Index. htm. Accessed 20 May 2020

Gourley CJP, Dougherty WJ, Weaver DM, Aarons SR, Awty IM, Gibson DM, Hannah MC, Smith AP, Peverill KI (2012) Farm-scale nitrogen, phosphorus, potassium and sulfur balances and use efficiencies on Australian dairy farms. Anim Prod Sci 52:929-944. https://doi.org/10.1071/ AN11337

Halilat MT (2004) Effect of potash and nitrogen fertilization on wheat under Saharan conditions. Paper presented at the International Potash Institute regional workshop on potassium and fertigation development in west Asia and north Africa, Rabat, Morocco, 24-28 November 2004. https://www.ipipotash.org/uploads/udocs/Effect\%20of\%20Potash\%20and\%20Nitrogen $\% 20$ Fertilization $\% 20$ on\%20Wheat\%20under\%20Saharan\%20Conditions.pdf. Accessed 20 May 2020

Hamza A, Bamouh A, El Guilli M, Bouabid R (2012) Response of clementine citrus var. Cadoux to foliar potassium fertilization; Effects on fruit production and quality. Int Potash Insti ifc 31:14-28. https://www.ipipotash.org/publications/eifc-241. Accessed 20 May 2020

He P, Li ST, Jin JY, Wang HT, Li CJ, Wang YL, Cui RZ (2009) Performance of an optimized nutrient management system for double-cropped wheat-maize rotations in north-central China. Agron J 101(6):1489-1496. https://doi.org/10.2134/agronj2009.0099

He P, Yang LP, Xu XP, Zhao SC, Chen F, Li ST, Tu SH, Jin JY, Johnston AM (2015) Temporal and spatial variation of soil available potassium in China (1990-2012). Field Crop Res 173:49-56. https://doi.org/10.1016/j.fcr.2015.01.003

Heffer P (2013) Assessment of fertilizer use by crop at the global level: 2010-2010/11. International Fertilizer Industry Association. Paris, France. https://www.fertilizer.org/images/Library_Down loads/AgCom.13.39\%20-\%20FUBC\%20assessment\%202010.pdf. Accessed 20 May 2020

Henao J, Baanante C (2006) Agricultural production and soil nutrient mining in Africa: implications for resource conservation and policy development. IFDC International Center for Soil Fertility and Agricultural Development, Muscle Shoals. https://allafrica.com/download/resource/main/ main/idatcs/00010778:649998c684810e9ebb44cc5c59e24454.pdf. Accessed 20 May 2020

Huang SW, Jin JY, Bai YL, Yang LP (2007) Evaluation of nutrient balance in soil-vegetable system using nutrient permissible surplus or deficit rate. Commun Soil Sci Plan 38 (7-8):959-974. https://doi.org/10.1080/00103620701277973

IBGE (Instituto Brasileiro de Geografia e Estatística) (2010-2015). n.23-26. https://www.ibge.gov. br/estatisticas/economicas/agricultura-e-pecuaria.html. Accessed 20 May 2020

IFA (2020) Regional nutrient use efficiency trends and sustainable fertilizer management, synthesis papers. https://www.ifastat.org/nutrientuse- efficiency. Accessed 04 Oct 2020

Kuznets S (1955) Economic growth and income inequality. Am Econ Rev 45:1-28. www.jstor.org/ stable/1811581. Accessed 20 May 2020

Ladha JK, Dawe D, Pathak H, Padre AT, Yadav RL, Singh B, Singh Y, Singh Y, Singh P, Kundu AL, Sakal R, Ram N, Regmi AP, Gami SK, Bhandari AL, Amin R, Yadav CR, Bhattarai EM, Das S, Aggarwal HP, Gupta RK, Hobbs PR (2003) How extensive are yield declines in longterm rice wheat experiments in Asia? Field Crop Res 81:159-180. https://doi.org/10.1016/S03784290(02)00219-8

Laoubi K, Yamao M (2012) The challenge of agriculture in Algeria: are policies effective? Agric Fish Econ Res 12:65-73. http://home.hiroshima-u.ac.jp/food0709/seika/seika2012-3.pdf. Accessed 20 May 2020

Lassaletta L, Billen G, Grizzetti B, Anglade J, Garnier J (2014) 50 year trends in nitrogen use efficiency of world cropping systems: the relationship between yield and nitrogen input to cropland. Environ Res Lett 9(10):105011. https://doi.org/10.1088/1748-9326/9/10/105011 
Li S, Duan Y, Guo T, Zhang P, He P, Johnson A, Scherbakov A (2015) Potassium management in potato production in Northwest region of China. Field Crop Res 174:48-54. https://doi.org/10. 1016/j.fcr.2015.01.010

Lin B (1989) Application of chemical fertilizers in China. Beijing Science and Technology Press, Beijing

Liu RL, Jin JY, Wu RG et al (2000) Potassium balance in soil crop system and effectiveness of potash fertilizer in north China. II: yield responses on main crops to potash fertilizer application. Soil Fertil Sci China 1:9-11. (In Chinese)

Liu YX, Ma JC, Ding WC, He WT, Lei QL, Gao Q, He P (2017a) Temporal and spatial variation of potassium balance in agricultural land at national and regional levels in China. PloS One 12(9): e0184156. https://doi.org/10.1371/journal.pone.0184156

Liu YX, Yang JY, He WT, Ma JC, Gao Q, Lei QL, He P, Wu HY, Ullah S, Yang FQ (2017b) Provincial potassium balance of farmland in China between 1980 and 2010. Nutr Cycl Agroecosyst 107(2):247-264. https://doi.org/10.1007/s10705-017-9833-2

Majumdar K, Kumar A, Shahi V, Satyanarayana T, Jat ML, Kumar D, Pampolino M, Gupta N, Singh V, Dwivedi BS, Meena MC, Singh VK, Kamboj BR, Sidhu HS, Johnston A (2012) Economics of potassium fertiliser application in rice, wheat and maize grown in the IndoGangetic Plains. Indian J Fert 8(5):44-53. https://repository.cimmyt.org/handle/10883/1573. Accessed 20 May 2020

Majumdar K, Sanyal SK, Dutta SK, Satyanarayana T, Singh VK (2016) Nutrient mining: addressing the challenges to soil resources and food security. In: Singh U, Praharaj C, Singh S, Singh N (eds) Biofortification of food crops, Springer, New Delhi, India, pp 177-198, ISBN: 978-81-322-2714-4. https://doi.org/10.1007/978-81-322-2716-8_14

Mancassola V, Casanova O (2015) Balance de nutrientes de los principales productos agropecuarios de Uruguay para los años 1990, 2000 y 2010. Informaciones Agronomicas de Hispanoamerica 17:2-13

Mazid Miah MA, Saha PK, Islam A, Nazmul Hasan M, Nosov V (2008) Potassium fertilization in rice-rice and rice-wheat cropping system in Bangladesh. Bangladesh J Agric Environ 4:51-67

McLaughlin M, Fillery IR, Till AR (1992) Operation of the phosphorus, sulphur and nitrogen cycles. In: Gifford RM, Barson MM (eds) Australia's renewable resources: sustainability and global change. Bureau of Rural Resources and CSIRO Division of Plant Industry, Canberra, pp 67-110. http://hdl.handle.net/102.100.100/248737?index=1. Accessed 20 May 2020

Mhiri A (2002) Le potassium dans les sols de Tunisie. In: Atelier sur la gestion de la fertilisation potassique: acquis et perspectives de la recherche, II.1-II.13. https://www.ipipotash.org/ uploads/udocs/LE\%20POTASSIUM\%20DANS\%20LES\%20SOLS\%20DE\%20TUNISIE.pdf. Accessed 20 May 2020

Mugwira LM, Murwira HK (1998) A review of manure as a soil fertility amendment in Zimbabwe: some perspectives. In: Waddington SR, Murwira HK, Kumwenda JDT, Hikwa D, Tagwira F (eds) Soil fertility research for maize-based farming systems in Malawi and Zimbabwe, Proceedings of the soil fertility network results and planning workshop, Mutare, Zimbabwe 7-11 July 1997. Soil FertNet and CIMMYT-Zimbabwe, Harare, pp 195-201 https://reposi tory.cimmyt.org/bitstream/handle/10883/539/66144.pdf?sequence $=1 \&$ isAllowed $=$ y.

Accessed 20 May 2020

NAAS (2006) Low and declining crop response to fertilizers. Policy paper no. 35, National Academy of Agricultural Sciences (NAAS), New Delhi, p 8. http://naasindia.org/Policy\% 20Papers/policy\%2035.pdf. Accessed 20 May 2020

Naidu LGK, Ramamurthy V, Sidhu GS, Sarkar D (2011) Emerging deficiency of potassium in soils and crops of India. Karnataka J Agric Sci 24:12-19

NAL (2020) Soil nutrient balance. National Agricultural Library (NAL) thesaurus and glossary. https://agclass.nal.usda.gov/glossary.shtml. Accessed 20 May 2020

National Land and Water Resources Audit 2001. Nutrient balance in regional farming systems and soil nutrient status. National Land and Water Resources Audit, Final Report, September 2001. National Heritage Trust, Australia 
Niu JF, Zhang WF, Chen XP, Li CJ, Zhang FS, Jiang LH, Liu ZH, Xiao K, Assaraf M, Imas P (2013) Potassium fertilization on maize under different production practices in the North China Plain. Agron J 103(3):822-829. https://doi.org/10.2134/agronj2010.0471

Nkonya E, Kaizzi C, Pender J (2005) Determinants of nutrient balances in a maize farming system in eastern Uganda. Agric Syst 85(2):155-182. https://doi.org/10.1016/j.agsy.2004.04.004

NLWA (2001) Nutrient balance in regional farming systems and soil nutrient status. National Heritage Trust, Canberra. p 89. http://lwa.gov.au/programs/national-land-and-water-resourcesaudit. Accessed 20 May 2020

Norton RM (2012) Wheat grain nutrient concentrations for south-eastern Australia. In: Yunusa I (ed) Capturing opportunities and overcoming obstacles in Australian agronomy. In: Proceedings of the 16th Australian agronomy conference, Armidale, NSW 14-18 Oct 2012

Norton RM (2014a) Canola seed nutrient concentrations for southern Australia. In: Ware AH, Potter TD (eds) Proceedings of the 18th Australian research assembly on brassicas (ARAB 18). Tanunda, Australia, 29 September - 2 October, 2014. Australian Oilseed Federation, pp 1-6. http://anz.ipni.net/ipniweb/region/anz.nsf/0/0C598E0085BBA369CA257D69000B5FD9/ \$FILE/Norton\%20ARAB\%20Canola\%20Paper.pdf. Accessed 20 May 2020

Norton RM (2014b) Do we need to revisit potassium? In: Proceedings of the grains research and development corporation advisor updates, Adelaide, Australia, 25-26 February 2014, pp 199-204. https://grdc.com.au/resources-and-publications/grdc-update-papers/tab-content/grdcupdate-papers/2014/02/do-we-need-to-revisit-potassium. Accessed 20 May 2020

Norton RM (2017) Potassium removal and use in Australia. Murrell TS, Mikkelsen RL (eds) Frontiers of potassium science, Rome, Italy, 25-27 Jan 2017. International Plant Nutrition Institute, Peachtree Corners, GA, pp 33-44. https://www.apni.net/k-frontiers/. Accessed May 292020

Norton RM, Davidson E, Roberts TL (2015) Nitrogen use efficiency and nutrient performance indicators. GPNM task team report and recommendations, position paper from the GPNM's task team workshop, Washington, DC, 8 Dec 2014. http://wedocs.unep.org/bitstream/handle/20.500. 11822/10750/Nutrient_use.pdf?sequence=1\&isAllowed=y. Accessed 20 May 2020

Norton RM, vanderMark E (2016) Nitrogen performance indicators for southern Australian grain farms. Proceedings of the International Nitrogen Conference, (Ed J Angus), Melbourne Australia, December 2016. http://www.proceedings.com.au/nitrogen-performance-indicatorson-southern-australian-grain-farms/ [04 October 2020]

NPCT (2020) Nutrição de Plantas Ciência e Tecnologia. Av. Independência, 350, Sala 141A, Piracicaba, SP, BRASIL https://www.npct.com.br/npctweb/npct.nsf/article/calculadora. Accessed 20 May 2020

Öborn I, Edward AC, Witter E, Oenema O, Ivarsson K, Withers PJA, Nilsson SI, Stinzing AR (2003) Element balances as a tool for sustainable nutrient management: a critical appraisal of their merits and limitations within an agronomic and environmental context. Eur J Agron 20:211-225. https://doi.org/10.1016/S1161-0301(03)00080-7

OzDSM (2020) Australian Digital Soil Mapping. http://www.ozdsm.com.au/ozdsm_map.php. Accessed 20 May 2020

Pasuquin JM, Pampolino MF, Witt C, Dobermann A, Oberthür T, Fisher MJ, Inubushi K (2014) Closing yield gaps in maize production in Southeast Asia through site-specific nutrient management. Field Crop Res 156:219-230. https://doi.org/10.1016/j.fcr.2013.11.016

Patra AK, Dutta SK, Dey P, Majumdar K (2017) Potassium fertility status of Indian soils: national soil health card database highlights the increasing potassium deficit in soils. Indian J Fert 13 (11):28-33

Pérez Zamora (2015) La fetilización de la caña de azucar. In: Echeverría HE and García FO (eds) Fertilidad de suelos y fertilización de cultivos, ed. INTA. 2a. ed. Buenos Aires, Argentina, pp 609-630. ISBN: 9-789875-215658.

Regmi A, Ladha JK, Pasuquin E, Pathak H, Hobbs P, Shrestha L, Gharti D, Duveiller E (2002) The role of potassium in sustaining yields in a long-term rice-wheat experiment in the Indo-Gangetic Plains of Nepal. Biol Fert Soils 36:240-247. https://doi.org/10.1007/s00374-002-0525-x 
Roberts TR, Majumdar K (2017) Global P \& K use and balance in world agriculture. Indian J Fert 13(4):32-39

Sainz Rozas H, Eyherabide M, Echeverría HE, Barbieri P, Angelini H, Larrea GE, Ferraris GN, Barraco M (2013) ¿Cuál es el estado de la fertilidad de los suelos argentinos? In: Garcia F, Correndo A (eds) Symposio fertilidad 2013, IPNI Southern Cone-Fertilizar AC, Rosario, Argentina, pp 62-72. https://inta.gob.ar/documentos/_cual-es-el-estado-de-la-fertilidad-de-lossuelos-argentinos. Accessed 20 May 2020

Satyanarayana T, Tewatia RK (2009) State wise approaches to crop nutrient balances in India. In: Proceedings of the IPI-OUAT-IPNI international symposium on potassium role and benefits in improving nutrient management for food production, quality and reduced environmental damages, Bhubaneswar, Orissa, India, 5-7 Nov 2009, pp 467-485

Setiyono TD, Walters DT, Cassman KG, Witt C, Dobermann A (2010) Estimating maize nutrient uptake requirements. Field Crop Res 118(2):158-168. https://doi.org/10.1016/j.fcr.2010.05.006

Sheldrick WF, Syers JK, Lingard J (2003) Soil nutrient audits for China to estimate nutrient balances and output/input relationships. Agric Ecosyst Environ 94(3):341-354. https://doi. org/10.1016/S0167-8809(02)00038-5

Shen RP, Sun B, Zhao QG (2005) Spatial and temporal variability of N, P and K balances for agroecosystems in China. Pedosphere 15(3):347-355

Shepherd KD, Soule MJ (1998) Soil fertility management in west Kenya: dynamic simulation of productivity, profitability and sustainability at different resource endowment levels. Agr Ecosyst Environ 71(1-3):131-145. https://doi.org/10.1016/S0167-8809(98)00136-4

Singh M, Singh VP, Reddy DD (2002) Potassium balance and release kinetics under continuous rice-wheat cropping system in Vertisol. Field Crops Res 77:81-91. https://doi.org/10.1016/ S0378-4290(01)00206-4

Singh VK, Tiwari R, Gill MS, Sharma SK, Tiwari KN, Dwivedi BS, Shukla AK, Mishra PP (2008) Economic viability of site-specific nutrient management in rice-wheat cropping. Better Crops India 2:16-19

Singh VK, Dwivedi BS, Buresh RJ, Jat ML, Majumdar K, Gangwar B, Govil V, Singh SK (2013) Potassium fertilisation in rice-wheat system across northern India: crop performance and soil nutrients. Agron J 105(2):471-481. https://doi.org/10.2134/agronj2012.0226

Singh VK, Dwivedi BS, Tiwari KN, Majumdar K, Rani M, Singh SK, Timsina J (2014) Optimizing nutrient management strategies for rice-wheat system in the Indo-Gangetic Plains of India and adjacent region for higher productivity, nutrient use efficiency and profits. Field Crop Res 164:30-44. https://doi.org/10.1016/j.fcr.2014.05.007

Singh VK, Shukla AK, Dwivedi BS, Singh MP, Majumdar K, Kumar V, Mishra R, Rani M, Singh SK (2015a) Site-specific nutrient management under rice-based cropping systems in IndoGangetic Plains: yield, profit and apparent nutrient balance. Agric Res 4:365-377. https://doi. org/10.1007/s40003-015-0179-1

Singh VK, Shukla AK, Singh MP, Mujumdar K, Mishra RP, Rani M, Singh SK (2015b) Effect of site-specific nutrient management on yield, profit and apparent nutrient balance under pre-dominant cropping systems of Upper Gangetic Plains. Indian J Agric Sci 85:335-343

Singh VK, Dwivedi BS, Yadvinder-Singh SSK, Mishra RP, Shukla AK, Rathore SS, Shekhawat K, Majumdar K, Jat ML (2018) Effect of tillage and crop establishment, residue management and $\mathrm{K}$ fertilization on yield, $\mathrm{K}$ use efficiency and apparent $\mathrm{K}$ balance under rice maize system in north-western India. Field Crops Res 224:1-12. https://doi.org/10.1016/j.fcr.2018.04.012

Smaling EMA, Braun AR (1996) Soil fertility research in sub-Saharan Africa: new dimensions, new challenges. Commun Soil Sci Plan 27(3-4):365-386. https://doi.org/10.1080/ 00103629609369562

Stitou M (1985) Etude pédologique de la région de Settat et Ben Ahmed. Rapport du marché no. 46182/DPN42. DPA, Settat, Rabat

Stoorvogel JJ, Smaling EMA, Janssen BH (1993) Calculating soil nutrient balances in Africa at different scales. Fert Res 35(3):227-235. https://doi.org/10.1007/BF00750641 
Swift MJ, Frost PGH, Campbell BM, Hatton JC, Wilson KB (1989) Nitrogen cycling in farming systems derived from savanna: perspectives and challenges. In: Clarholm M, Bergström L (eds) Ecology of arable land-perspectives and challenges, Developments in plant and soil sciences, vol 39. Springer, Dordrecht, pp 63-76. https://doi.org/10.1007/978-94-009-1021-8_7

Tan DS, Jin JY, Jiang LH, Huang SW, Liu ZH (2012) Potassium assessment of grain producing soils in north China. Agr Ecosyst Environ 148:65-71. https://doi.org/10.1016/j.agee.2011.11. 016

Tandon HLS (2004) Fertilizers in Indian agriculture - from 20th to 21st century. Fertilizer Development and Consultation Organisation, New Delhi

Tarmizi AM, Mohd Tayeb D (2006) Nutrient demands of Tenera oil palm planted on inland soils of Malaysia. J Oil Palm Res 18:204-209. http://palmoilis.mpob.gov.my/publications/joprv18junetarmizi.pdf. Accessed 20 May 2020

Tewatia RK, Rattan RK, Bhende S, Kumar L (2017) Nutrient use and balances in India with special reference to phosphorus and potassium. Indian J Fert 13(4):20-29

Timsina J, Singh VK, Majumdar K (2013) Potassium management in rice-maize systems in South Asia. J Plant Nutr Soil Sci 176(3):317-330. https://doi.org/10.1002/jpln.201200253

Tittonell P, Vanlauwe B, Leffelaar PA, Rowe EC, Giller KE (2005) Exploring diversity in soil fertility management of smallholder farms in western Kenya. II. Within-farm variability in resource allocation, nutrient flows and soil fertility status. Agr Ecosyst Environ 110 (3-4):166-184. https://doi.org/10.1016/j.agee.2005.04.003

Tiwari KN, Dwivedi BS, Subba Rao A (1992) Potassium management in rice-wheat system. In: Pandey RK et al (eds) Rice-wheat cropping system: Proceedings of the rice-wheat workshop, Modipuram, Meerut. Project Directorate for Cropping Systems Research, Modipuram, Meerut, India, pp 93-114

Tiwari KN, Sharma SK, Singh VK., Dwivedi BS, Shukla AK (2006) Site-specific nutrient management for increasing crop productivity in India: results with rice-wheat and rice-rice system. PDCSR Modipuram and PPIC India Programme, Gurgaon, pp. 92

Trelo-ges V, Limpinuntana V, Patanothai A (2004) Nutrient balances and sustainability of sugarcane fields in a mini-watershed agroecosystem of Northeast Thailand. Southeast Asian Stud 41 (4) : 4 73-490. ht tp s://pd f s. se mantics cholar.org/c $154 /$ 3228177ddfb17d998d1458761c3a7dc6faa2.pdf?_ga=2.40050337.2057332575.1576787027249372282.1576787027. Accessed 20 May 2020

USDA FAS (2017) Production, supply and distribution database. United States Department of Agriculture Foreign Agriculture Service. https://apps.fas.usda.gov/psdonline/app/index.html\#I app/home. Accessed 20 May 2020

Van den Bosch H, de Jager A, Vlaming J (1998) Monitoring nutrient flows and economic performance in African farming systems (NUTMON): II. Tool development. Agr Ecosyst Environ 71(1-3):49-62. https://doi.org/10.1016/S0167-8809(98)00131-5

Vanlauwe B, Diels J, Lyasse O, Aihou K, Iwuafor ENO, Sanginga N, Merckx R, Deckers J (2002) Fertility status of soils of the derived savanna and northern Guinea savanna and response to major plant nutrients, as influenced by soil type and land use management. Nutr Cycl Agroecosyst 62:139-150. https://doi.org/10.1023/A:1015531123854

Wang HJ, Huang B, Shi XZ, Darilek JL, Yu DS, Sun WX, Zhao YC, Chang Q, Öborn I (2008) Major nutrient balances in small-scale vegetable farming systems in peri-urban areas in China. Nutr Cycl Agroecosyst 81(3):203-218. https://doi.org/10.1007/s10705-007-9157-8

Wang XL, Feng AP, Wang Q, Wu CQ, Liu Z, Ma ZS, Wei XF (2014) Spatial variability of the nutrient balance and related NPSP risk analysis for agro-ecosystems in China in 2010. Agric Ecosyst Environ 193:42-52. https://doi.org/10.1016/j.agee.2014.04.027

Wihardjaka A, Kirk GJD, Abdulrachman S, Mamaril CP (1999) Potassium balances in rainfed lowland rice on a light-textured soil. Field Crop Res 64(3):237-247. https://doi.org/10.1016/ S0378-4290(99)00045-3 
Wingeyer AB, Amado TJC, Pérez-Bidegain M, Studdert GA, Varela CHP, García FO, Karlen DL (2015) Soil quality impacts of current South American agricultural practices. Sustainability 7 (2):2213-2242. https://doi.org/10.3390/su7022213

Yadav RL, Prasad K, Gangwar KS (1998) Prospects of Indian agriculture with special reference to nutrient management under irrigated systems. In: Swarup A et al (eds) Long term fertilizer management through integrated plant nutrient supply. Indian Institute of Soil Science, Bhopal, India, pp 1-325

Yadvinder-Singh, Bijay-Singh, Ladha JK, Khind CS, Khera TS, Bueno CS (2004) Effects of residue decomposition on productivity and soil fertility in rice-wheat rotation. Soil Sci Soc Am J 68:854-864. https://doi.org/10.2136/sssaj2004.8540

Yadvinder-Singh, Bijay-Singh, Timsina J (2005) Crop residue management for nutrient cycling and improving soil productivity in rice-based cropping systems in the tropics. Adv Agron 85:269-407. https://doi.org/10.1016/S0065-2113(04)85006-5

Yamada T, Lopes AS (1998) Nutrient budget in Brazilian agriculture. Informações Agronômicas 84:1-8. (In Portuguese). https://www.npct.com.br/publication/ia-brasil.nsf/issue/BRS-1998-84. Accessed 20 May 2020

Zerouali M, Mrini M (2004) Fertilité des sols et fertilisation potassique des principales cultures dans la region du Gharb (Maroc): développement de la fertigation. In: Badraoui M, Bouabid R, Ait-Houssa A (eds) International Potash Institute (IPI) regional workshop on potassium and fertigation development in west Asia and north Africa; Rabat, Morocco, 24-28 Nov 2004, pp 1-9. https://www.ipipotash.org/uploads/udocs/Fertilite\%20des\%20Sols\%20et\%20Fertilisation \%20Potassique\%20des.pdf. Accessed 20 May 2020

Zhang HM, Xu MG, Shi XJ, Li ZH, Huang QH, Wang XJ (2010) Rice yield, potassium uptake and apparent balance under long-term fertilization in rice-based cropping systems in southern China. Nutr Cycl Agroecosyst 88(3):341-349. https://doi.org/10.1007/s10705-010-9359-3

Zhang X, Davidson EA, Mauzerall DL, Searchinger TD (2015) Managing nitrogen for sustainable development. Nature 528:51-57. https://doi.org/10.1038/nature15743

Zingore S, Murwira HK, Delve RJ, Giller KE (2007) Influence of nutrient management strategies on variability of soil fertility, crop yields and nutrient balances on smallholder farms in Zimbabwe. Agric Ecosyst Environ 119:112-126. https://doi.org/10.1016/j.agee.2006.06.019

Open Access This chapter is licensed under the terms of the Creative Commons Attribution 4.0 International License (http://creativecommons.org/licenses/by/4.0/), which permits use, sharing, adaptation, distribution and reproduction in any medium or format, as long as you give appropriate credit to the original author(s) and the source, provide a link to the Creative Commons license and indicate if changes were made.

The images or other third party material in this chapter are included in the chapter's Creative Commons license, unless indicated otherwise in a credit line to the material. If material is not included in the chapter's Creative Commons license and your intended use is not permitted by statutory regulation or exceeds the permitted use, you will need to obtain permission directly from the copyright holder.

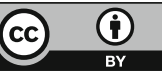

